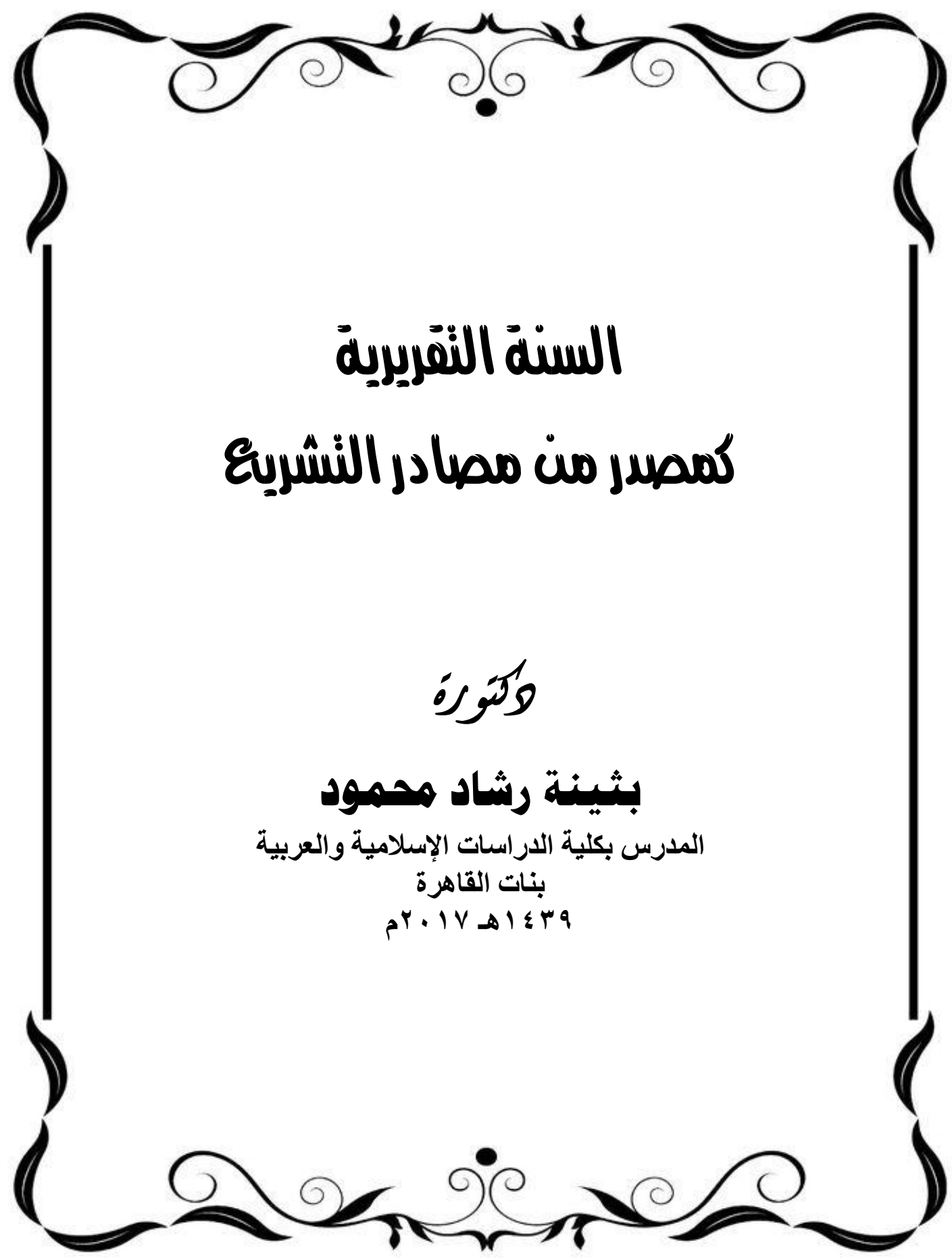



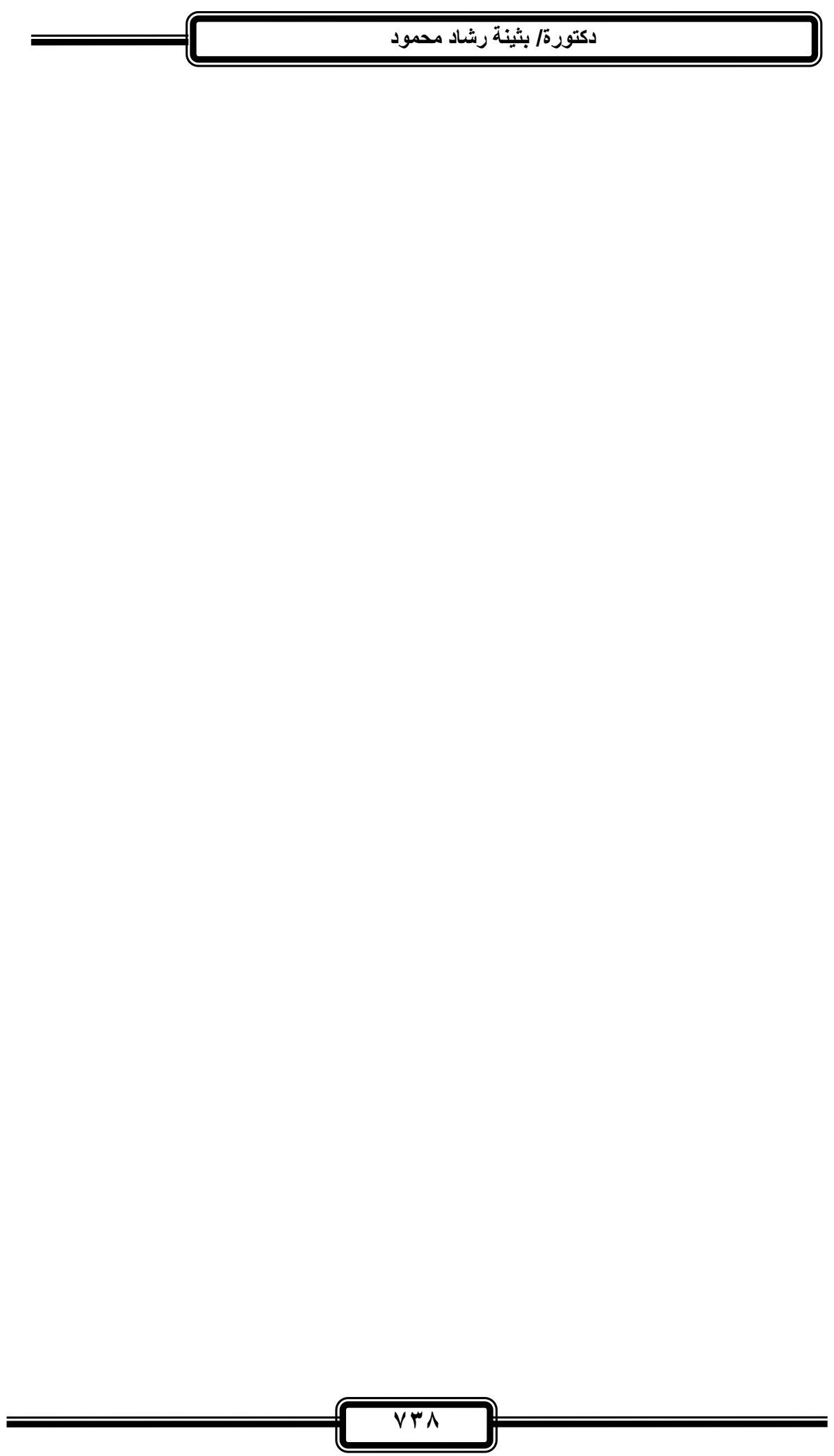

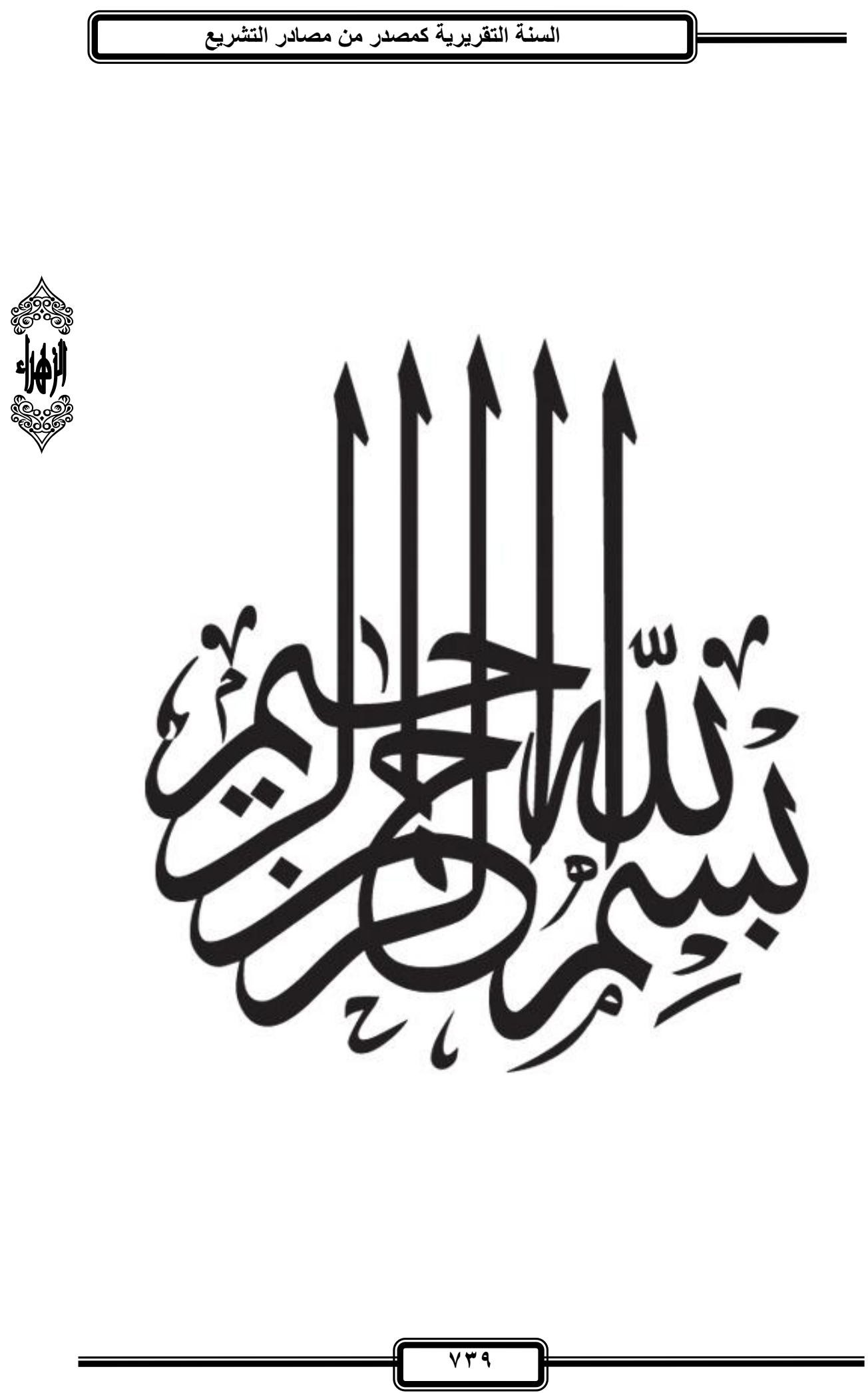

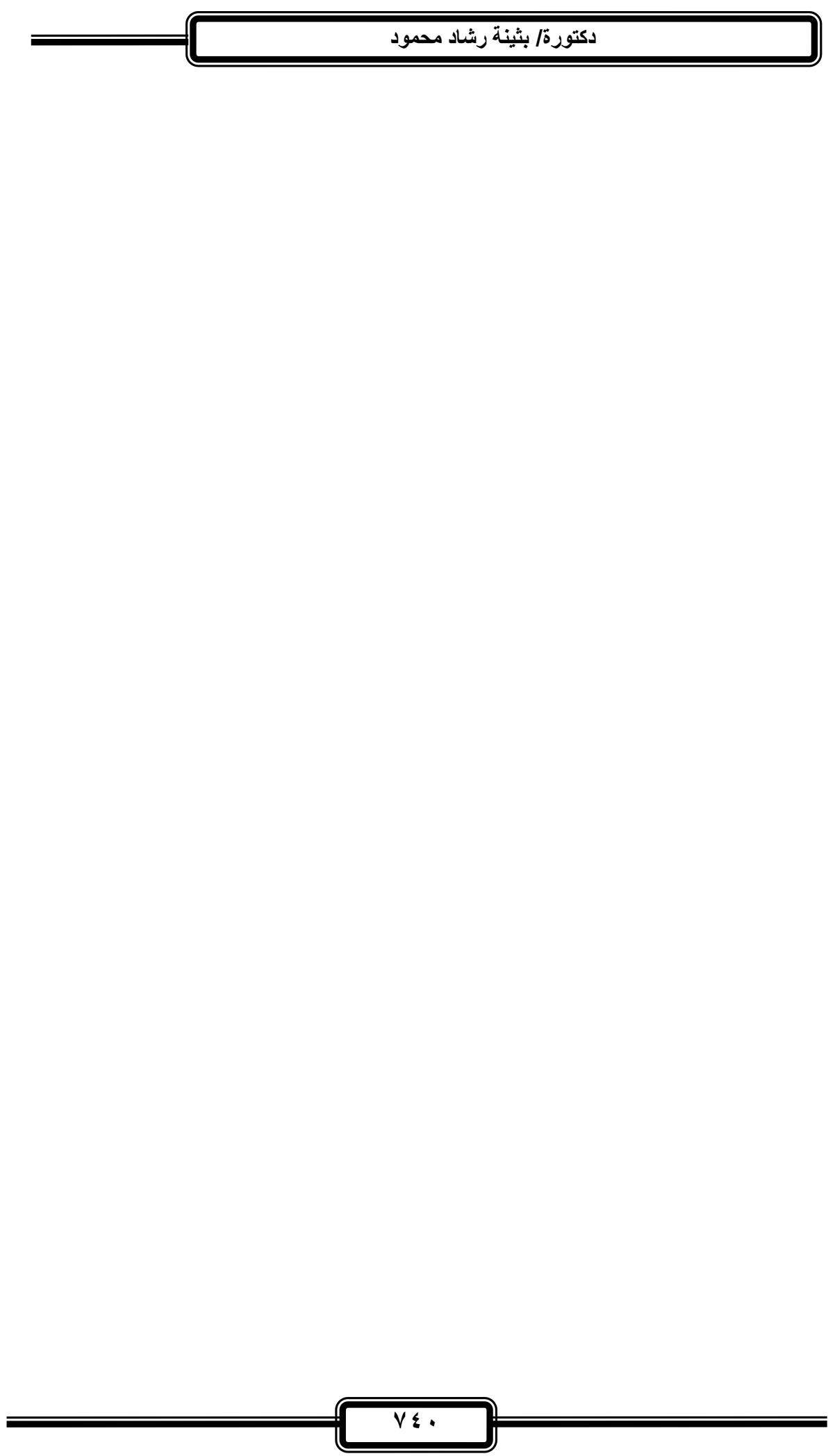


\section{قال تعالى}

\section{\} يا أيها الناس قد جاعمم برهان من ريكم وأنزلنا إليكم نوراً مبينا}

سورة النساء آية \} V V 

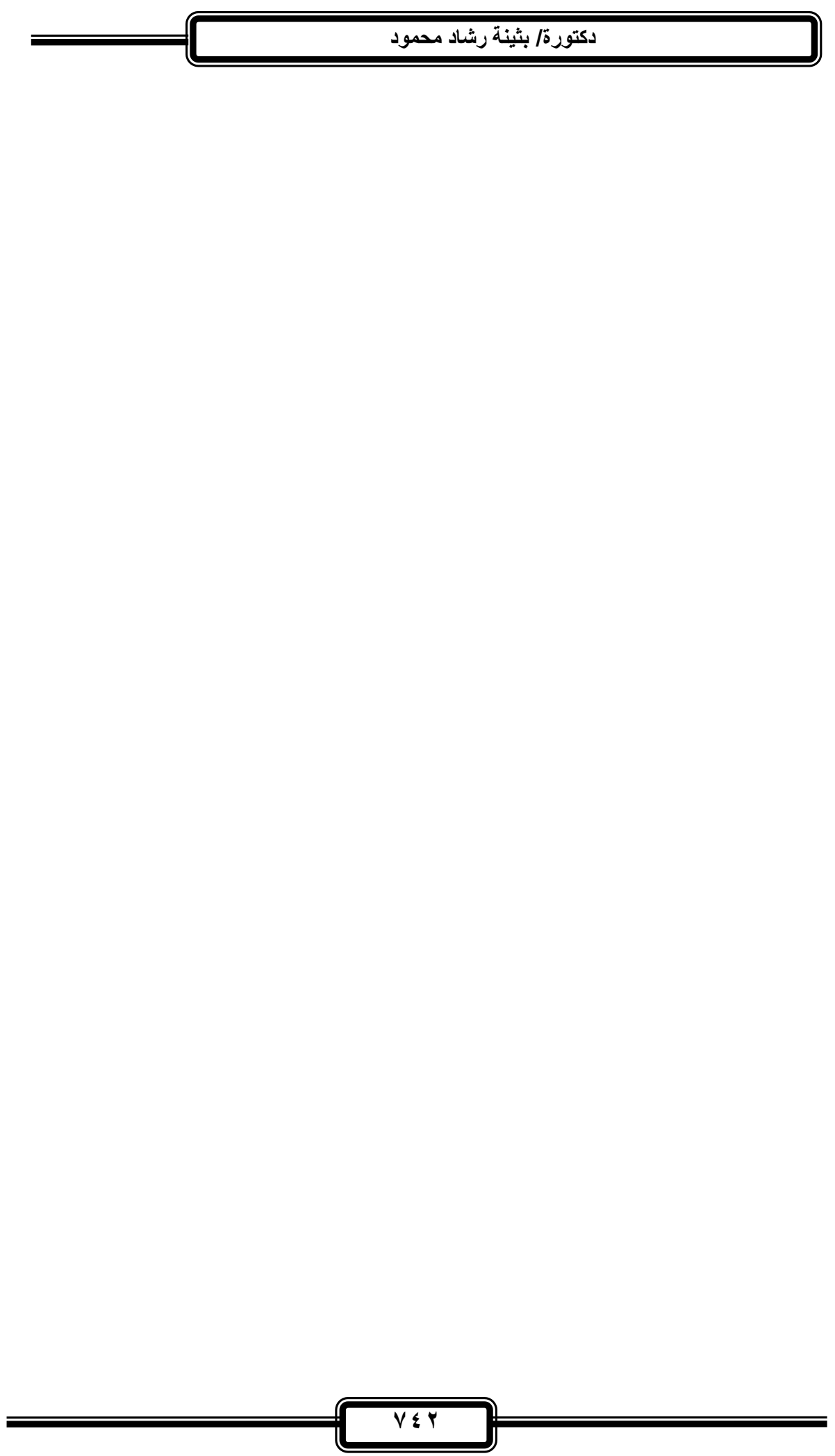


\section{السنة التقزيرية كمصدر من مصادر التشريع}

\section{المقدهة}

الحمد لله الذي رفع بالعلم درجات أهله وأجزل ثوابهم على اكتسـابه ونقله كمـا أنعم عليهم بـالتوفيق لارسـه وحملهـه ، والصـلاة والسـلام على سيلنا محمد خاتم أنبيائه ورسله الذي بلغخ الرسـالة بقولـه وفعله وتقريره ، ويذل جهده في إقامة دين الحق وبيان أصله وفرعه حتى ظهر مصداقاً لقوله تعـالى \}هو الذي أرسـل رسـوله بالهدى وديـ الحق ليظهره على الدين كلـه|(') صل الله عليه وعلى آله وصـبه ومن تبعهم بإحسـان إلى يوم • الدين

\section{ويعد}

فإنه من المعلوم للقاصي واللداني أن السنة المطهرة هي المصدر الثاني من مصادر التشريع وأنها تثقسم إلى السنة القولية والسنة الفعلية والسنة التقريرية وأريا هنا أن ألقي الضوء على السنة التقريرية ومـا ذاك إلا لأن الناظر في المؤلفات الأصولية ق لا يجد ما يروي ظمأه في هذا الموضوع حيث لا يوجد مؤلف أصولي -على حد علمي- تكلم عن السنة التقريريـة كدراسة مستقلة مفصلة فقد تجد بعضاً منه في ثنايا الكلام وقد لا تجد مما دفعني إلى البحث في هذا الموضـوع لبيـان معنى التقريـر ، وهل هنـاك شروط لاعتبار التقريز صحيحاً أم لا ؟ وما هي صوره ؟ وهل كل مـا سكت

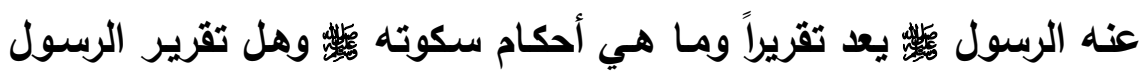

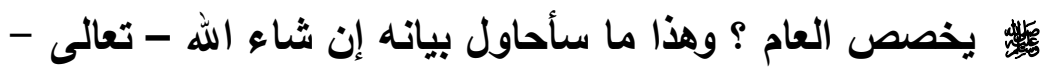

\{Y^\} (1 ) سورة الفتح من الآية 

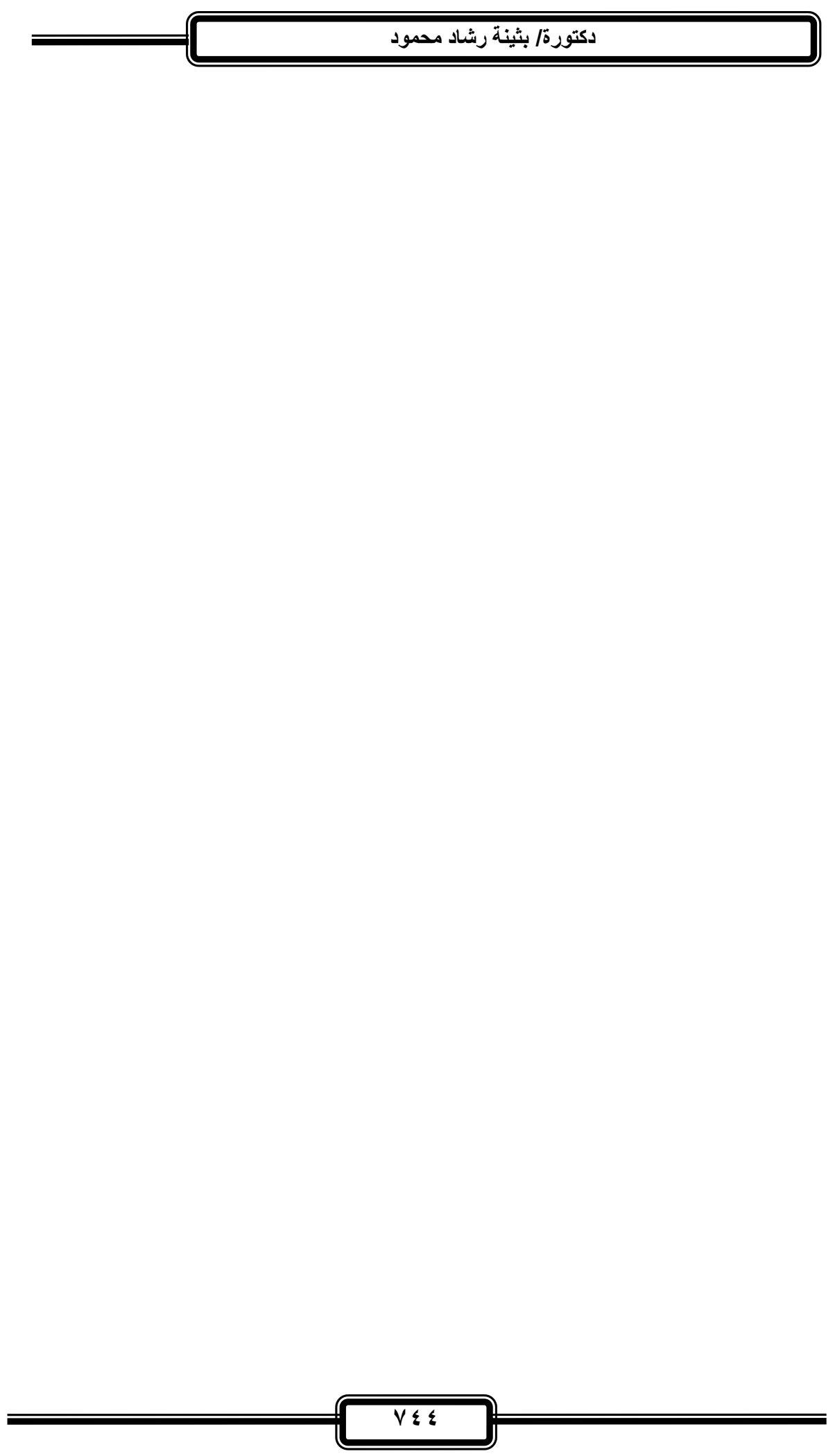
خطة البحث

$$
\text { المبحث الأول تعريف التقرير }
$$

المبحث الثاني محل الاتفاق ومحل الاختلاف

المبحث الثالث شروط حجية التقرير

المبحث الرابع صور التقرير

المبحث الخامس أحكام سكوته

المبحث السادس : التخصيص بالتقريز

المبحث السابع : ثمرة الخلاف 


\section{دكتورة/ بثينة رشاد محمود}

\section{المبحث الأول}

معنى تقرير النبي

لما كان الحكم على الثيء فرع عن تصوره كان لابد أولاً من بيان مغنى

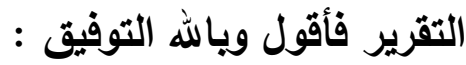

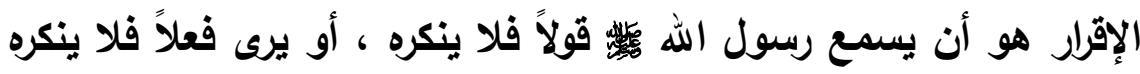

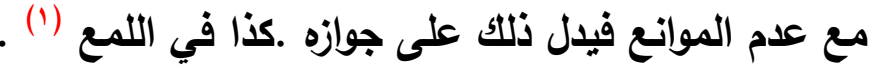

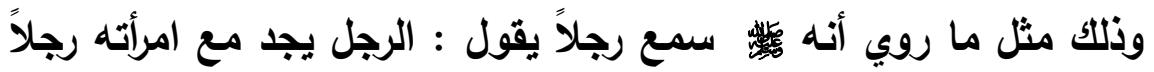

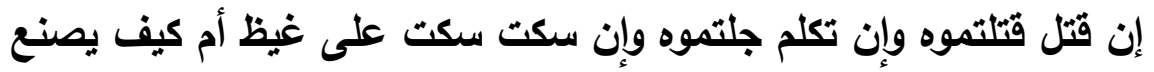

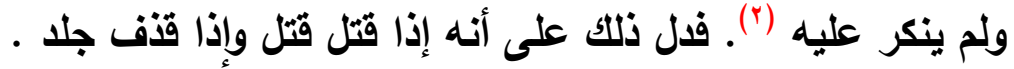

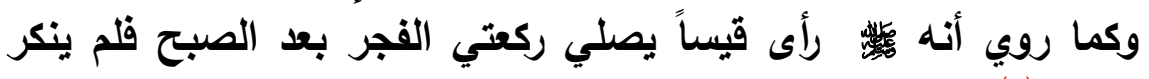

(") عليه

فدل على جواز الصلاة التي لها سبب بعد الصبح - وهو ما قاله الثافعية

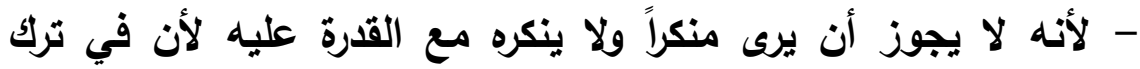

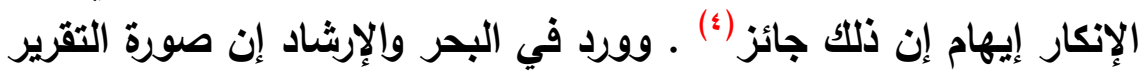

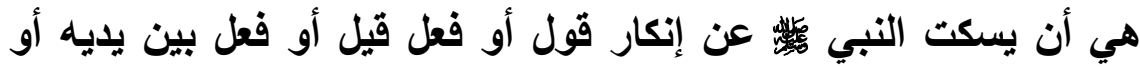

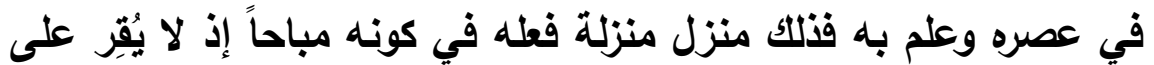

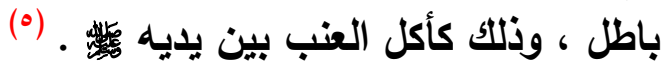

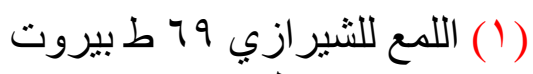

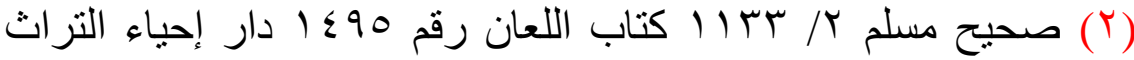

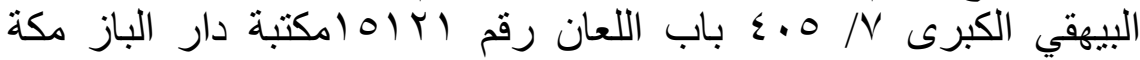

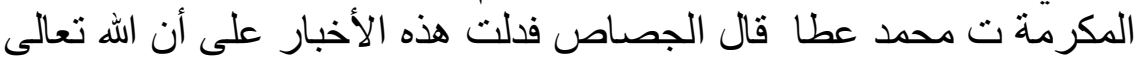

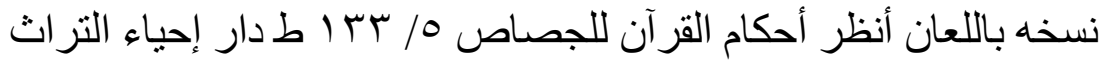

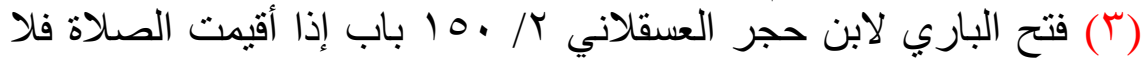

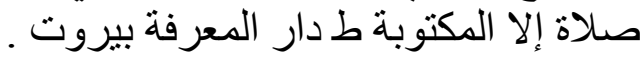

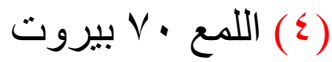

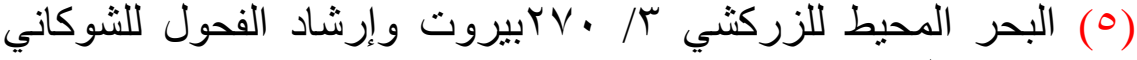

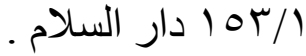




\section{السنة التقريرية كمصدر من مصادر التثريع}

\section{المبحث الثاني \\ محل الاتفاق ومحل الاختلاف \\ أولاً : محل الاتفقق}

اتفق على أن التقرير هو أن يراهم : أو أو بعضهم يفعل الفعل ، أو يخبر

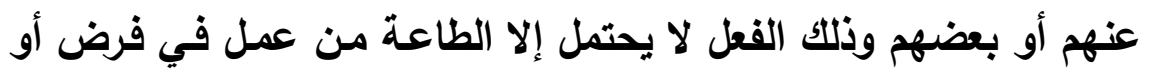

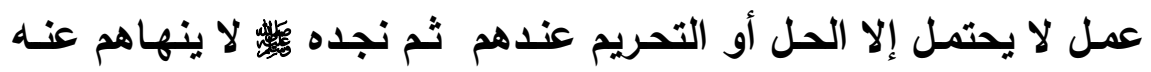

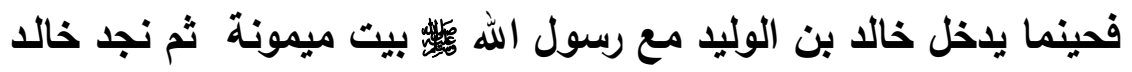

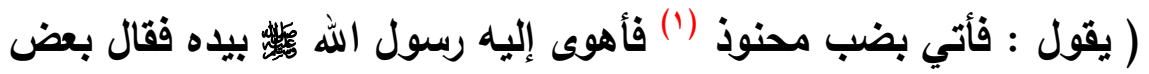
النسوة اخبروا رسول الله بما يريد أن يأكل فقالوا : هو ضب يالي رسول الهول الله

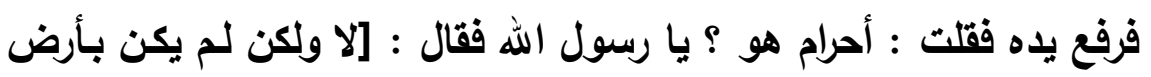

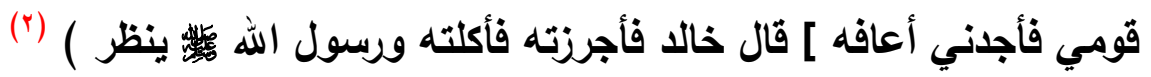

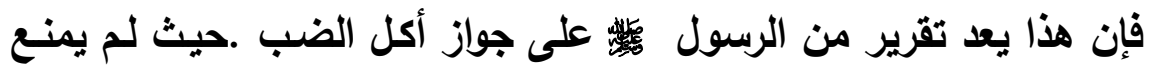
خالا من الأكل من الضب .وعلى ذلك فإن هذا الحديث يعد من السنة

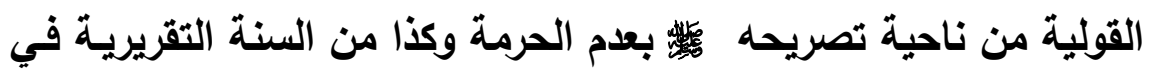
كونه ترك خالا يأكل دون أن يمنعه .

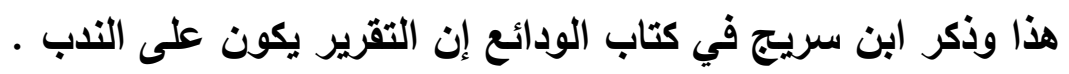

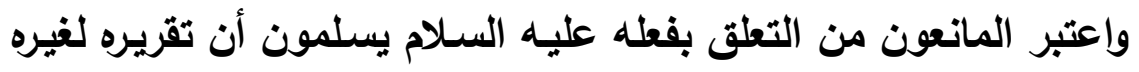

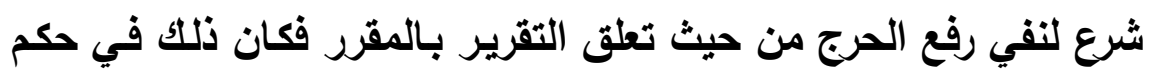

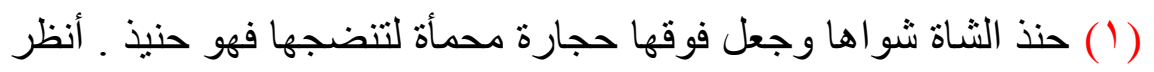
القاموس المحيط للفيروزآبادي مادة حنذ ط دار الفكر ومختار الصحاح 77

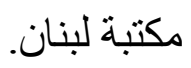

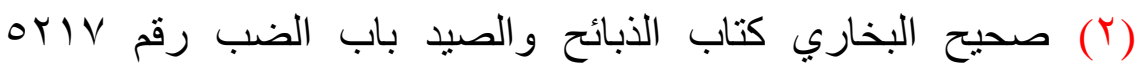

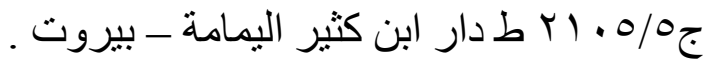


الخطـاب برفـع الحـرج وهــا ممـا لا خـلاف فيـه كمـا قـال ابـن القشـيري

وغيره. (1)

ثانياً : محل الاختلاف :

اختلفوا في أمرين : الأمر الأول :إذا دل التقريز على انتفاء الحرج فهل يختص بمن قرر؟ أو يعم سائر المكلقين ؟ ذهب القاضي إلى الأول وهو أن التقرير يختص بمن قرر ؛ وذلك لأن التقرير ليس له صيخة تعم ، ولا يتعدى إلى غيره إلا أن ينعقد الإجماع على أن التحريم إذا ارتفع في حق لقى واحد ارتفع في حق الكافة .

وذهب إمام الحرمين إلى الثاني وهو أن بعم سائر المكلفين وهو الأظهر؛ لأنا بينا أنه في حكم الخطاب وقد تقرر أن خطاب الواحد خطاب للجميع

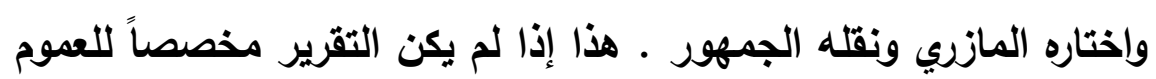
المتقلم ، فإن كان كذلك ، فاختلفوا فيه أيضاً (؟) واختار الآمدي أنه إن فأن بيّن لألك الفعل معنى يقتضى جواز مخالفة ذلك الواحد للعموم ، فإنه

يتعدى إلى كل من وجد فيه ذلك المعنى بالقياس على ما قرر () وقال الرازي : إن ثبث أن حكمه عليه السلام في الواحد حكمه في الكل

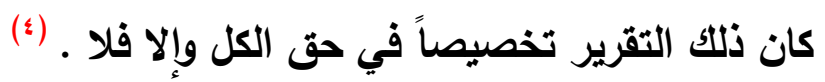

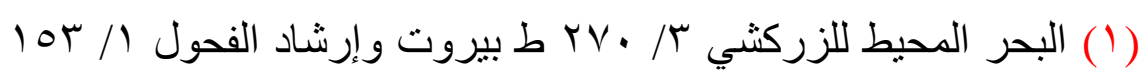

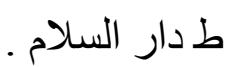

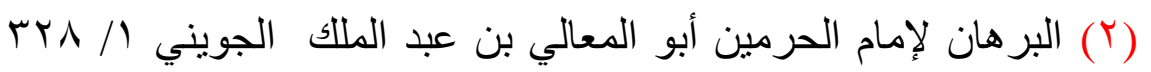

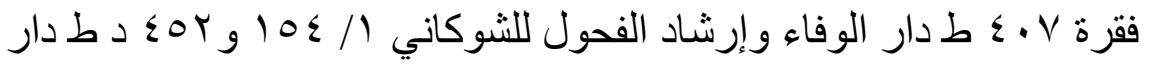

$$
\begin{aligned}
& \text { السلام ت د شعبان محمد اسماعيل . }
\end{aligned}
$$

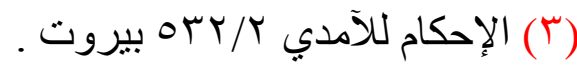

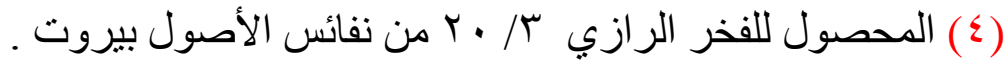




\section{السنة التقريرية كمصدر من مصادر التشريع}

وقال القرافي إن كلام الرازي عليه سؤالان :

الأول : إنه علق على كلمة " إن " ما هو معلوم لأنه ل كرر حكماً في حق شخص فهو للأمة . أله الثاني : أن كلامه يفضي إلى النست فإذا خرج الكل أي شيء يبقى في النص فيكون نسخاً فيفضي تقرير النسخ إلى إبطاله إلا أن يحمل على إنى

(') (التأويل . (1)

واختار ابن الحاجب عند فهم المعنى قطع الإلحاق والاختصاص بمن قرر فقط . واختار جماعة التعدي إلى الكل . وقد صرح جمع من الأصوليين بأن الفعل إذا سبق تحريمه فيبقى تقريره

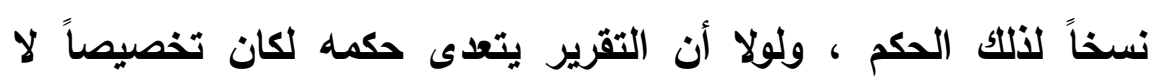
نسخاً، وقد نص الشافعي على أن تقرير النبي عليه الصلاة والسلام

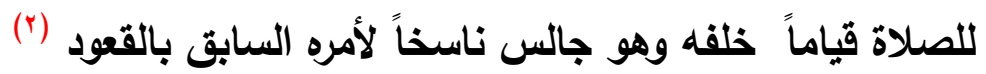
الأمر الثاني :

إذا تضمن رفع الحرج إما خاصاً أو عاماً فهل يحمل على الإباحة أو لا

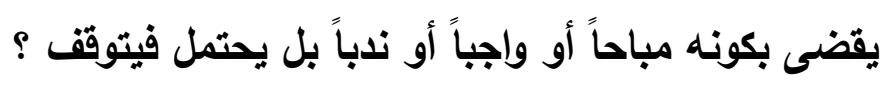
فذهب القاضي إلى الثاني ، بينما ذهب ابن القشيري إلى الأول وذلك لأنه

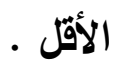

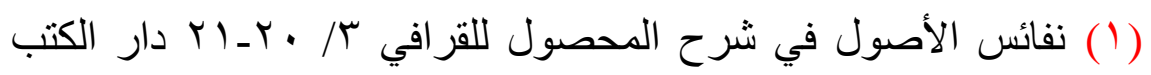

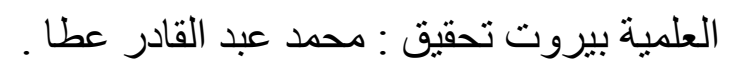

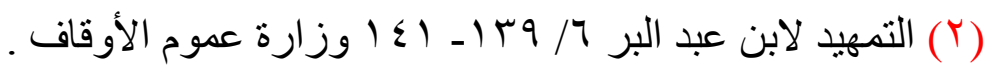




\section{دكتورة/ بثينة رشاد محمود}

وإذا قلنا بالإباحة وهو المشهور ، فاختلفوا في حم الاستباحة لما أقر

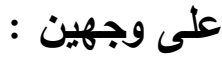
حكاهما إلكيا والماوردي : والروياني . الوجه الأول : أنه مباح بالأصل المتقلم ، وهو براعة الأمة ، فلا ينتقل إلا بسبب ، وهذا منهم من تعلق باستصحاب الحال .

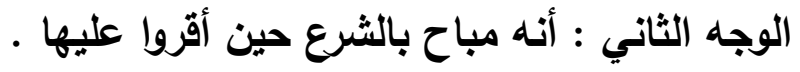

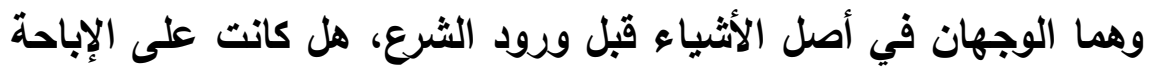
حتى حظرها الثارع أو على الحظر حتى أباحها ؟

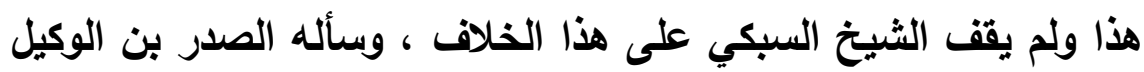

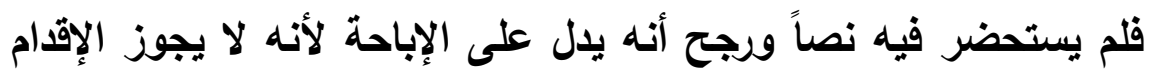
على فعل حتى يعرف حكمه

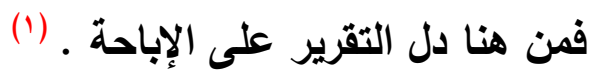

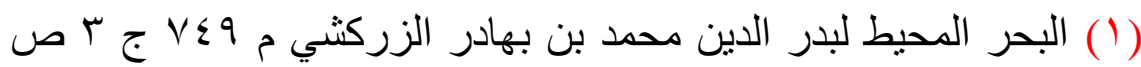

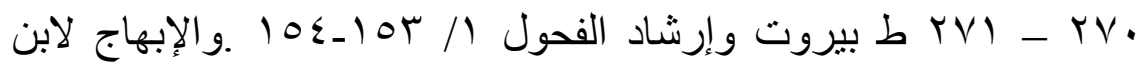

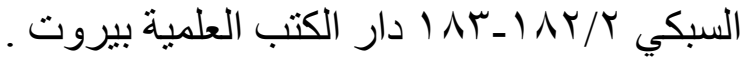




\section{السنة التقريرية كمصدر من مصادر التثريع}

\section{المبحث الثالث : شروط حمية التقرير}

اثتترط الأصوليين عدة شروط لابد من توافرها حتى يكون التقرير حجة

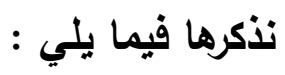

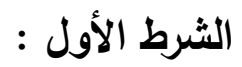

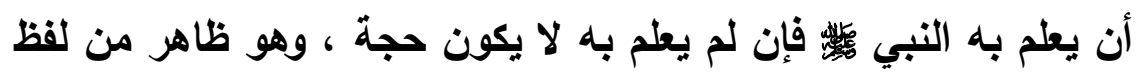

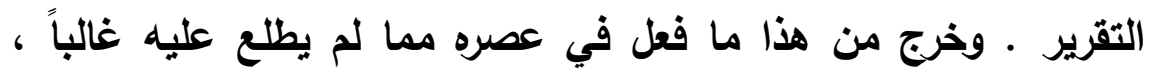
كقولهم : كنا نجامع ونكسل (1) وما فعل في عهله عليه فئ السلام ، ولم يعلم

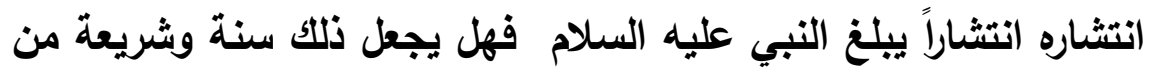
شرائعه

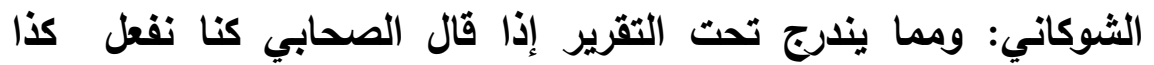

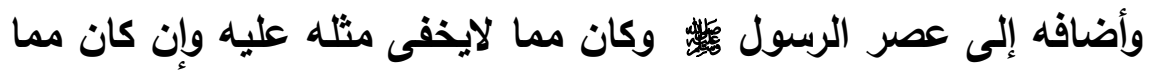
يخفى مثله عليه فلا . (") وأطلق الآمدي وابن الحاجب والصفي الهندي أن الأكثرين على أنه حجة

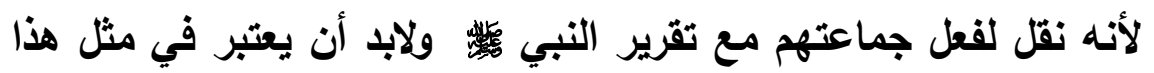

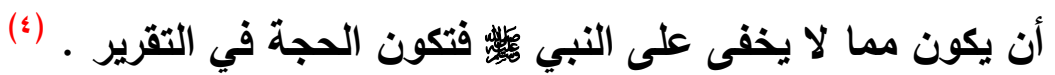

(1) عون المعبود لمحمد شمس الحق العظيم آبادي / / ror باب الإكسال

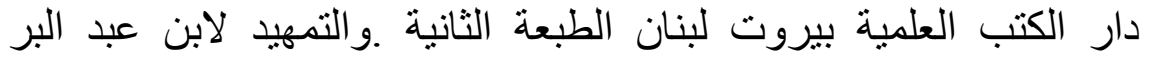

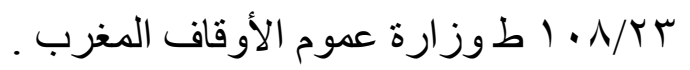

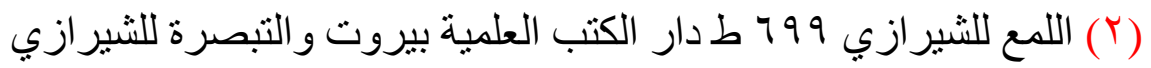

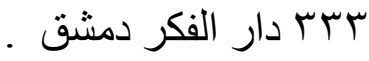

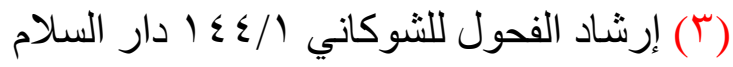

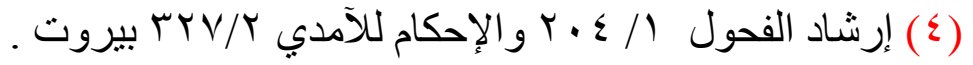




\section{دكتورة/ بثينة رشاد محمود}

وقال الأستاذ أبو إسحاق الإسفراييني في شرح الترتيب : اختلف قول الثافعي فيه

ولهذا قال في الأقط (') هل يجوز في زكاة الفطر أم لا ؟ على قولين .

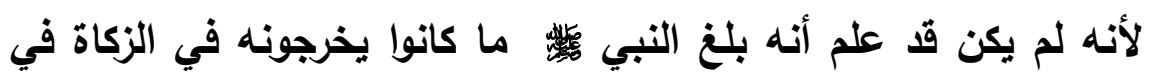

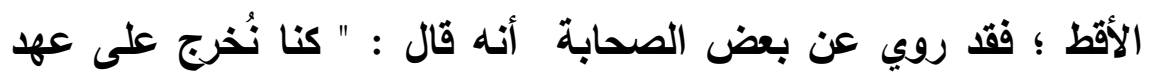

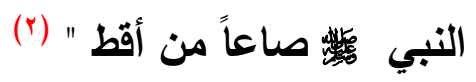
وقال ابن السمعاني: إذا قال الصحابي : كانوا يفطلون كذا وأضافه إلى إنى عصر النبي

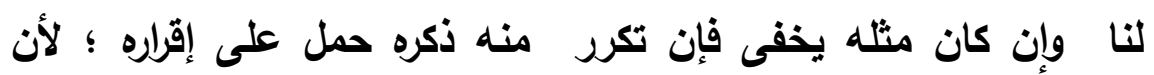

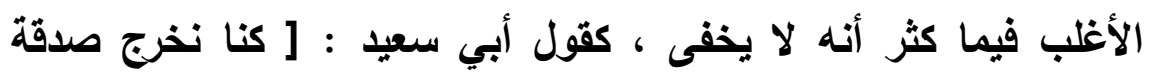

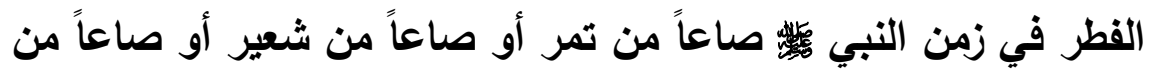

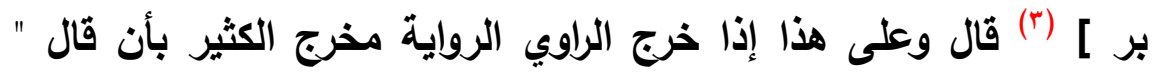
كانوا يفطلون كذا " المال

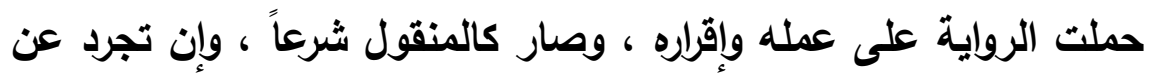
لفظ التكثير كقوله : " فعلوا كذا " فهو محتمل ولا يثبت شرع باحتمال .

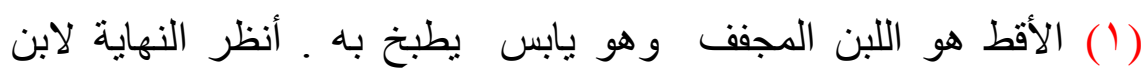

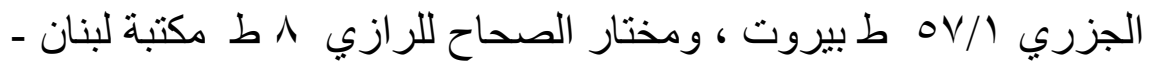

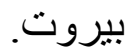

(Y) شرح النووي على صحيح مسلم باب زكاة الفطر \/•T دار إحياء

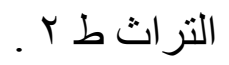

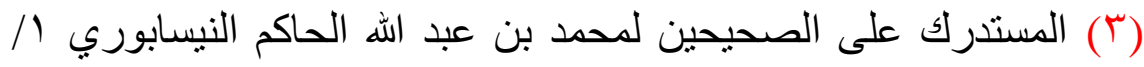

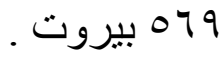




\section{السنة الثقريرية كمدر من مصادر الثثريع}

قال الثبرازي في التبصرة : (') إن هذا كالمسند إلى رسول الله وقدال وقال بعض أصحاب أبي حنيفة ليس كالمسند . ودليلنا هو أن الظاهر من حال الصحابة أن لا يقدموا على أمر من أمور

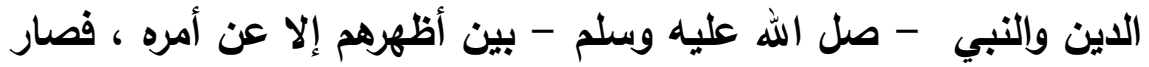
ذلك كالمسند إليه .

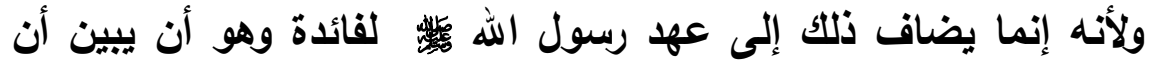
النبي

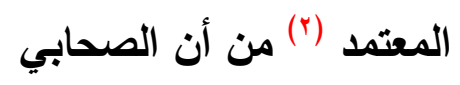
هنا قصد أن يطلمنا حكماً ويفيدنا شرعاً ، ولا يكون كنلك إلا وقت كانوا يفطون على وجه يظهز له فلا ينكره ولهذا كان الظاهر من قول الراوي كانوا يفعلون كذا وكذا ، هو أن جماعة الأمة كانوا يفعلون ذلك أو يفعل

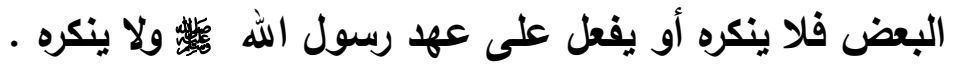

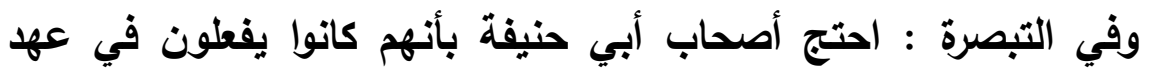

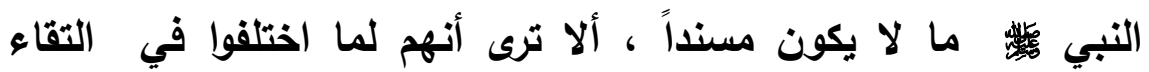
الختانين بغير إنزال لما قال بعضهم كنا نجامع على عهر رسول الله

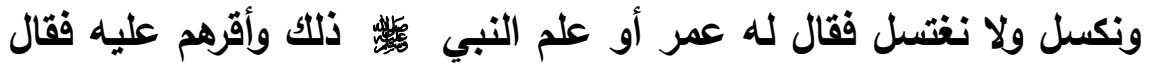

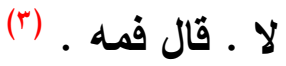

(1) التبصرة للثيرازي بساطط دار الفكر .

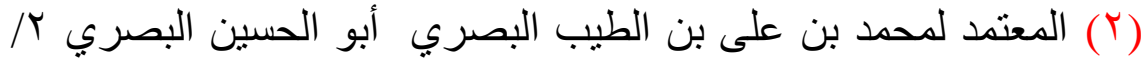

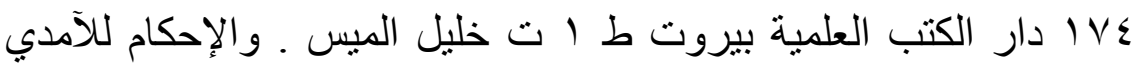

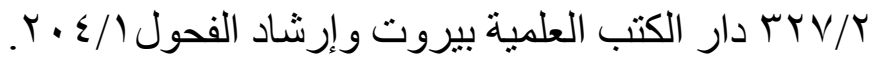

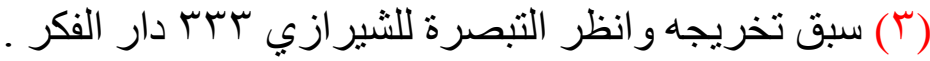


وقال جابر كنا نبيع أمهات الأولاد على عهد التبي (1)

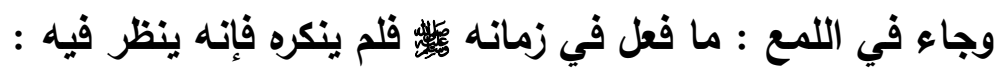
فإن كان ذلك مما لا يجوز أن يخفى عليه من طريق العادة كان بمنزلة

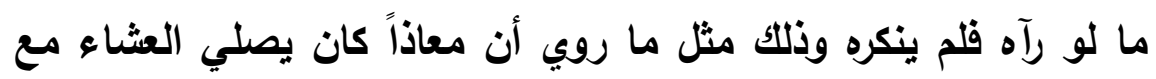

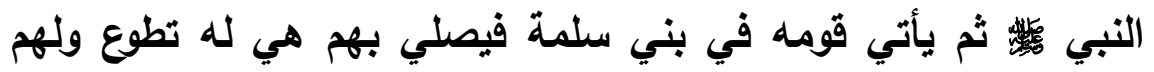

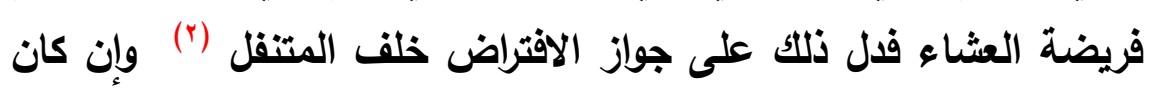
مثل ذلك لا يجوز أن يخفى عليه ، فإن كان لا يجوز لأنكر

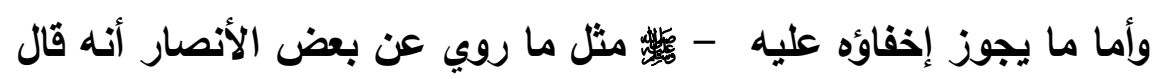

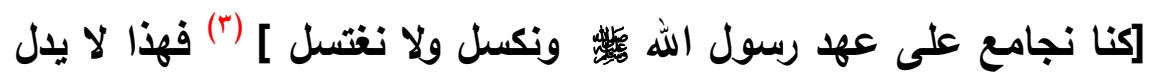
على الحكم لأن ذلك يفعل سراً ويجوز أن لا يعلم به رسول الله يغتسلون لأن الأصل أن لا يجب الغسل فلا يحتج به في إسقاط الغسل . (؛) وأضاف في التبصرة : أما التقاء الختانين فما كان يجب به الغسل في ابتداء الإسلام وكانوا يجامعون ولا يغتسلون ثم نسخ ذلك في زمن النبي

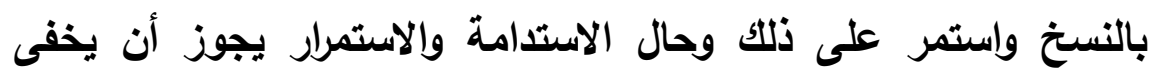

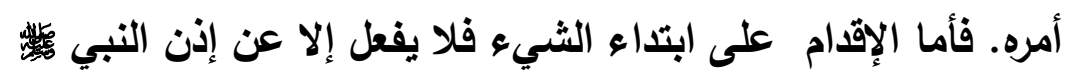

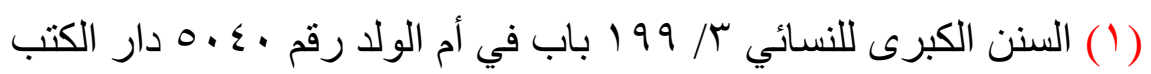

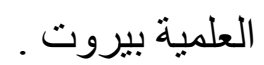
(r) اللمع للثير ازي 79 بيروت و اختلاف الحديث للشافعي 000 ط مؤسسة

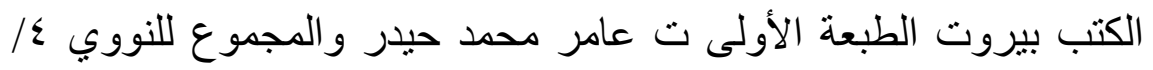

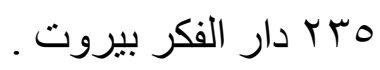

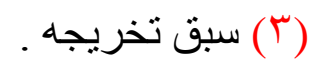

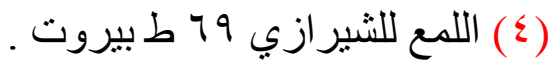




\section{السنة التقريرية كمصدر من مصادر التثريع}

وأما حديث جابر فالمراد به أمهات الأولاد في غير ملك اليمين وهو أن يتزوج جارية لهم وذلك جائز . (1)

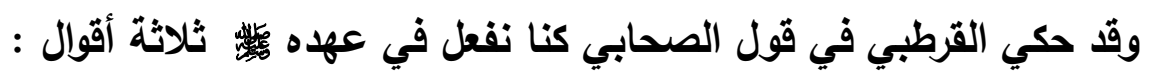

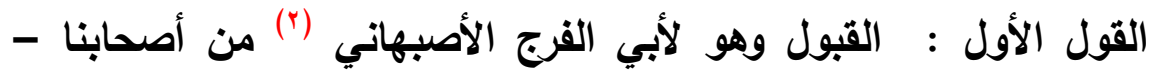

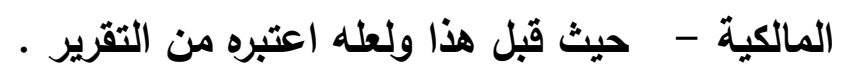

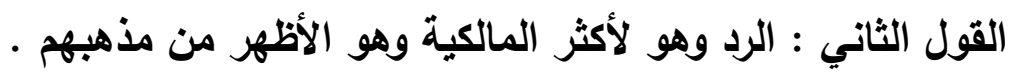

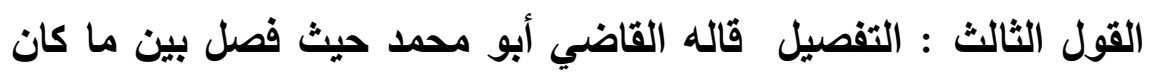

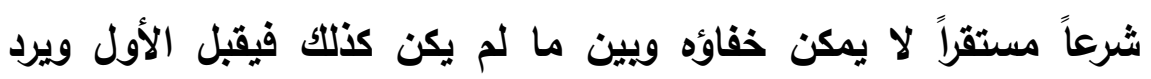
الثاني.

ومثال الأول : قول أبي سعيد [ كنا نخرج صدقة عيد الفطر على عهد رسول الله خفاؤه عليه

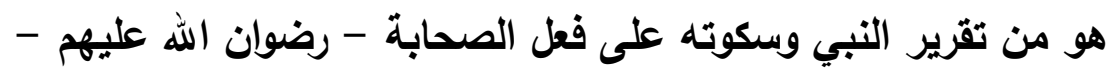

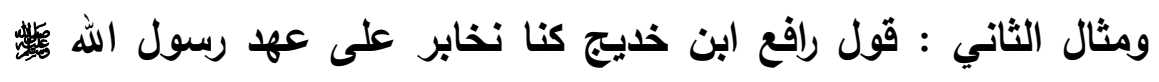

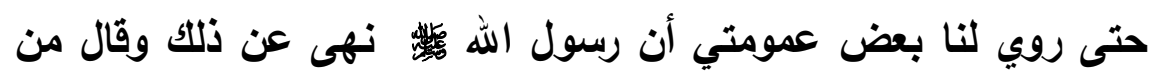

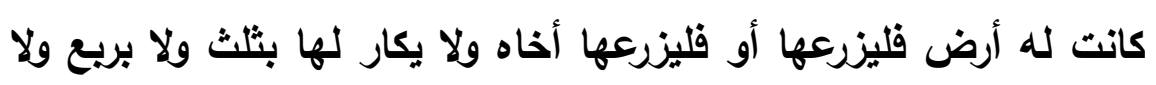

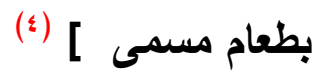

$$
\text { (1) التبصرة للثيرازي سمسط دار الفكر . (1) }
$$

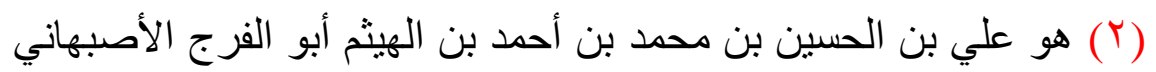

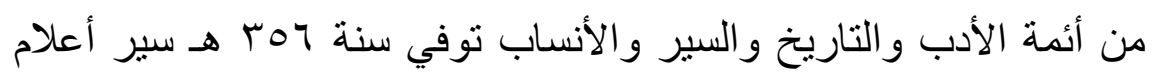

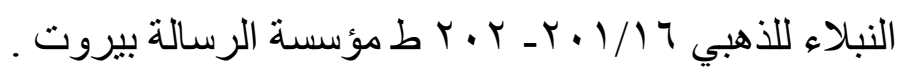

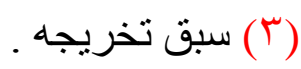

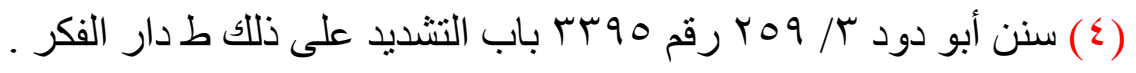


ورجح هذا التفيل الثيخ أبو اسحق الثيرازي وقيل إن ذكر الصحابي ذللك في معرض الحجة حمل على الرفع وإلا فلا. وأما لو قال الصحابي : كانوا يفعلون أو كنا نفعل ، ولا يقول على عهل اله

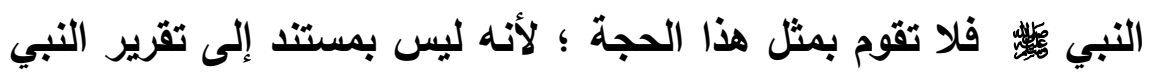

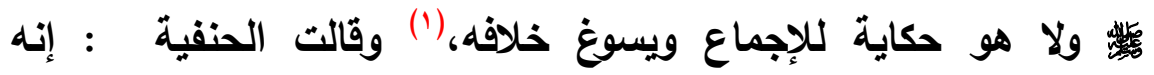
إجماع. (r)

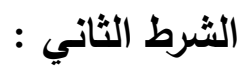
أن يكون قادراً على الإنكار كذا قال ابن الحاجب وغيره وفيه نظر . فقد ذكر الفقهاء من خصائصه عدم سقوط وجوب تغيير المنكر بالخوف على النفس وعدم السقوط في الحقيقة ؛ لأنه لا يقع منه خوف على نفسه بعد إخبار الله بعصمته في قوله تعالى \}والله يعصمك من الناس قال القاضي أبو الطيب في تعليقه : وإنما اختص عليه السلام بوجويه لأمرين : أحدهما : أن الله ضمن له النصر والظفر بقوله سبحانه \} إنا كفيناك المستهزئين ج(؛) الثاني : أنه لو لم ينكره لكان يوهم أن ذلك جائز، وإلا لأمر بتركه وحينئ فلا يعقل اشتراط هذا الثرط ـ (•) الشرط الثالث : الثر :

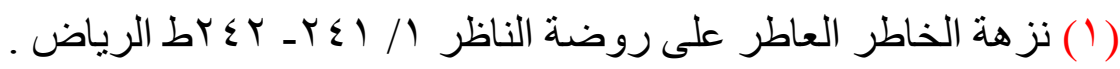

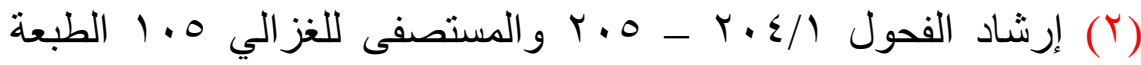
الأولى دار الكتب العلمية بيروت ت محمد عبد السلام عبد الثافي .

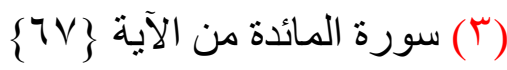
\{0

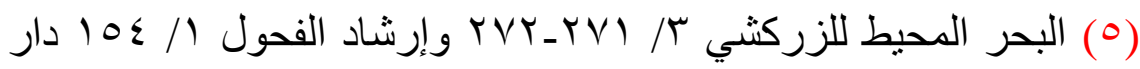


كون المقر على الفعل منقاداً للشرع سامعاً مطيعاً ، فالمتتع كالكافر لا

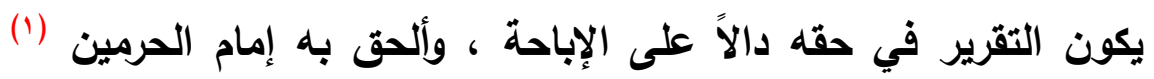

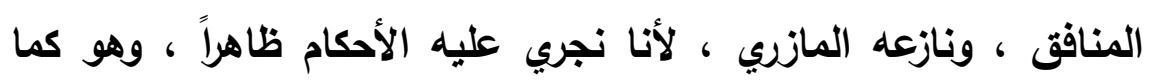

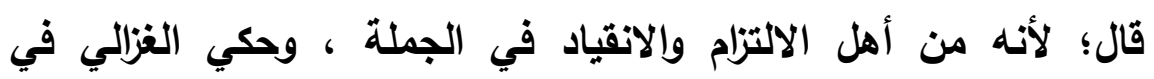

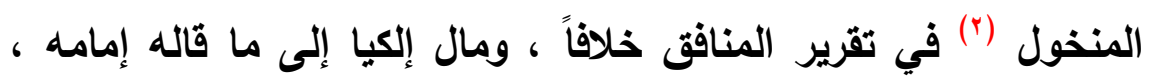

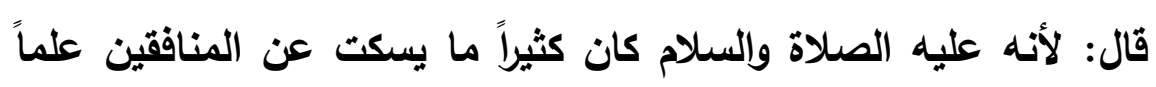
منه أن العظة لا تنفع معهم ، وإن كان العذاب حقيقاً بهم . الثرط الرابع :

فقد شرط ابن أبي هريرة في تعليقه كون التقرير بعد ثبوت الثرع أما ما

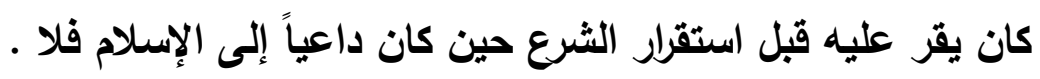
الثرط الخامس :

وهو لابن السمعاني حيث اشترط أن لا يتقلم تقريره إنكار سابق قال :

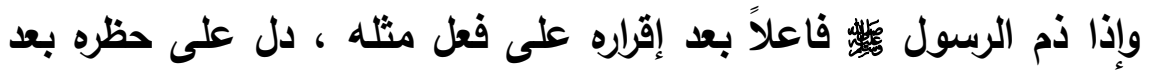

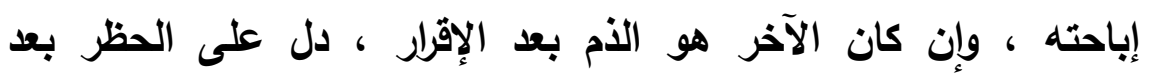

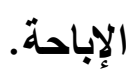

وقال : إذا علم من حال مرتكب المنكر إن الإنكار عليه يزيدة إغراءً على مثله :

فإن علم به غير الرسول لم يجب عليه الإنكار ؛ لئلا يزداد من المنكر

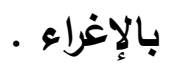
وإن علم به الرسول ففي إنكاره وجهان :

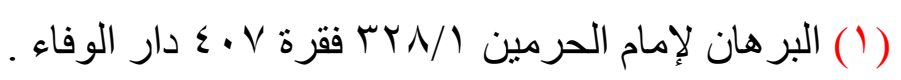

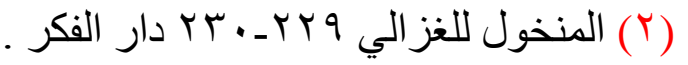


أحدهما : لا يجب لما ذكر وهو قول المعتزلة . الثاني : يجب إنكاره ليزول بالإنكار توهم الإباحة .وهذا الوجه أظهر وهو الأشعرية وعليه يكون الرسول مخالفاً لغيره ، لأن الإباحة والحظر شرع

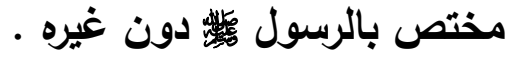

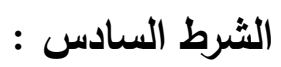
شرط ابن القشيري أن لا نجد للسكوت محملاً سوى التقرير ورفع الحرج فلو كان مشتغلاً ببيان حكم مستغرقاً فيه ، فرأى إنساناً على أمر ولم يتعرض له ، فلا يكون تركه ذلك تقريراً إذ لا يمكنه تقرير جميع الموانع بمرة واحدة .

قال ولهزا أقول ليس كل ما كان عليه الناس في صدر الشرع ، ثم تغير الأمر لا ياعى فيه النسخ ، بل إذا ثبث حكم شرعي ، ثم تغير فهو النستخ،

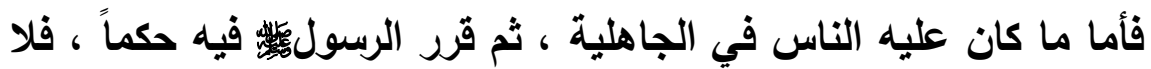
يقال : كان ذلك المتقدم شرعاً مستمراً ثم نسخ ، إذ ريما لم يتفرغ الرسول

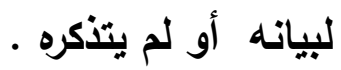
مثاله : قول الخصم في نكاح المشركات : كان قـ تقرر في ابتاء الإسلام انتفاء الحظر في المنكوحات ، ثم طرأ الحظر ، فنسخ ذلك الحكم ، وهذا مجازفة؛ إذ من الممكن أنهم كانوا يفعلون ولم يكن ذلك شرعاً ، بل جرياً على حكم ،

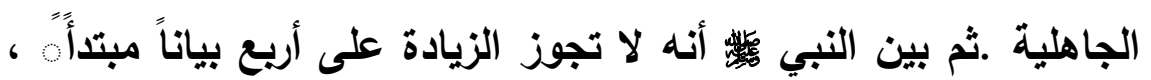
وأما إذا أمكن أن يكون سكوته محمولاً على أن جبريل -عليه السلام - لم يبين له بعد ذلك الحكم ، لم يقطع بمشروعية ذلك التقرير ، بل يقال 


\section{السنة التقريرية كمصدر من مصادر التثريع}

بانتفاء الحكم إذ لا عثور فيه على شرع ؛ وذلك لاندراس الشرائع

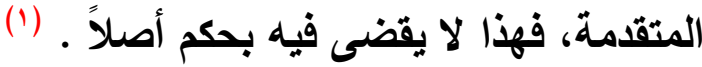

الشرط السابع : الش

أن لا يعلم من الفاعل اعتقاده ذلك الفعل كتردد اليهود إلى كنائسهم ، فإن سكوته

عن ذلك لا يقتضي إباحته للعلم بتقريز أهل الأمة على ذلك . (ץ) الشرط الثامن : الثر

اشترط للتقرير أن لا يعارضه التصريح بمعنى أنه لا يكون هناك تصريح

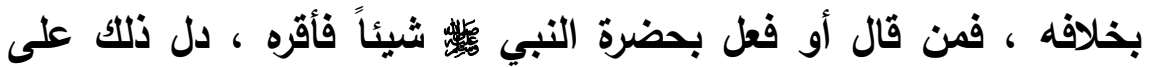
الجواز ، فإن صرح التبي التقريز إلا أن يثبت دليل الخصوصية ومثال ذلك : ما ورد من أن محمد بن المنكدر قال [رأيت جابر بن عبد الله يحلف بالله أن ابن صياد هو الاجال قلت تحلف بالله قال إني سمعت عمر

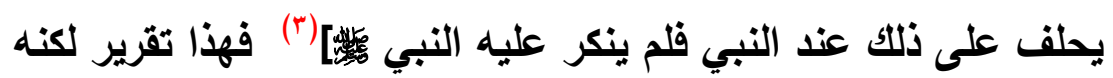
عارضه تصريح فقد قال ابن بطال بعد أن قرر دليل جابر.

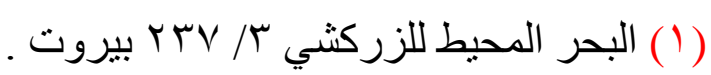

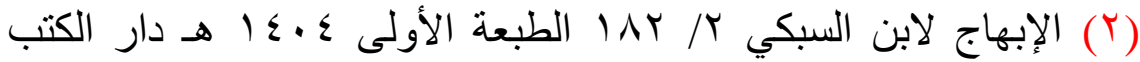

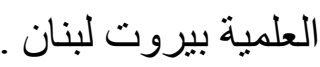

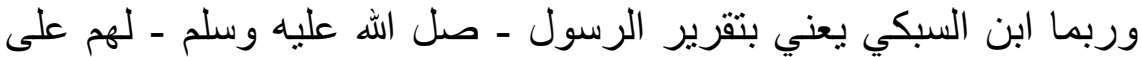

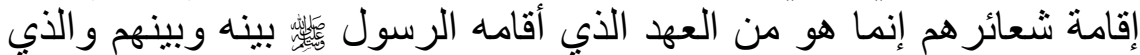

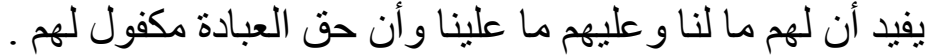

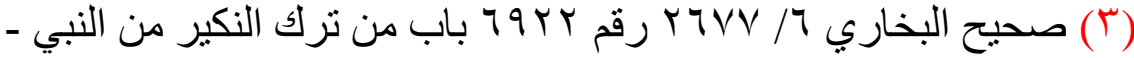

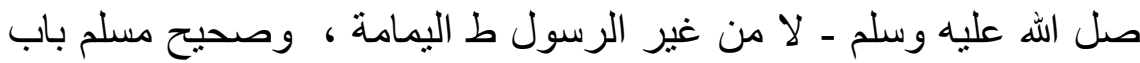

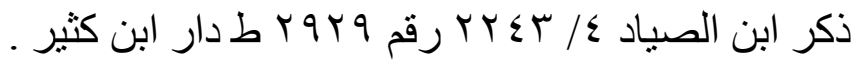




\section{دكتورة/ بثينة رشاد محمود}

فإن قيل : تقلم أن عمر قال للنبي عنقه فقال :

إن يكن هو فلن تشلط عليه ] (1) فهذا تصريح في أنه تردد في أمره فلا يدل سكوته على إنكاره عند حلف لف لف عمر على أنه هو الاجال . أجيب بجوابين : أبر

الأول : أن التردد قبل أن يعلمه الله أنه هو الاجال فلما أعلمه لم ينكر على عمر الحلف الثاني : أن العرب قد تخرج الكلام مخرج الثك

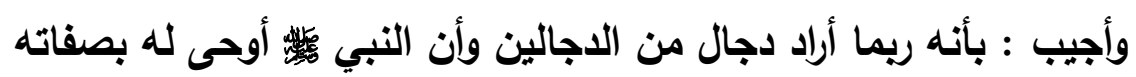
فأخبر عن صفاته وقت خروجه آخر الزمان ، وكان في ابن صياد قرائن محتملة ولذا كان

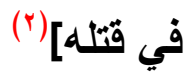

( ) فتح الباري لابن حجر العسقلاني r/Tr/T دار المعرفة ، و انظر نيل الأوطار للشوكاني N/ V/ دار الجيل ، والأحكام لابن حزم الظاهري

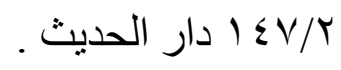

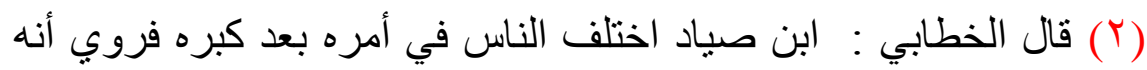

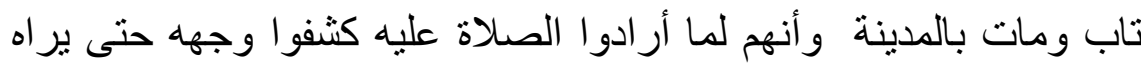

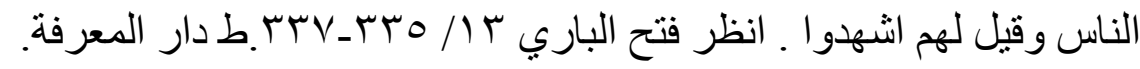




\section{السنة التقريرية كمصدر من مصادر التشريع}

\section{المبحث الرابع}

صور التقرير

الصورة الأولى : - الصف

أن يخبر النبي ويحتاج إلى معرفة حكم من الأحكام ،هل هو من لوازم ذلك الفعل ؟ فإذا

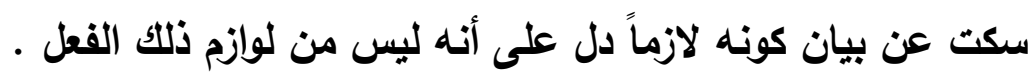
وذلك كما لو أخبر بإتلاف يحتاج إلى معرفة تعلق الضمان أو عدمـه ، كإتلاف خمر الأمي مثلاً ، فسكوته يدل على عدم تعلق الضمان به .

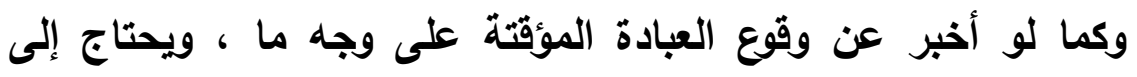
معرفة حكم القضاء بالنسبة إليها فإذا لم يبينه دل على وجوب القضاء . الصورة الثانية : أن يسأل عن قول أو فعل ، لا يلزم من سكوته عليه مفسدة في نفس الأمر لكن قد يكون ظن الفاعل أو القائل يقضي أن تترتب عليه مفسدة على تقديم امتناعه .

فهل يكون هذا السكوت دليلاً على الجواز بناءً على ظن المتكلم أم لا ؟ لأنه لا يلزم منه مفسدة في نفس الأمر،ومثال ذلك طلاق الملاعن وهو العجلاني حيث طلق زوجته ثلاث تطليقات بعد فراغهما من اللعان فأنفذه رسول الله النكاح، فيقضي ظنه بكون المفسدة واقعة على تقدير امتناع الإرسال ، هذا إذا ظهر للمتلاعنين والحاضرين عقب طلاقه أن الفرقة وقعت باللعان،

( (1) مختصر اختلاف العلماء للجصاص أحمد بن محمد بن سلامة الطحاوي

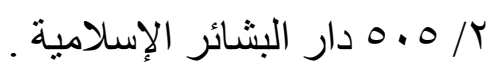


وإلا فيكون البيان واجباً لمفسدة الوقوع في الإرسال لذا لما ظن الزوج أن اللعان لا يحرمها ، أراد تحريمها بالطلاق فقال هي طالق ثلاثاً فقال له له

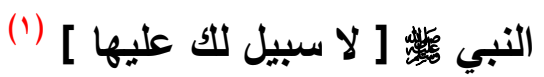

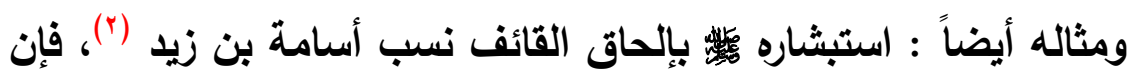
الأين لا يعتبرون إلحاق القائف يعتذرون بأن الإلحاق مفسدة في صورة الاشتباه ، ونسب أسامة لاحق بالفراش في حكم الشرع فلا تتحقق المفسدة عندهم في نفس الأمر ، لكن لما كان الطاعنون في النسبة اعتقدوا أن إلحاق القافة صحيح ، اقتضى ذلك الظن منهم مع ثبوت النسب شرعاً اشتراط عدم المفسدة في إلحاق القائف . الصورة الثالثة :

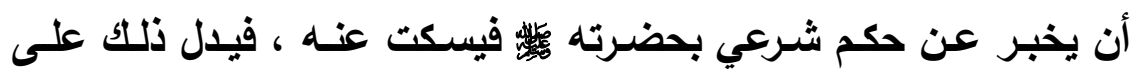
الحكم كمـا لو قيل بحضرته هذا الفعل واجب أو محظور إلى غيرهـا من - الأحكام

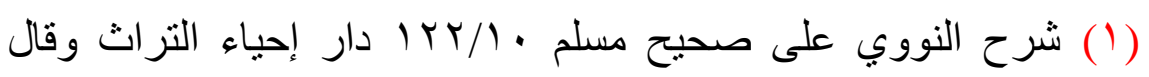
الجصاص فطلقها العجلاني ثلاث تطليقات بعد فر اغهما من اللعان فأنفذه

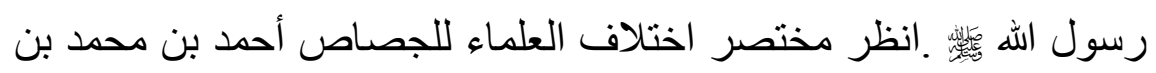

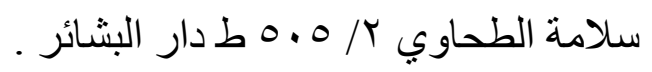

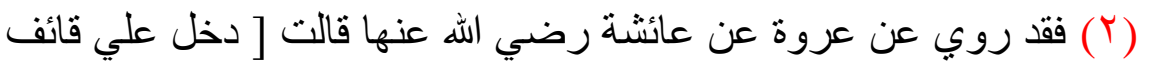

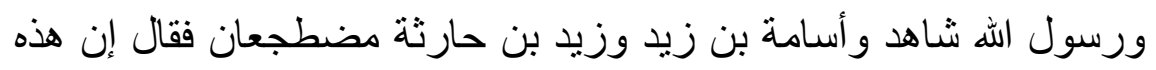

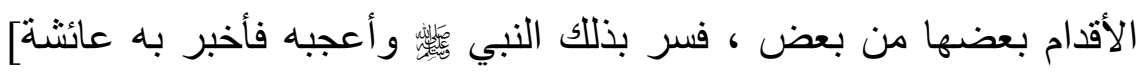

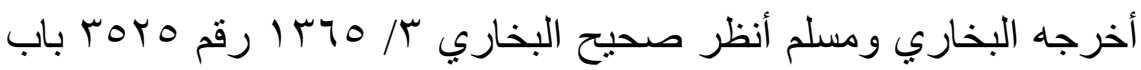

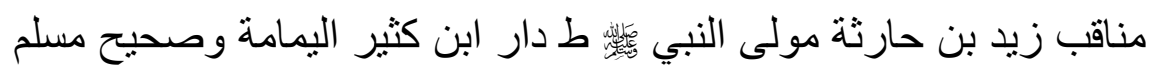

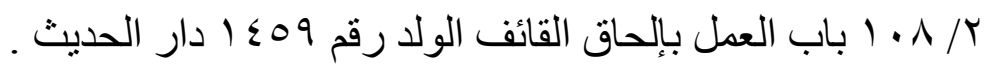




\section{السنة التقريرية كمصدر من مصادر التشريع}

الصورة الرابعة :

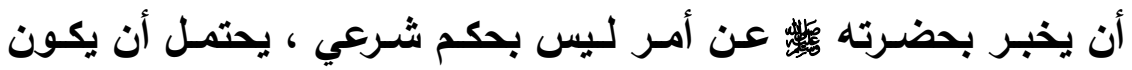

مطابقاً وأن لان

يكون فهل يكون سكوته دليلاً على مطابقته ؟ وذللك كحلف عمر بحضرته

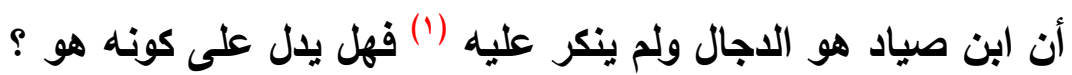
وفي ترجمة بعض أهل الحديث ما يشعر بأنه ذهب إلى ذلك . وعقب الشيخ ابن دقيق العيد في شرح الإلمام فقال:

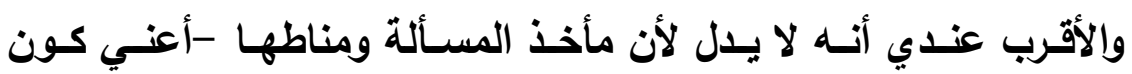
التقرير حجة - هو العصمة من التقرير على باطل ، وذلك يتوقف على هلى تحقق البطلان ، ولا يكفي فيه تحقق العصمة ، نعم التقرير يذل على جواز اليمين على حسب الظن وأنها لا تتوقف على العلم لأن عمر حلف على حسب ظنه ، وأقره عليه . الصورة الخامسة :

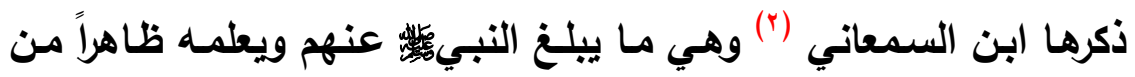
حالهم وتقرر عنده مـن عـاداتهم ممـا سـبيله الانتشـار والاثـتهار ، فـلا يتعرض لله بنكير كنوم الصحابة قعوداً ينتظرون الصلاة فلا يأمرهم بتجديد

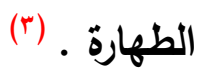

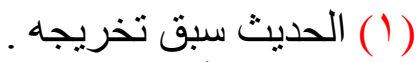

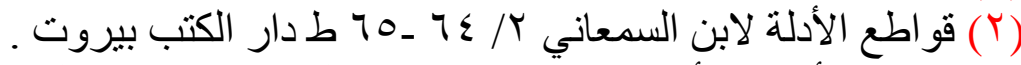

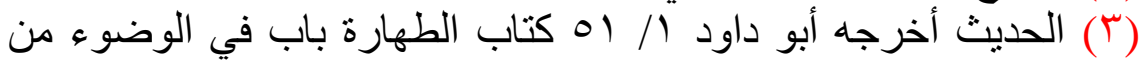

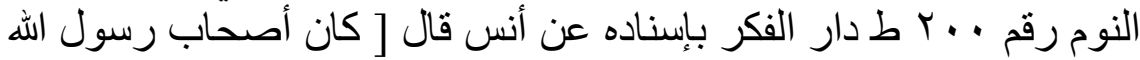

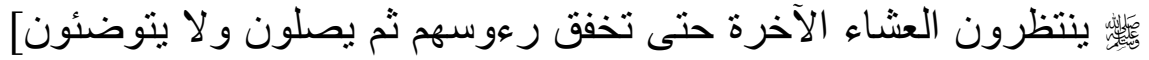

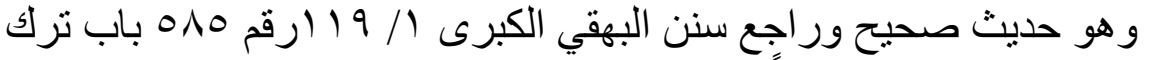

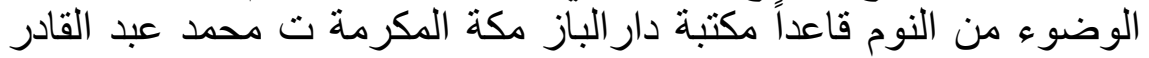




\section{دكتورة| بثينة رشاد محمود}

وكعلمه بأن أهل الكتاب يتعاملون بالريا ويشريون الخمر فلا يتعرض لهم • ويتصل بهذا ما استثل الحنفية به من إسقاط الزكاة في أشياء سكت النبي  الناس يتخذونها كما يتخذون الكروم والنخيل (1) وكان الأمر في إرساله المصدقين والسعاة في أقطار الأرض ظاهراً بيناً وكان إذا بعثهم كتب لهم الكتب فتقرأ بحضرته ويشهد عليها ، فلو كان يجب فيها شيء لأمر بأخذه ، ولو أمر لظهر كما ظهر غيره من الأشياء التي فيها الوجوب للأخذ فلما لم يكن كذلك دل على سقوط الزكاة عنها .

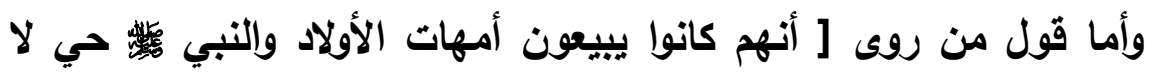
يرى بذلك بأساً ] (ץ) فإنها لم تجر بهذا المجرى في الدلالة على جواز بيعهن ؛ لأنه لا يعلم هل كان يبلغه هذا الفعل عنهم أو لم يظهر لله ذلك، وقد قام الاليل على فساد بيعهن من وجوه فلم يعترض به على تلك الدلالة.

وهكا ذكر الأستاذ أبو إسحاق الإسفراييني في كتابه من صور كون الثيء من الأمور العامة ولا يتعرض فيه بالأخذ والإيجاب، فيعلم أنه غير واجب ، كما قال الثافعي ومالك في الخضروات كانت على عهر الرسول -

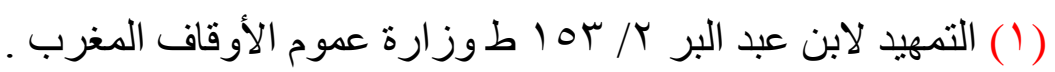

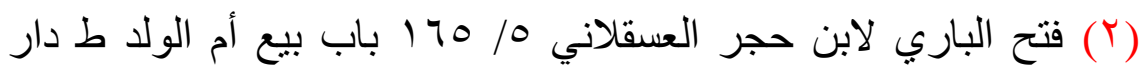

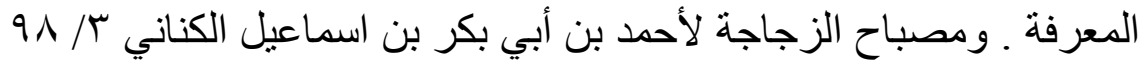

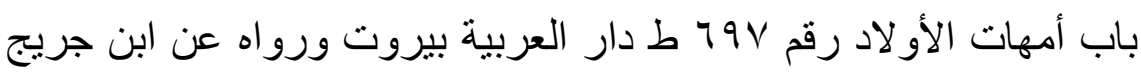
قال أخبرني أبو الزبير أنه سمع جابر بن عبد الله يقول [ كنا نبيع سرارينا

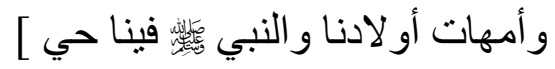


تركه يؤدي إلى ترك الفرض ، فأما المبايعات والإجارة التي لم ترد فيها

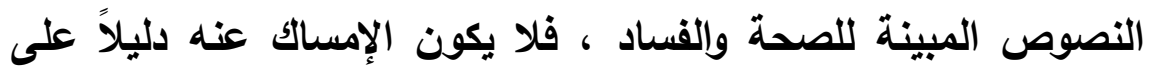

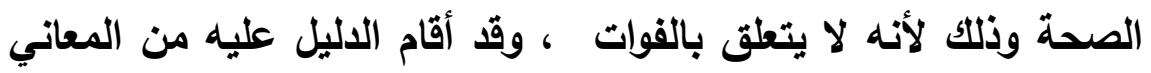
المودعة في النصوص ، ولا يكفي إقامة الالالة في مثل الخضروات ، بل ولا لإنه

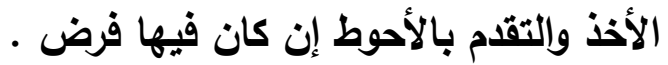
الصورة السادة : الاسل

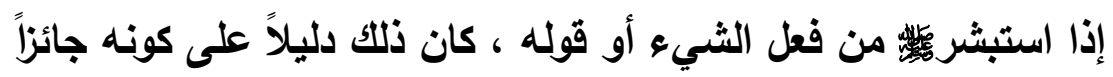
حناً ؛ لأنه 

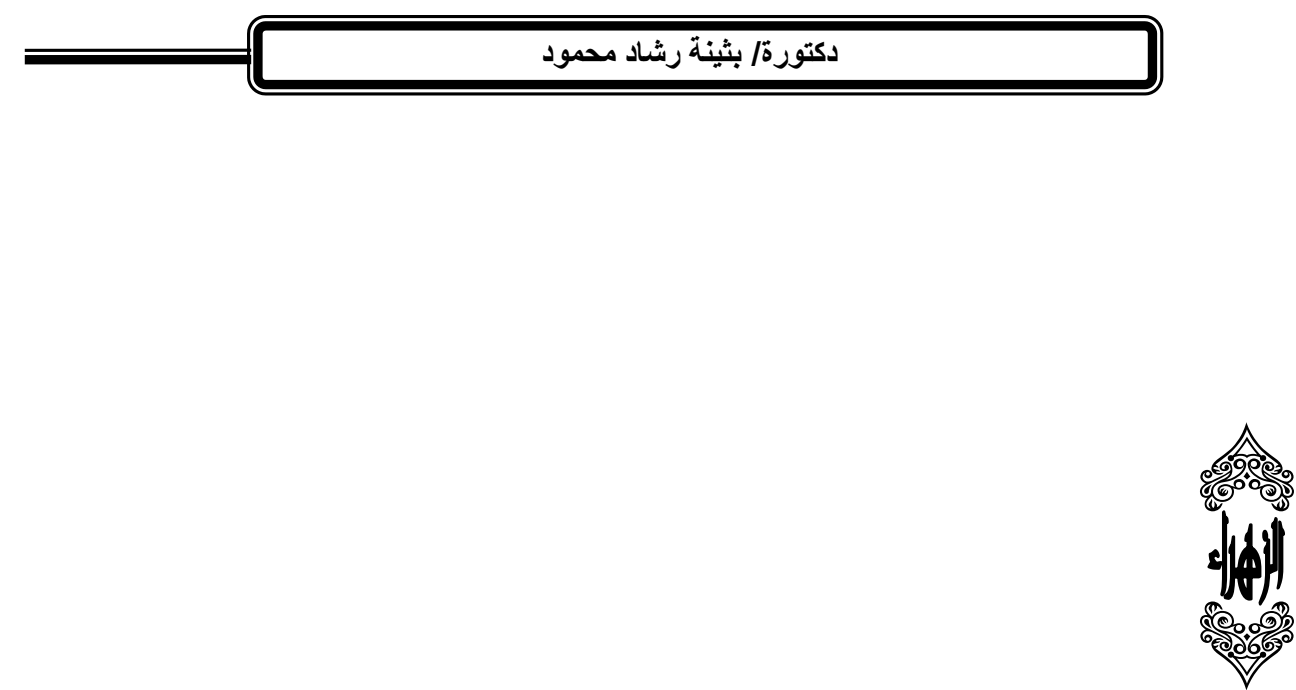


\section{السنة التقريرية كمصدر من مصادر التثريع}

\section{الإبمث الخامون \\ أحكام سكوته}

قال ابن السمعاني في القواطع : (1) إن مجرد السكوت لا يدل عندنا على سقوط ما عدا المذكور، كما يدل عند من يذهب إلى أن الأصل في الأثياء الإباحة إنما هو بحسب الحال وقيام الاليل عليه وذلك على ضروب . أمسا سكوت النبي فإنهـ دليل الجواز لأن الله تعالى وصفه بأنـه يأمر بـالمعروف وينهى عن لن المنكر فإن رأ الثيء وسكت عن ولم يغيره دل أنـه غير منكر وكذلك هذا فيما كان يبلغه عنهم ويعلمه ظاهراً من حالهم أو بتقريز عنه من عاداتهم مما سبيله الاعتبار والاستبشار فلا يعرض لهم بنكير . وأما الشيء إذا كان له أصل في الوجوب والسكوت فإن السكوت قد يقع عنه في بعض الأحوال استغناء بما يقدم من البيان فيه وليس تكرر البيان

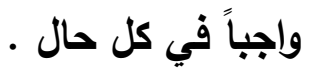
ذكر إلكيا أحكام السكوت () وهو أن يسكت - صل الله عليه وسلم -عمـا لم تشتمل عليه أدلـة الشرع وممـا ذكر لـه في القرآن ، والمستقتي ليس خبيراً بأدلة الثرع بصيراً بالأحكام ، قال فسكوت الرسول - صل الله عليه وسلم - في مثل ذلك حجة ؛ وإلا لزم تأخير البيان عن وقت الحاجة .

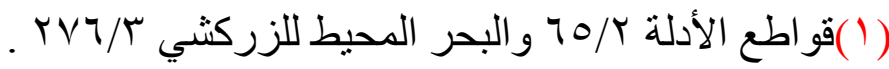

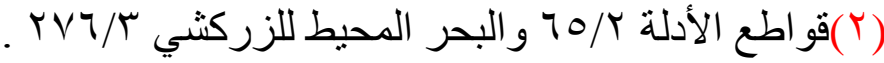




\section{دكتورة/ بثينة رشاد محمود}

مراتب الاستدلال بالسكوت (1)

إن مراتب الاستدلال بالسكوت تختلف :

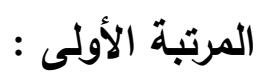

وهي أقوي ما يكون من مراتب السكوث وهي فيما إذا كان صساحب الحادثة

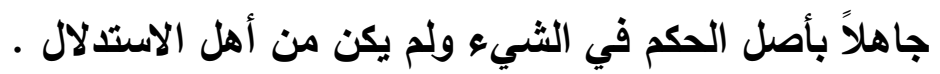

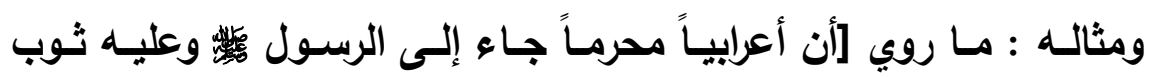

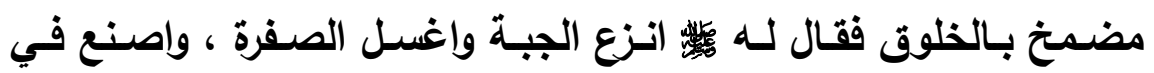

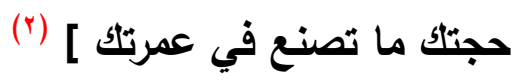
وسكت عن الكفارة فدل ذلك على أنها ساقطة عن الجاهل والناسي ولو كانت واجبة لذكرها إذ لم يكن يجوز إهمال ذكرها قولاً بنـاءً على معرفته بالحكم فيها مع العلم بحاله من الجهالة وذلك إن علم تحريم اللباس علم عام عند العرب في جاهليتها حتى أنهم كانوا لا يطوفون بالبيت إلا عراة

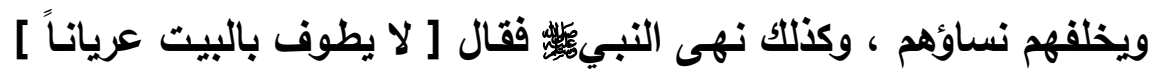

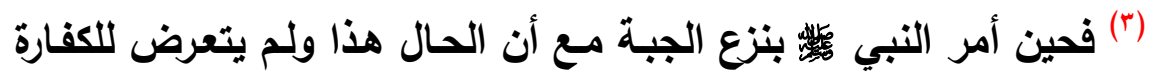
علمنا أنها غير واجبة . المرتبة الثانية : وهي ما إذا كان الصحابي يعرف حكم الله في المسـألة أو

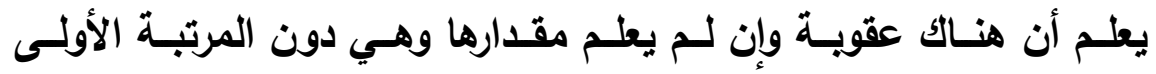

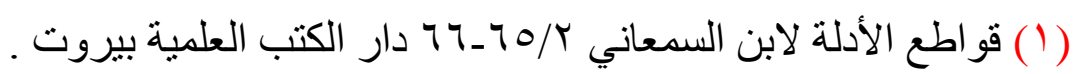

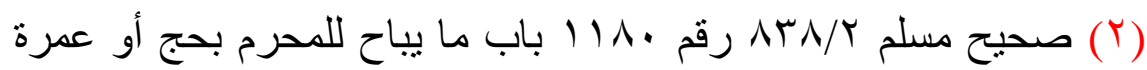

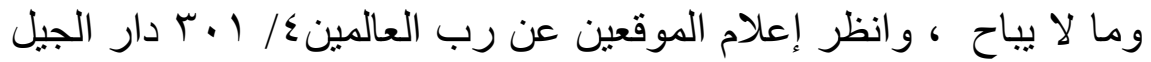
بيروت .

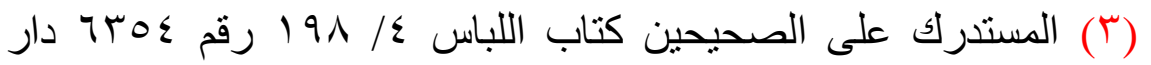
الكتب العلمية بيروت 


\section{السنة التقريرية كمصدر من مصادر التثريع}

ومثالها : خبر الأعرابي المجامع في في نهار رمضـان حين قال " هلكت وأهلكت" (1) وإنما جـاء يعرف حكم الله تعالى فيمـا فعله ويتوهم أن يلزمـهـ حد وضرب من ضروب العقويات ، فلما قيل له اعتق رقبة ، دل ظاهره أنه جواب عن هلاكه وإهلاكـه وهو إفطاره وإفطار زوجته وكانت امرأته إنمـا

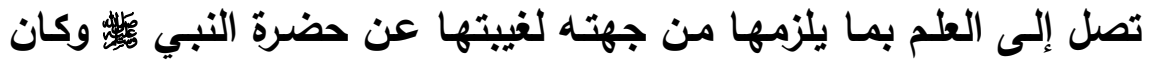
قوله " افعل كذا " محمولاً على أنـه يجزئ عنها وعنهـ. وإنمـا صـارت دلالـة هذا أضعف من دلالة الخبر الأول لأن ؛ السائل في هذا الخبر قد أنبأ عن

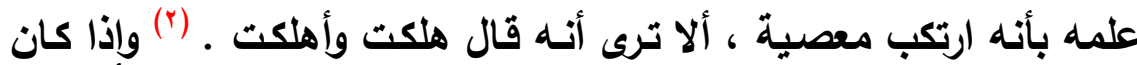

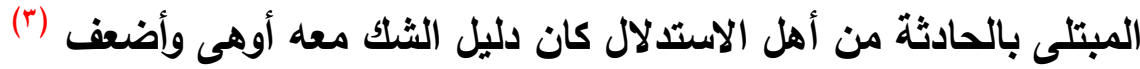
واعثبر الشـيرازي هـا المثـال مـن قبيـل مـا كـان فـي موضـع الحاجـة ، فالأعرابي سـأله عن الجماع في نهار رمضـان ، فأوجب عليه العتق ولم يوجب على المرأة، فدل سكوته على أنـه واجب عليه ؛ لأن تأخير البيان

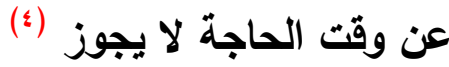

(1) فتح الباري باب إذا جامع في نهار رمضان ع / • V دار المعرفة وسنن

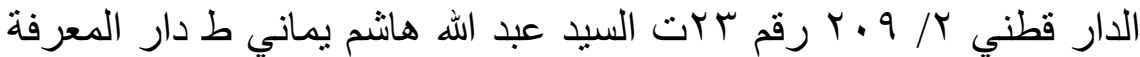

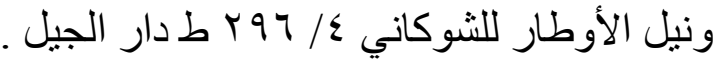

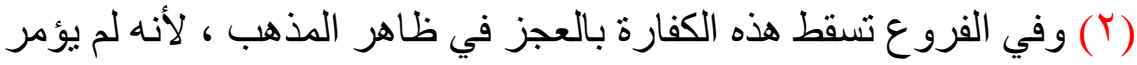

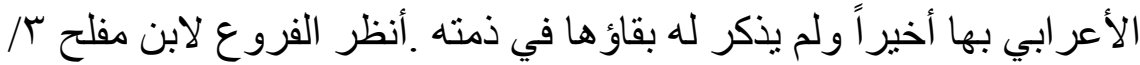

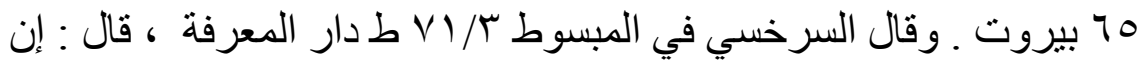
فيها زيادة [ تجزيك و لا تجزي أحداً بعدك ]فأن ثبتت هذه الرواية دل على فلى أنه كان مخصوصاً.

(T) قواطع الأدلة لابن السمعاني ؟ / 70 ط بيروت واللمع للثيرازي 79 بيروت . ( ) اللمع للثير ازي 99. 
وقال الزركشي في البحر : ومن هذا القبيل استدلال الثـافعي في مسألة الخارج من غير السبيلين بأنها ليس من الأحداث ؛ لأن الأحداث مقصـاة من الكتاب والسنة ولو كان من قبيل الأحداث لذكر في الكتاب والسنة ، فلو كان حدثاً كان من الأحداث المشهورة التي تعم بها البلوى ، واقتباس ولت

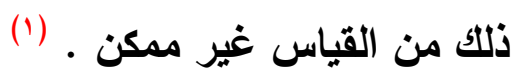

وقد اعترض ابن السمعاني على اعتبار هذا المثال من المسكوت عنـه فقال : وأما قول الشاقعي فيما يخرج من غير السبيلين : ذكر الله الأحداث في كتابه ولم يذكر هذا كومـا كان ريك نسيائ(؟) فإن قومـاً من أصحابنا تعلقوا به وقالوا إنما رده إلى أصل سقوط التكليف إلا بدليل ، وليس الأمسر

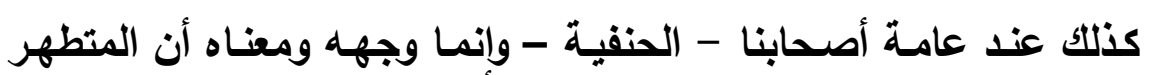
على طهارته ولا ينتقص وضوؤه إلا بحدث ومـا لم يقم دلالة على الحدث فأصل الطهر كاف فيه وقال ئس [ فلا ينصرف حتى يسمع صوتاً أو يجد ريحاً (ّ) ومن احتج من هذه الطائفة بقوله : ومـا سكت عنه فهو عفو فليعلم أنه ليس بعام في جميع أنواع السكت لكنه خاص في محل ؛ لأنـه

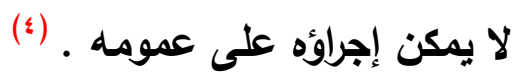

بينما نقل الزركثي عن إلكيا إن وقتي صلاة المغرب يعد من قبيل ما سكت عنه مع بيان غيرها من الصلوات حيث لم يبين لها وقتين مثل باقي

( (1) البحر المحيط للزركثي ب/ TVY ط محمد علي بيضون بيروت لبنان .

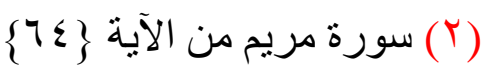

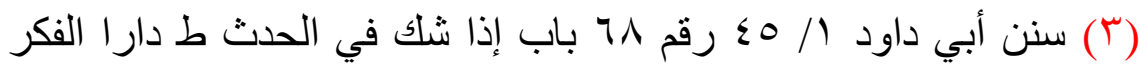

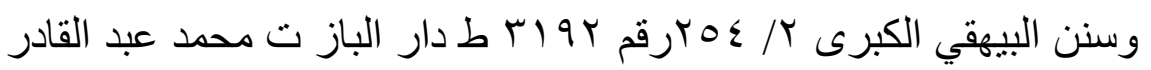
عطا.

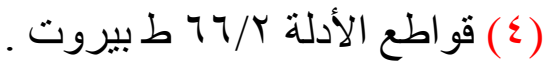




\section{السنة التقريرية كمصدر من مصادر التثريع}

الصلوات فلو كان لها وقتان لبينه جبريل وقال : ويشترط في هذا أن يكون المسكوت عنه لم تثمله أدلة الثرع فلو كان له ذكر فيها ، كم لو لو

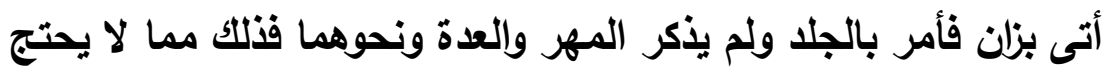

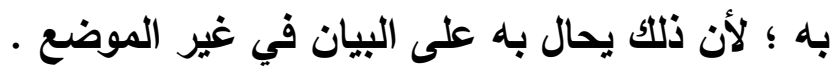

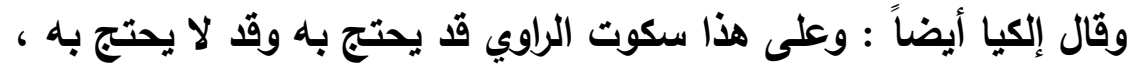
فإذا ساق الزاوي قضية ظهر منها أنه بعد استغراقها بالحكاية أنه لم يغادر

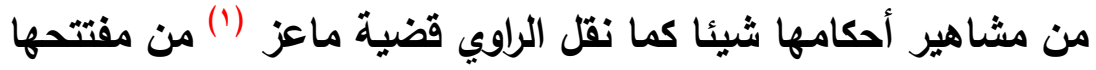

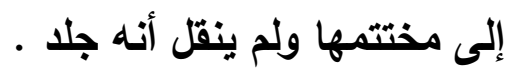

وردّ على هذا من ظن المعترض أن الجلد لا يتشوف إلى نقله عند نقل

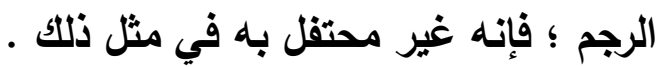

ويجاب بأن سياق القضية واستغراقه بتفاصيلها بالحكاية من غير تعرض فيرل للجلد دليل على نفي الجلد ، إذ لو جرى الجلد لنقله .

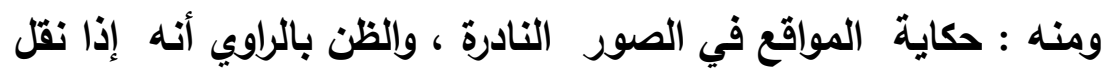
الحديث أن ينقل بصورتها إذا كانت الصورة نادرة ، وإذا سكت عنها

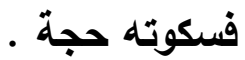

مثاله : ما روي أنه عليه الصلاة والسلام [ أقاد مسلماً بذمي وقال : أنا

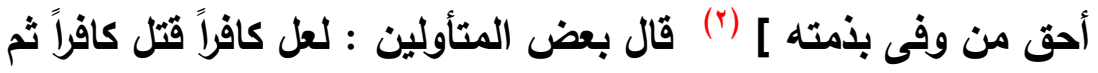

(1) شرح النووي على صحيح مسلم باب حد الزنا رقم • •179 وفيه وقد

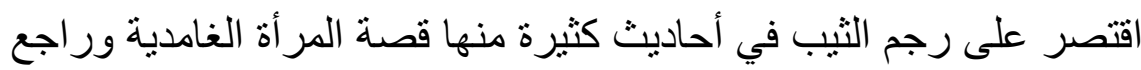

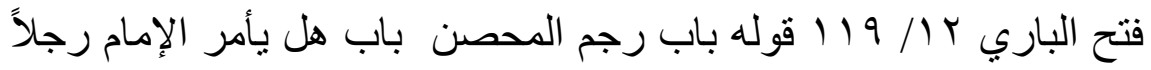

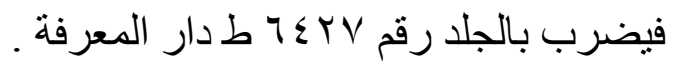

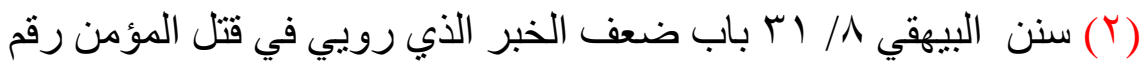
10791 مكتبة دار الباز مكة المكرمة ت محمد عبد القادر عطا والدار 
أسلم القاتل ، وفي ذلك نظر ؛ فإنه لو كان لنقل مثل ذلك على ندوره وتثوف الطباع إلى نقل الغرائب وهذا حسن . حكم ما استحسنه

بمعنى أنه هل استحسنه لكونه مندوياً إليه شرعاً ؟ أم لكونه لغرض عادي ب فيه احتمال

والأولى حلـه على الثـرعي ؛ لأنـه الأغلب من حاله عليه السـلام لكونهـ

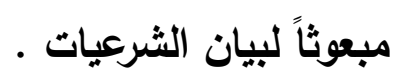
واعلم أن الاستبشسار أقوى في الالالـة على الجهواز مـن السكوت ولـنلك تمسك الشافعي في إثبات القيافة وإلحاق النسب بها باستبشار التبي بقول

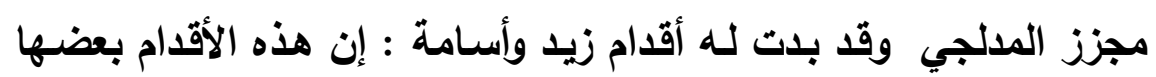

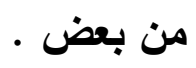
واستضعفه الغزالي في المنخول وقال : إنما سرّ بكلمة صدق صدرت ممن هو مقبول القول فيما بين الكفار على مناقضة قولهم لما قحوا في نسبة أسامة إلى زيل ، إذ كان رسول الله قد

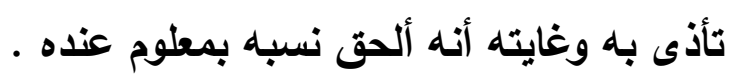
ورد عليه الطرطوسي وقال : لو احتج النبي عليه السـلام بمـا لا يعتقده لضحضت حجته عندهم ولقالوا : كيف تحتج علينا بالرمز والقيافة وأنت لا تقول به ؟ ونقل إلكيا أن هذا السؤال أورد على الشـافعي فقيل لـه : إنمـا ثبت نسبه بالرسول وقول مجزز لغو ؛ إذ القائف يقضى به في بيان نسب

قطني وفيه أن النبي وقال [ أنا أحق من أوفى بذمته ] كتاب الحدود ب/ هبا ما رقم المعرفة ط بيروت ت عبد الله اليماني ـ الئه 


\section{السنة الثقريرية كمصدر من مصادر الثثُريع}

ملتبس ، ولكن كان الاستبشار لانقطاع مظاهر الكفار عن نسب أسامة

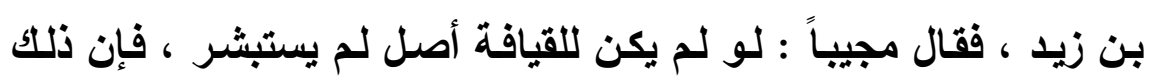

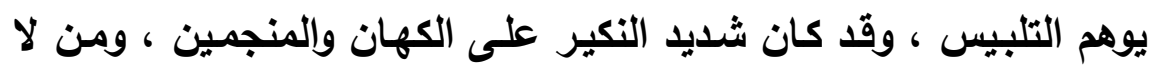

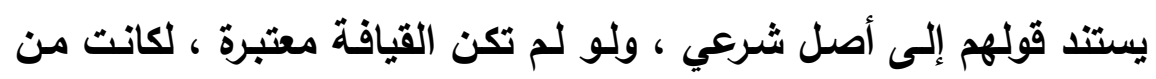

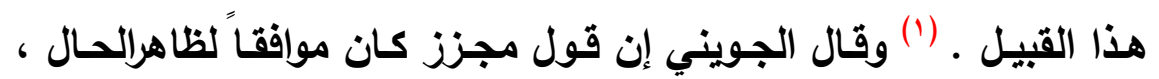

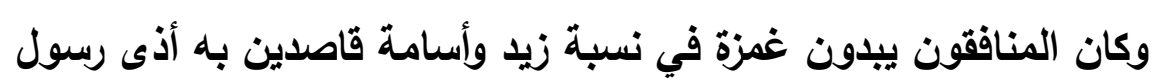

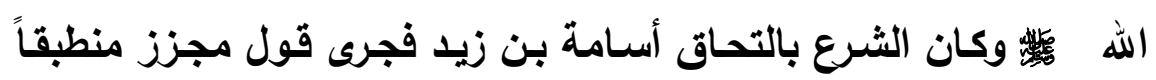

على وفق الثرع. (ץ) هذا وقد ذكر الغزالي (") إن مسألة تقرير رسول الله مسلماً على فعل

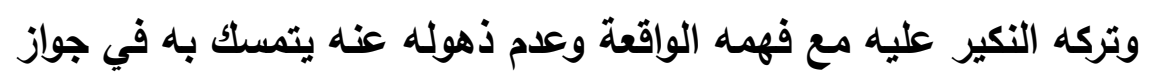
التقرير إذا كان الفعل بحيث لو قدر الإقدام عليه لكان كبيرة إذ كان يتحتم

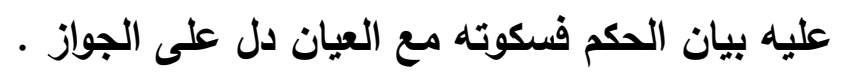

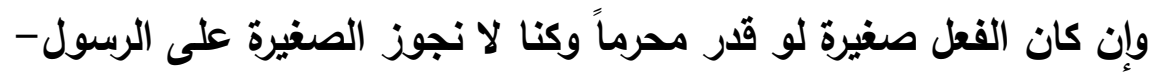

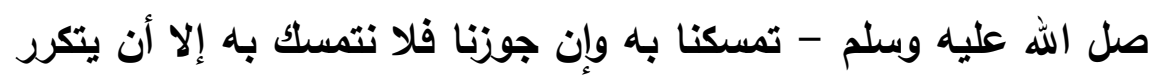

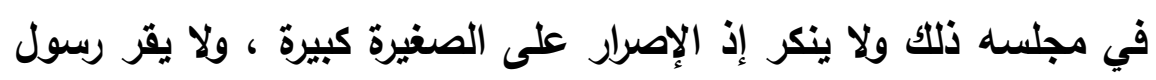

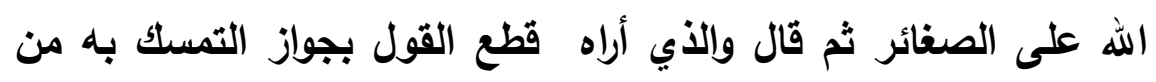

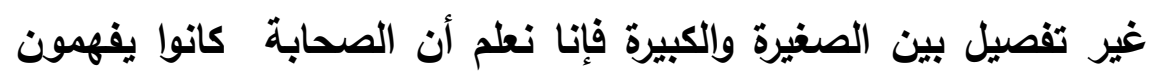

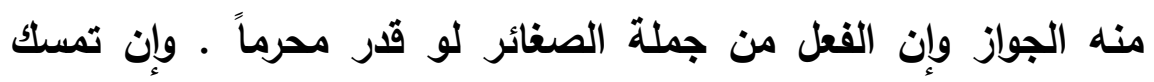

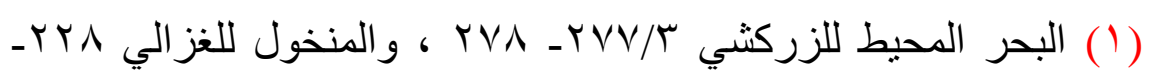

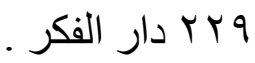

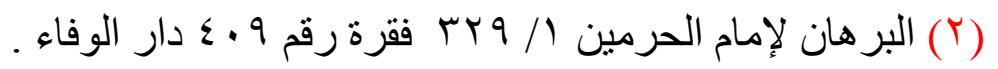

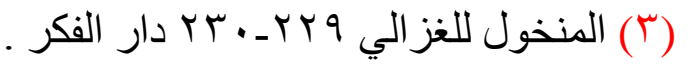




\section{دكتورة/ بثينة رشاد محمود}

متمسك به في إثبات عصمة النبي من غير تفصيل فله وجه . تمائ وأما تقريره الكافر فلا تمسك فيه ؛ لأنه كان يعرض عنهم .وفي تقريز المنافق خلاف لأنه كان ينحوا بهم نحو المسلمين .فإن قيل : إذا قرر مسلماً فيحتمل أنه كان ينتظر الوحي ؟ قلنا : لو كان كذلك لأمر بالتوقف كما نقل عنه في بعض الوقائع والله أعلم . حكم السكوت عن بعض ما يحتاج إلى بيان بعد الإجابة عن البعض إذا سئل رسول الله البعض وكان البعض المسكوث عنه مما يحتاج إلى بيان من الرسول

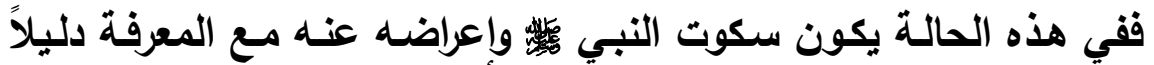

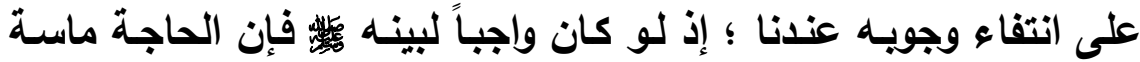
إلى البيان وتأخير البيان عن وقت الحاجة ممتنع اتفاقاً.

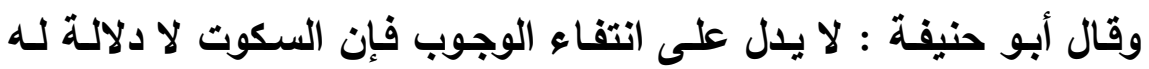
• على الأحكام

ويتفرع عن هذا الأصل أن : المطاوعة في نهار رمضـان لا يلزمها الكفارة

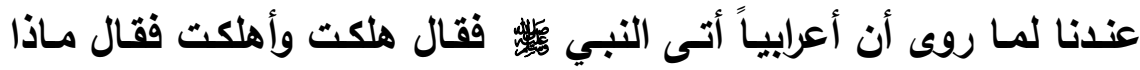
صنعت؟ فقال واقعت أهلي في نهار رمضـان فقال : عليه السـلام [ اعتق رقبة ] (') وسكت عن إيجابها على امرأته الموطويءة مـع أن الأعرابي لا يحسن الاسـتدلال فـل على أنهـا لا تجب عليهـا .وعنده تجب عليهـا

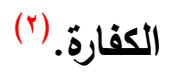

$$
\text { ( ) ( ) سبق تخريجه }
$$

(r) تخريج الفروع على الأصول للزنجاني ع با أمؤسسة الرسالة . 
بالبنة التقريرية كمصدر من مصادر التشريع

\section{المبحث السادس}

حكم التخصيص بالتقرير

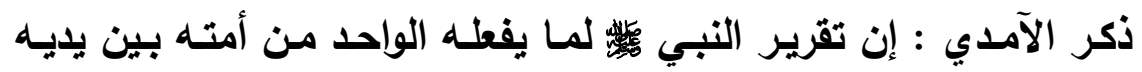

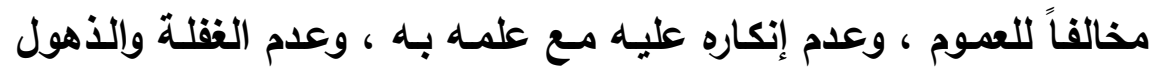

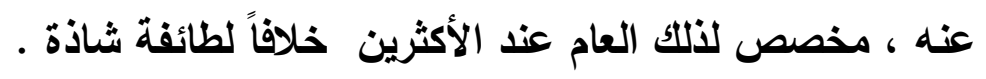

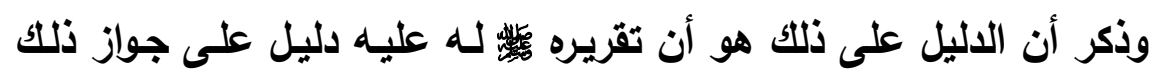

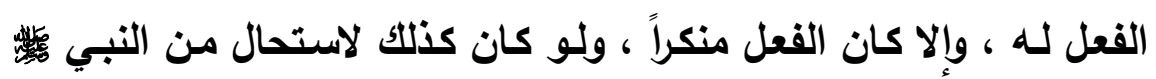

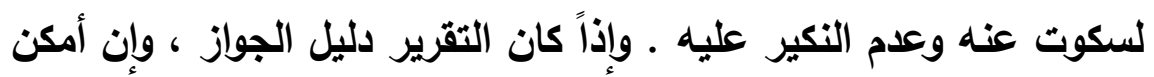

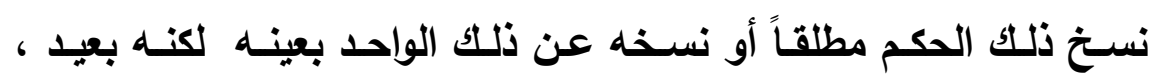
واحتمال تخصيصه من العموم أولى وأقرب .

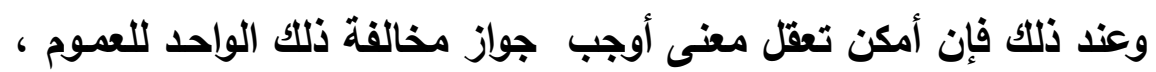

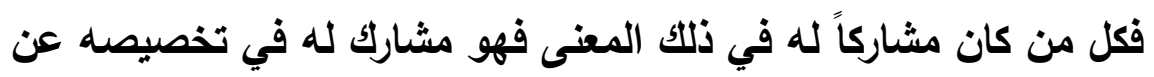

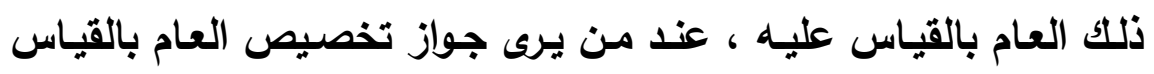

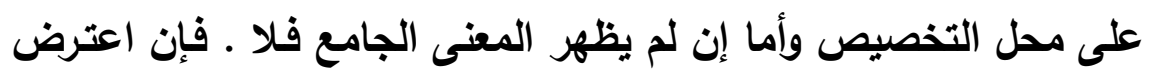

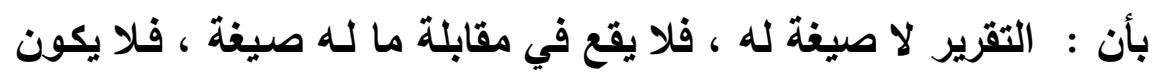

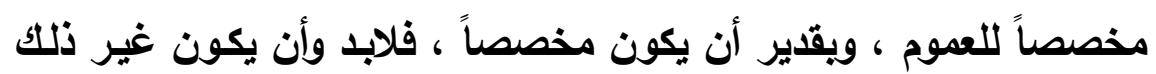

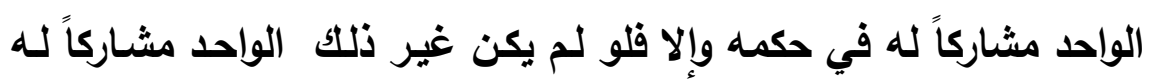
في حكمه لسرَ النبي

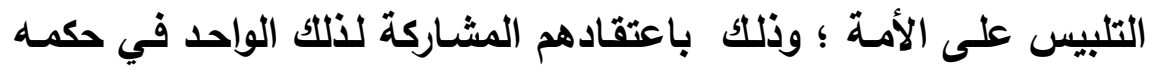


لقولـهـ - صـل الله عليـهـ وسـلم - [ حكمـي علـى الواحسـ حكمـي على

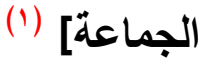

$$
\text { يجاب عن هذا : }
$$

بأنه وإن كان التقرير لا صيغة له ، إلا أنه حجة قاطعة في جواز الفعل

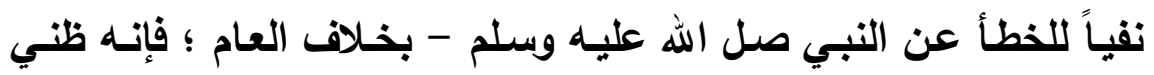

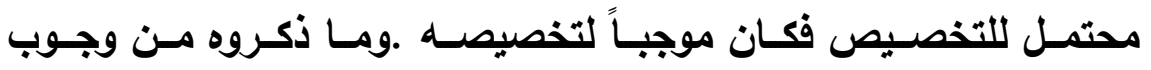

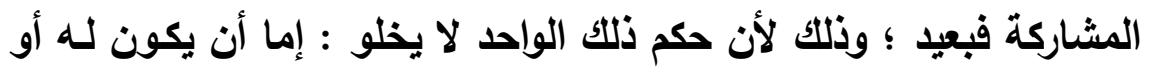
عليه فإن كان له فقوله [ حكمي على الواحد حكمي على الجماعة ] ـ إنما

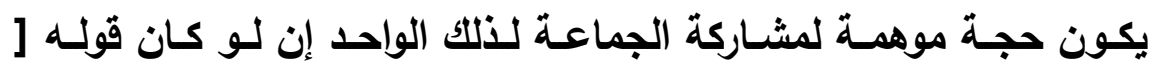

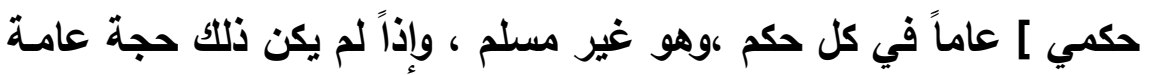

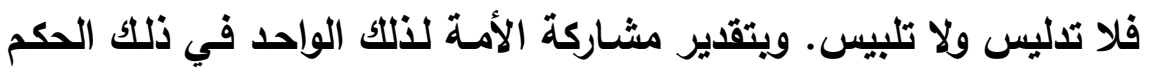

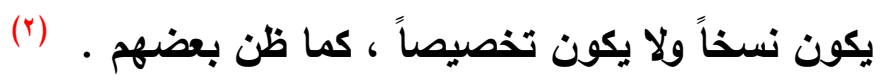

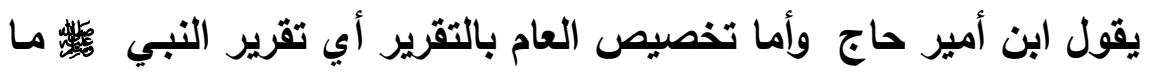

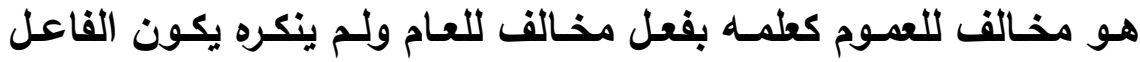

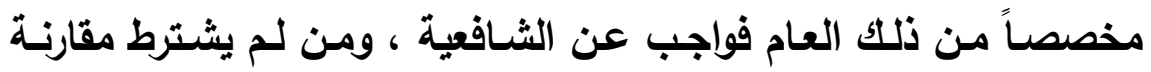
المخصص من الحنفية مطلقا ، أي سواء كان فعل الفاعل عقب ذكر العام في مجلس ذكره أو لا ؛ لأنه أي التخصيص أسها ، أسل من النسخ وأكثر وروداً

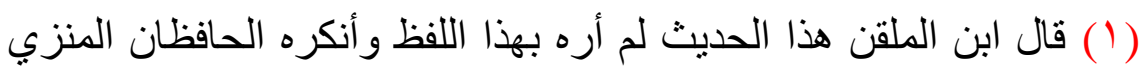

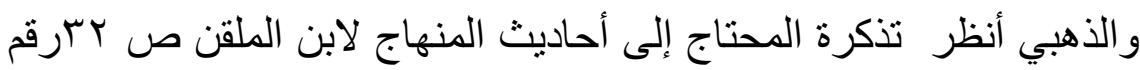

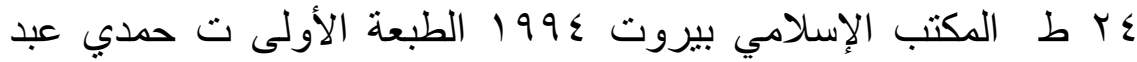

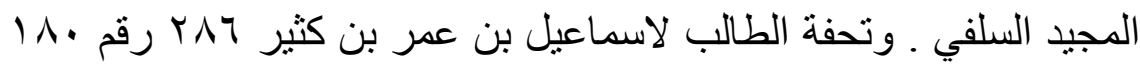

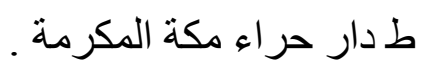

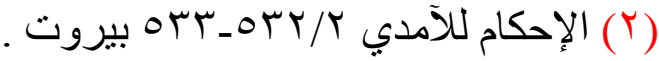




\section{السنة التقريرية كصدر من مصادر التثريع}

منه بشرط كون العلم بفعل الفاعل المخالف للعموم عقيب ذكر العام في مجلسه ، وإلا فإِن كان بعده في غير مجلسـه ، فنستخ لذلك العموم عند شارطي المقارنة من الحنفية للتخصيص وذلك لتراخيه .

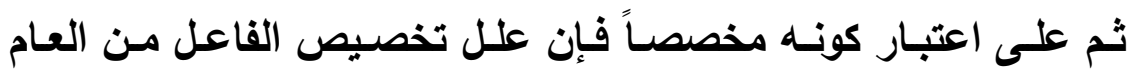

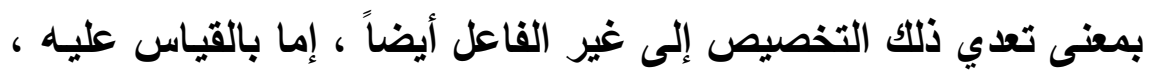

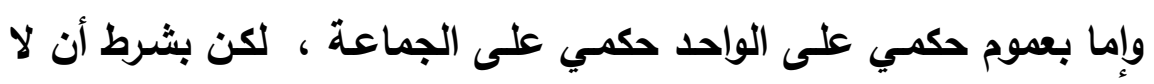

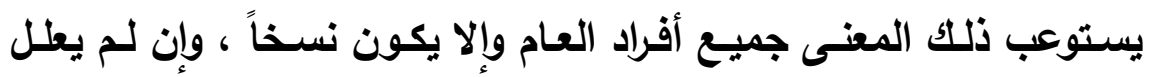

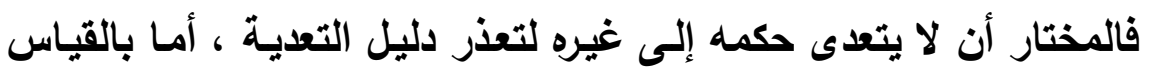

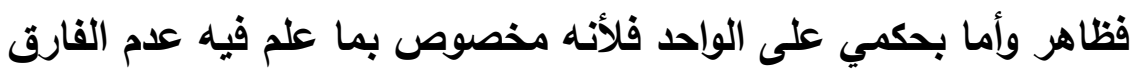

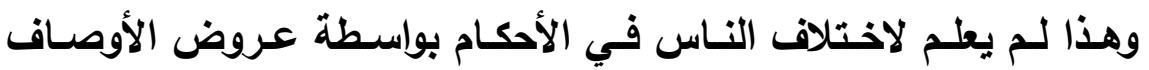
والأعذار (') وفي الإبهاج يقول ابن السبكي :

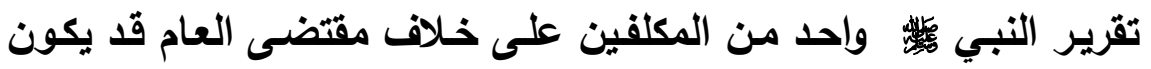
مخصصاً . مخربز أما في حق ذلك الثخص الذي أقر فلا شأن فيه ضرورة أنـه عليه السـلام لا يقر على باطل

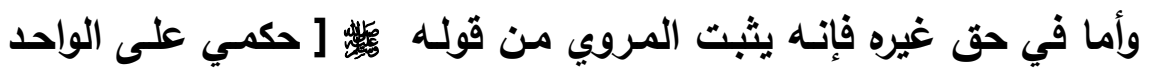

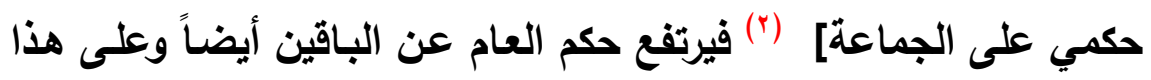
يكون نسخاً لا تخصيصاً إن خالف ذلكك الواحد جميع ما دل عليه العام .

( (1) التقرير و التحبير لابن أمبر حاج الحلبي /99 هب دار الفكر بيروت .

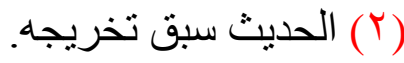


ويكون تخصيصـاً إن خـالف في فرد كمـا لـو قـال " لا تقتلـوا المسـلمين" وقدرنا أن شخصاً قتل مسلماً وأقره عليه السـلام على ذلك فيعلم أن ذلك فئك

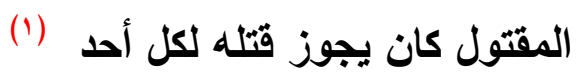

وهل يشترط في التخصيص أن يكون مقارناً ؟ جاء في القواتح :

إن التقرير هو السكوت عند روئية فاعل يفعل الفعل مع القدرة على المنع مخصص لاللك الفاعل عند الثافعية مطلقاً سواء كان مقارناً أو متأخراً وعند الحنفية إن كان العلم بالفعل في مجلس ذكر العام فمخص وإن لـ مان

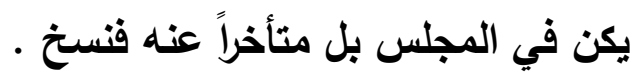
دليل الحنقية : واستدل العنفية بقولهم : إن السكوت عند العلم دليل الجواز عادة ؛ لأن عادتـه صل الله عليه وسـلم النهـي عن النكر فهو كالنص على الجواز ويناء على ذلك فهو مخصص عند الشافعية مطلقاً وعند الحنفية إن تأخر فناسخ وإن قارن فمخصص . ثم إن ظهر علة مشتركة بين الفاعل وغيره تعدى الحكم إلى غير الفاعل المشارك بالقياس أو ب [حكمي على الواحد حكمي على الجماعة ]. ثم إن تعدى الحكم بالقياس عند تأخر التقرير غير ظاهر فإنها يلزم حينئن تعليل الناستخ ونسـخ الحكم بالقياس ، إلا أن تكون العلـة مفهومـة لغة أو

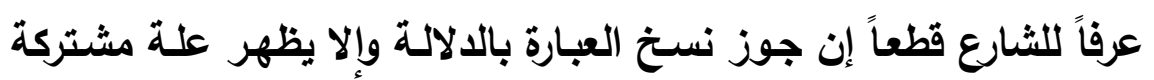
فالمختار عدم التعدية ؛ لأن التعدية من غير جامع غير معقول بينما .

( ) الإبهاج لابن السبكي r/ 1 ا دار الكتب العلمية بيروت الطبعة الأولى . 
بينما قال السبكي من الثـافعية : المختار عندنا التعميم مطلقاً ، وإن لـ

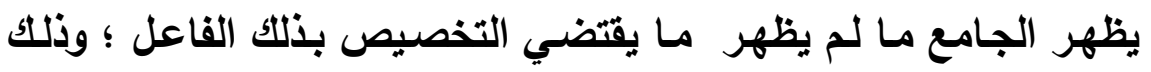
لقوله

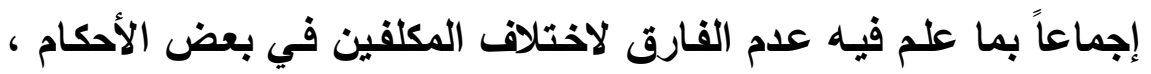

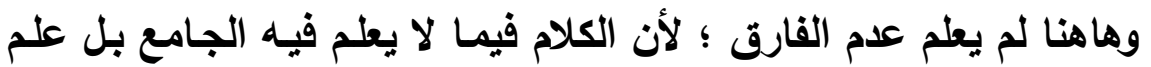

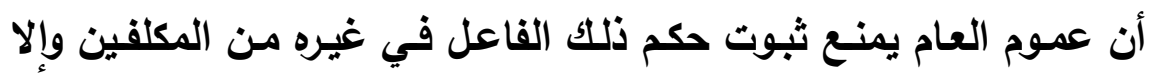

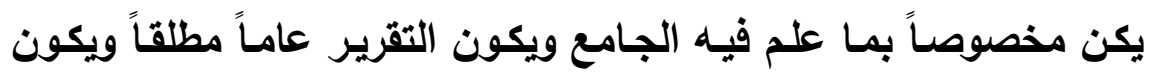

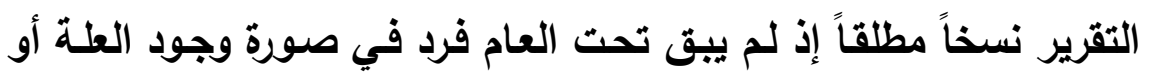

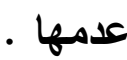
فإن قلت : لعله يكون في بعض الأفراد علة مانعة عن ثبوت حكم التقرير؟

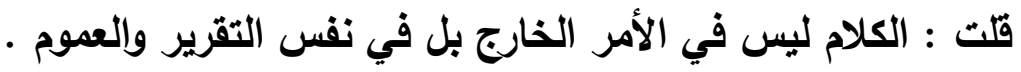

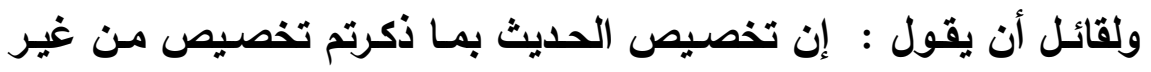

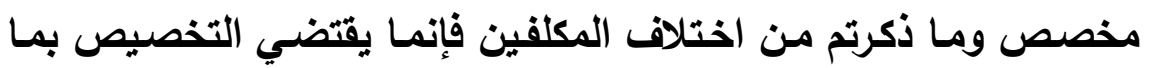

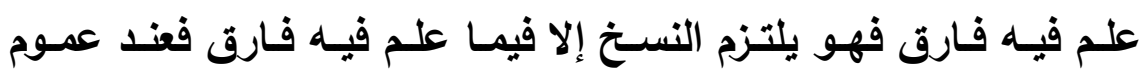

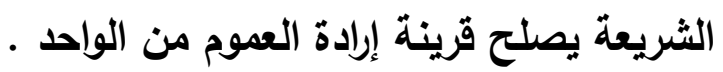

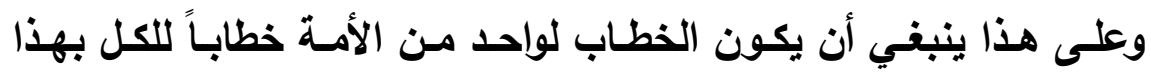

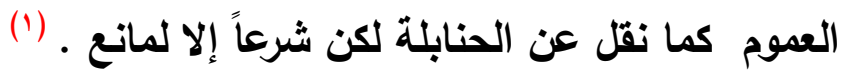
فرع

ويتفرع على تخصيص العام بالتقرير سؤال وهو : كيف يتم الاستدلال

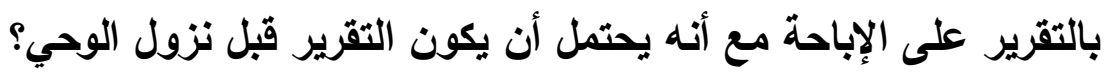

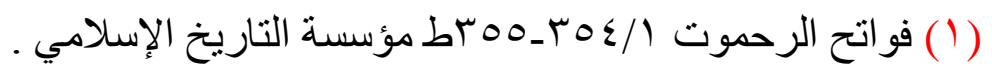


هذا السؤال طرحه ابن السبكي ثم قال : ينبغي أن يستلال به على عدم

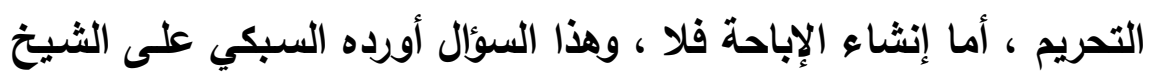
صدر الاين بن المرحل ولم يحصل عنه جواب وقال السبكي وقد ظهر لي بعد ذلك جوابه ، وهو أن التقرير إنما يكون على فعل قد وقع أو هو واقع. ثم قال ولنا قاعدة قد نقلوها وهي : إنه لا يجوز الإقدام على فعل حتى يعرف حكمه فكذلك الفعل الأي أقر عليه لو لم يكن مباحاً لكان حراماً عليه فلا عدم بحكمه فمن هنا دل التقرير على الإباحة بخلاف السكوت

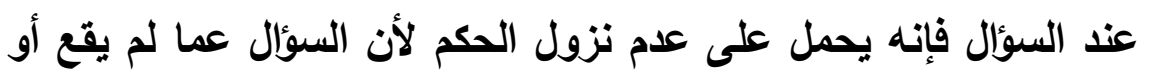
عما وقع والسائل ينتظر حكمه فيفهم من السكوت عدم الحكم فيقى واققاً، بخلاف المقيم على الفعل قد يعتقد إباحته فهذا الفرق بين المقامين.

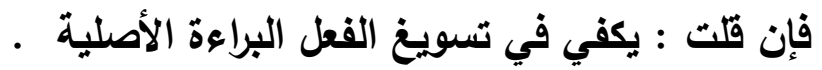
قلت : هذا كاف في الإباحة ؛ لأن إبقاء الشارع بحكم البراءة الأصلية حكم وهو دليل شرعي وإنما يقول بالتحريم إذا قدم بـلا سبب فهذا ينكر عليه ،

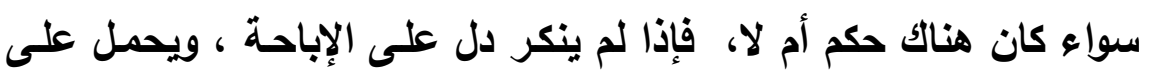
أن فاعله أقدم على علم . بخلاف السائل فإن ظاهر حاله أنه واقف على الاعتقاد منتظر الجواب فلا يحصل مفسدة (1) 


\section{السنة التقريرية كصدر من مصادر التثريع}

\section{المبحث السابع (الخهاف}

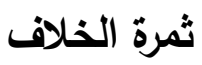

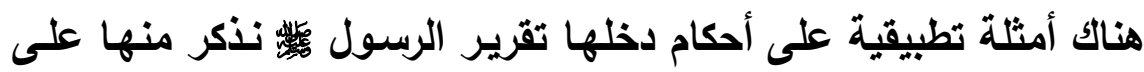

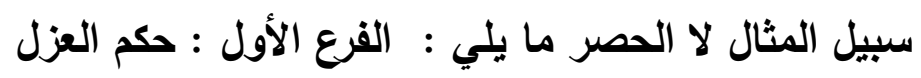

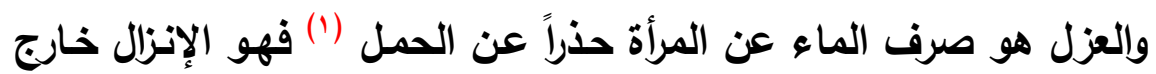

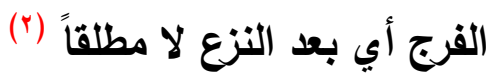

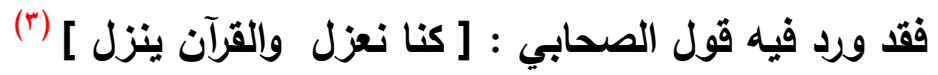

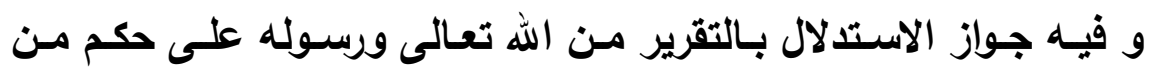

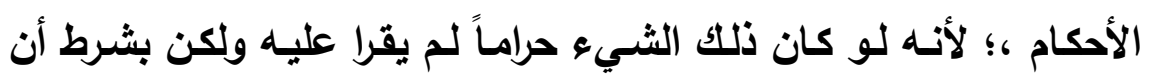

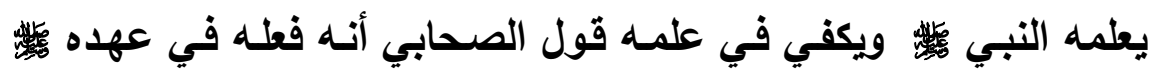

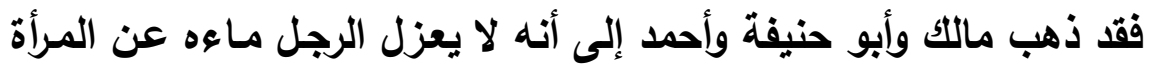

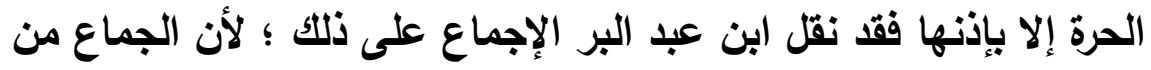

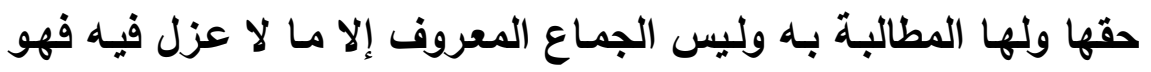

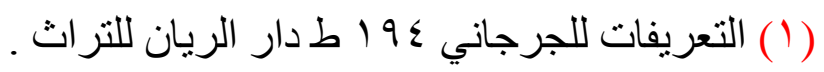

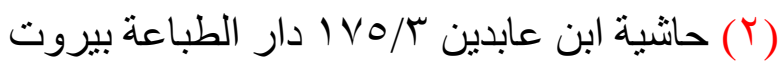

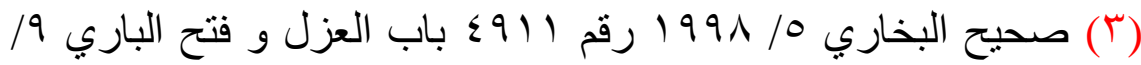

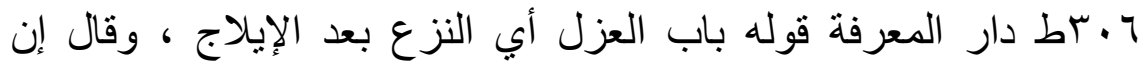

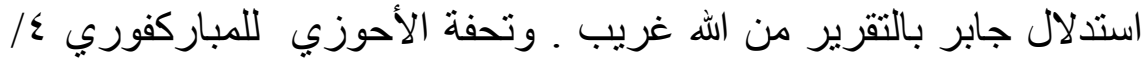

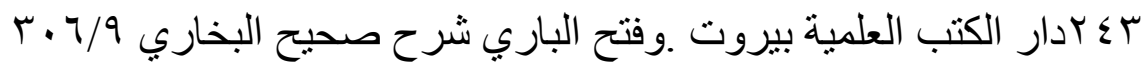

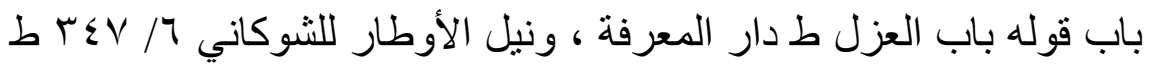

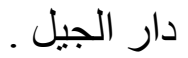


من تمام لذتها ولحقها في الولد وقث روى ابن ماجة عن عمر قال [ نهى

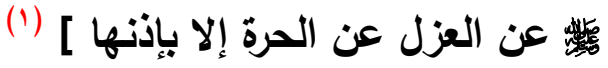

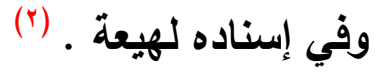

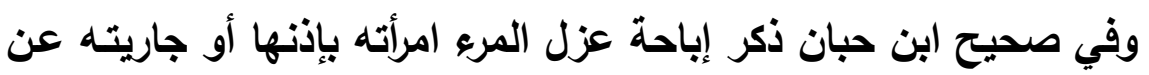

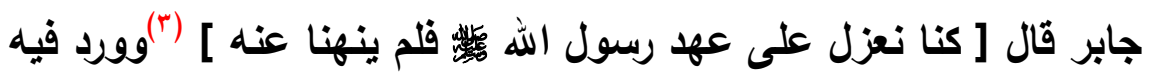

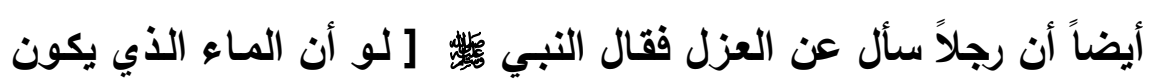

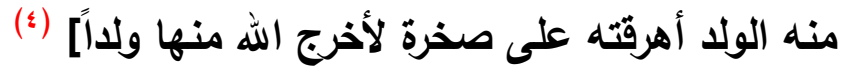

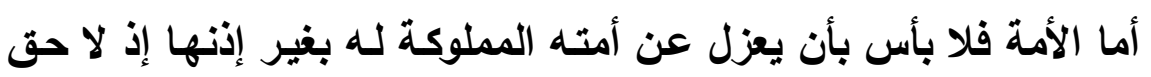

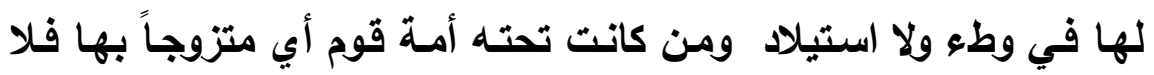
يعزل إلا بإنهم لحقهم في الولد وقال عياض ورأى بعض شيوخنا إننها

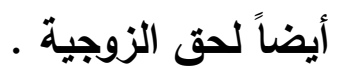
بينما ذهب الثـافعية إلى الكراهة مطلقاً على كل حال وفي كل امرأة وإن رضيت وذلك لأنه طريق إلى قطع النسل ولا يحرم في مملوكته ولا زوجته

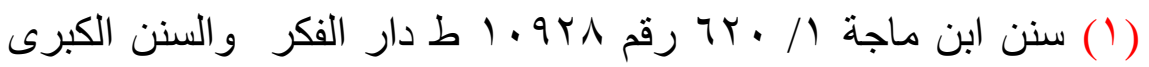

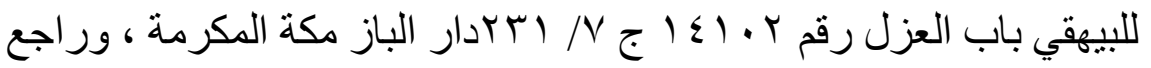

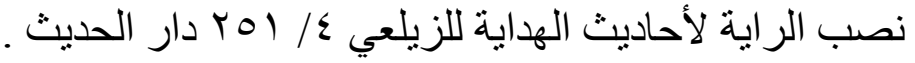

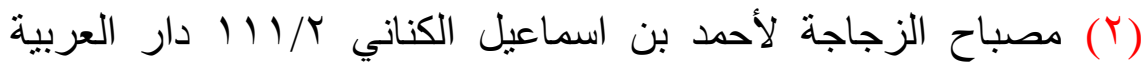

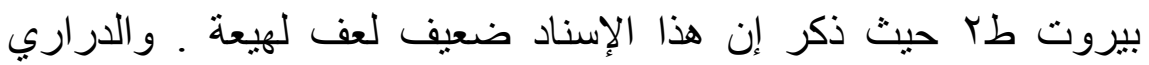

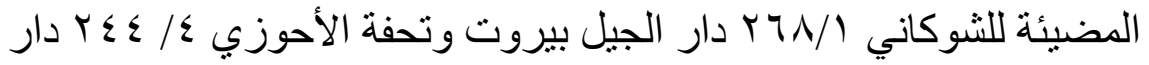

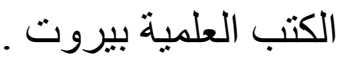

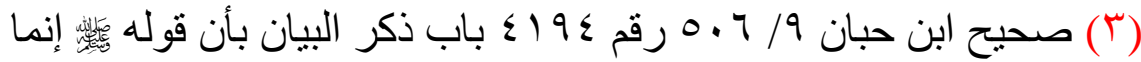

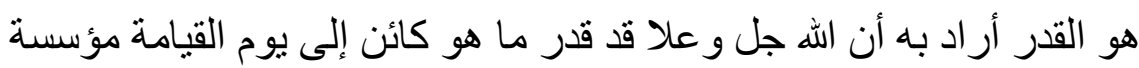

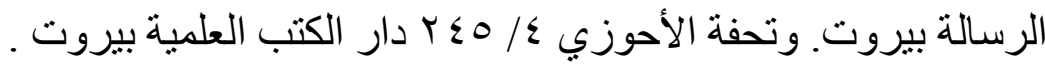

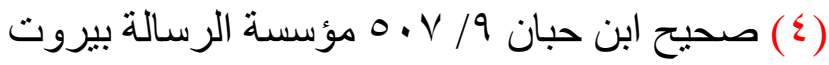




\section{السنة التقريرية كمصدر من مصادر التثريع}

الأمة رضيت أم لا ؛ لأن عليه ضراً في أمته بصيرورتها أم ولد رقيقاً ،

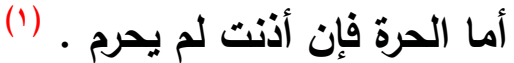

الفرع الثاني : حكم صلاة ركعتين بعد غروب الثمس فقد ورد عن النبي

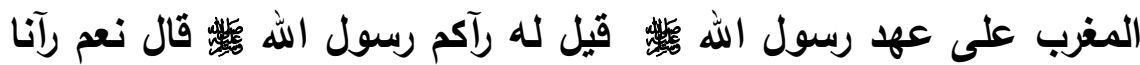

(ץ) ]لم يأمرنا ولم ينهانا حتى أن أنس رضي الله عنه كان يقول: [ لقد رأيت كبار أصحاب رسول

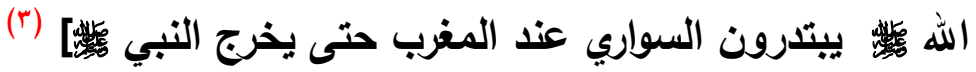

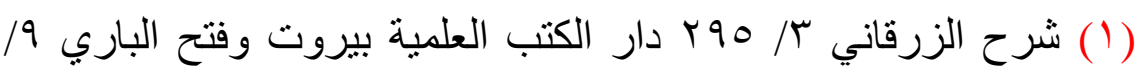

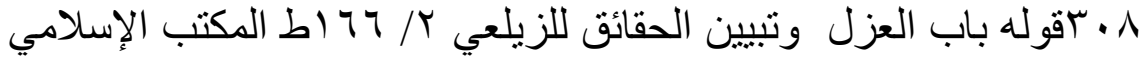

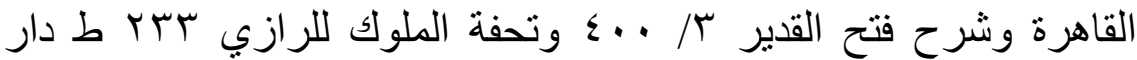

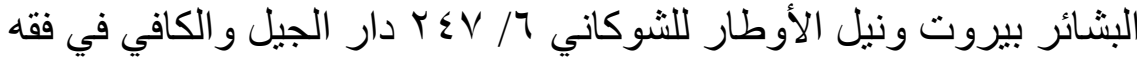

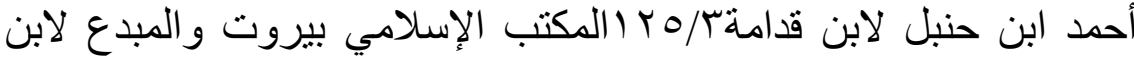

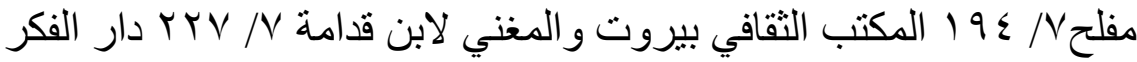

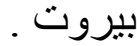

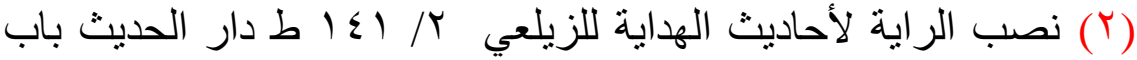

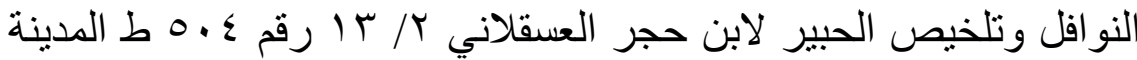
المنورةت السيد عبداله هاشم اليماني .

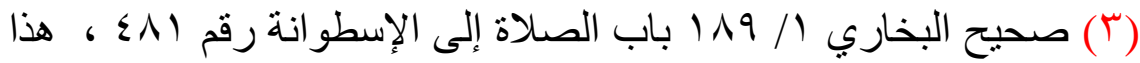

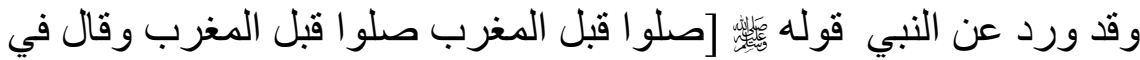

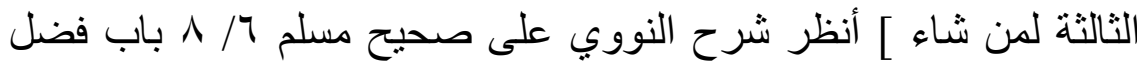

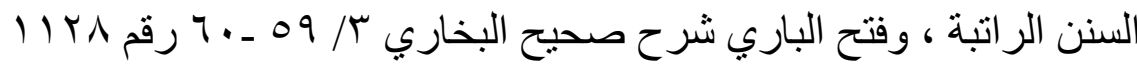




\section{دكتورة| بثينة رشاد محمود}

هذا وقد منع الحنفية من التفل بعد غروب الثمس قبل أن يصلي المغرب

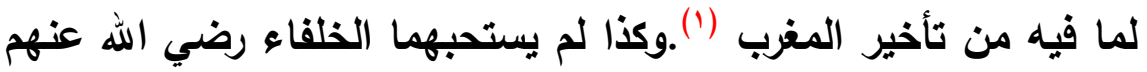
وآخرون من الصحابة ومالكك وأكثر الفقهاء واحتجوا بما ورد من أحاديث تحث على تعجيل صلاة المغرب منها قوله - صل الله عليه وسلم - لا تزال أمتي بخير ما لم تؤخر المغرب ] (ץ) وقالوا إن فعلهما يؤدي إلى

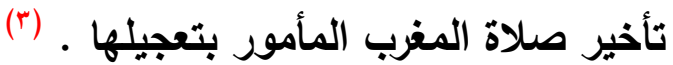
بينما استحبهما جماعة من الصحابة والتابعين و الشافعي وأحمد واسحاق والظاهرية واستدلوا بما ورد من تقريز النبي عدم كراهة الصلاة لا سيما والفاعل لذلك عدد كثير من الصحابة كذا في نيل الأوطار .وقد سأل عنهما الحسن البصري فقال :" حسنتين جميلتين

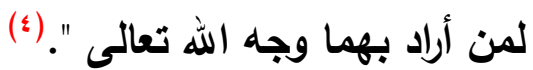

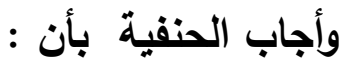
ذلك كان في ابتداء الحال ليعرف أن وقت الكراهة قد خرج بالغروب ، ولهذا لم يفعله أحد بعدهم قاله أبو بكر ابن العربي . وقال النخعي هي بدعة وإذا اتفق الناس على ترك العمل بالحديث المرفوع لا يجوز العمل به لأنه دليل ضعفه فما ظنك بفعل بعض الصحابة (•)

$$
\text { ( ( ) أنظر تبيين الحقائق للزيلعي NV/ دار الكتاب الإسلامي . }
$$

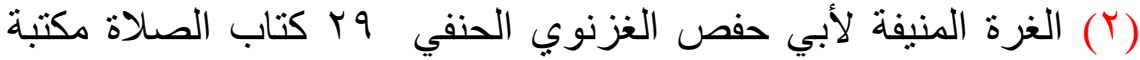

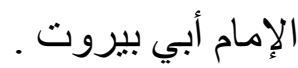

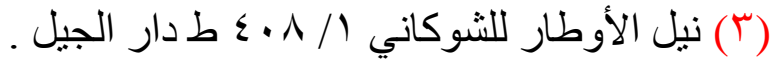

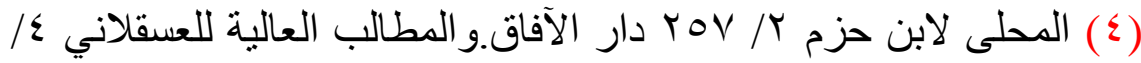

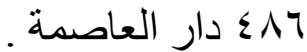
(0) تبيين الحقائق للزيلعي / NV دار الكتاب الإسلامي القاهرة . 


\section{السنة التقريرية كمصدر من مصادر التثريع}

والحق أن الأحاديث الواردة بشرعية الركعتين قبل المغرب مخصصة لعموم أدلة استحباب التعجيل ('). وقال النووي (†) وأما قولههم إن أداء الركعتين يؤدي إلى تأخير المغرب ، فهذا لا يلتفت إليه لأن زمن أداء الركعتين يسير لا تتأخر به الصلاة عن أول وقتها .

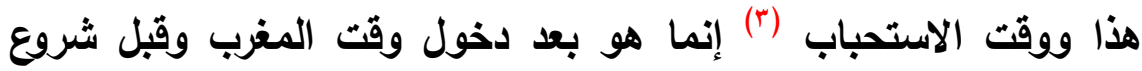
المؤذن في إقامة الصلاة وأما إذا شرع المؤذن في الإقامة فيكره أن يشرع

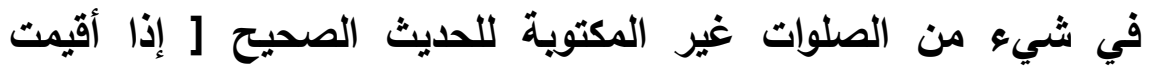

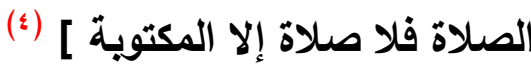
الفرع الثالث : حكم إخراج زكاة الخيل فقد ثبت تقريره أس لعدم إخراج الزكاة من الخيل وهذا يخصص عموم

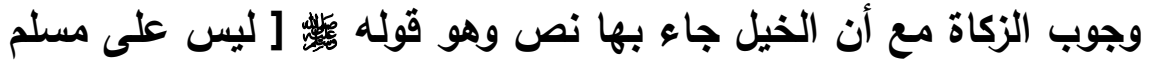
في فرسه ولا عبده صدقة ] (0) قال ابن حزم : الجمهور على أنه لا زكاة النهاة

(1) (1) أنظر نيل الأوطار للثوكاني 1/1 •ـ دار الجيل .

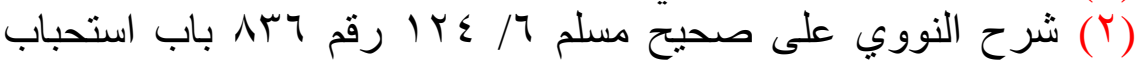

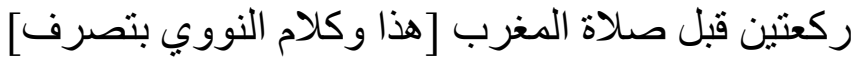

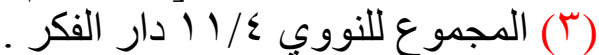

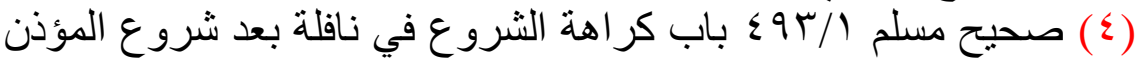

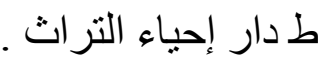

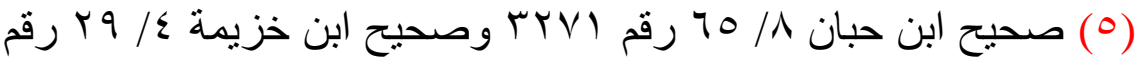

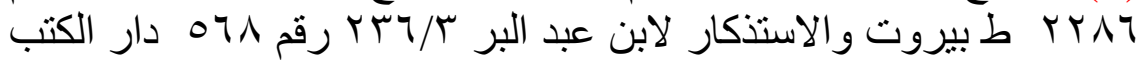

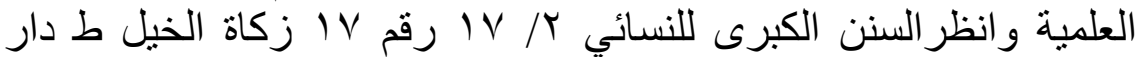

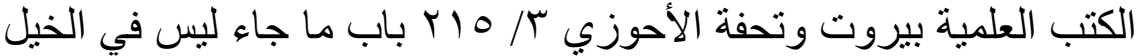

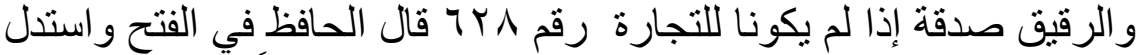

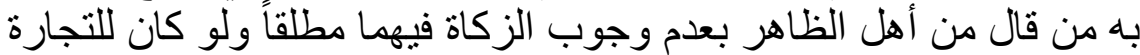

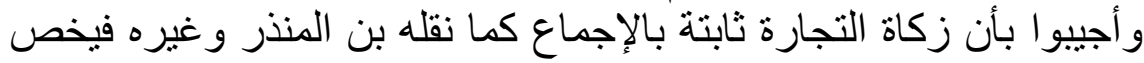

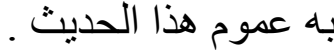




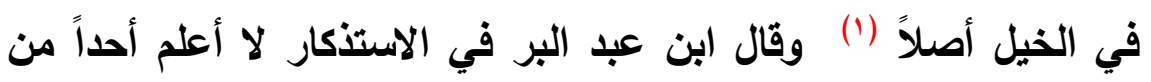

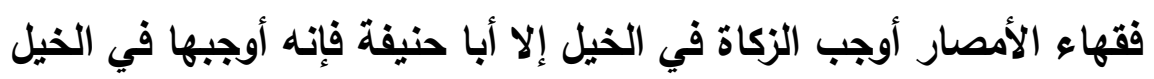

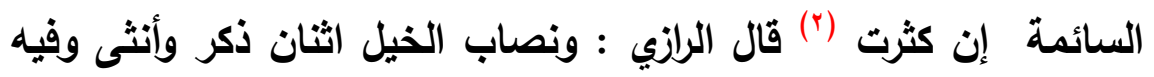

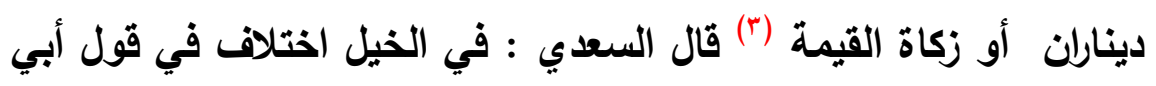
حنيفة وسفيان فيها الزكاة في كل فرس دينار أو عشرة دراهم أو يقومها

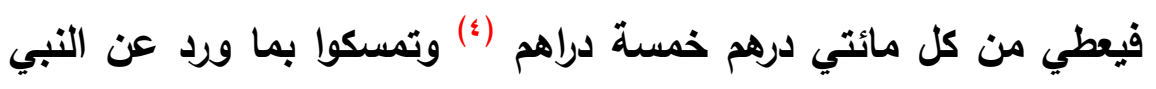

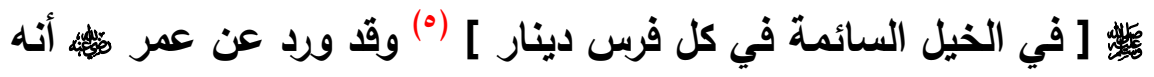

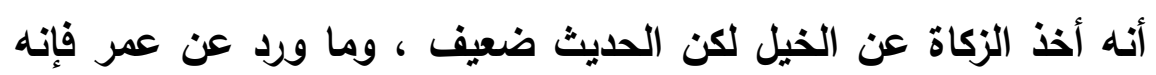

إنما أخذها على أنها صدقة تطوع منهم لا واجبة (").

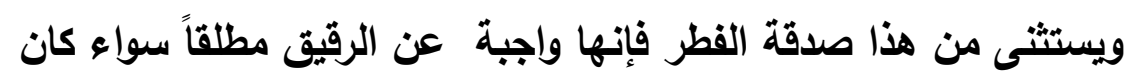

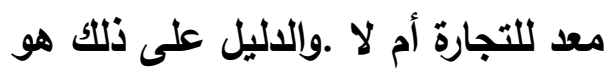

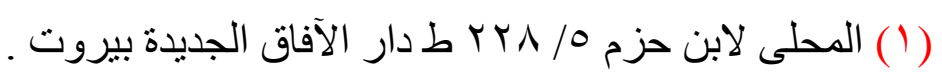

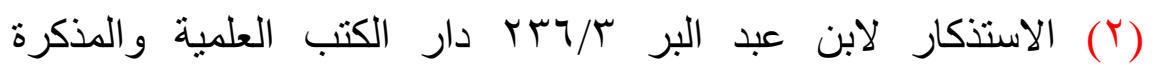

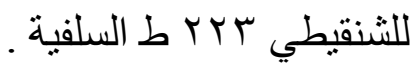

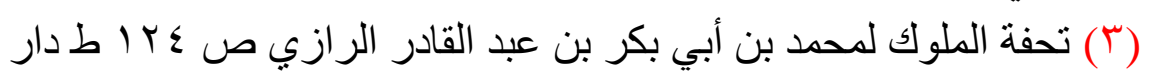

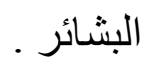

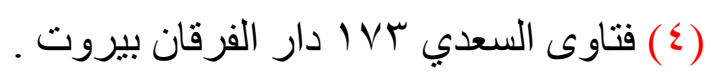

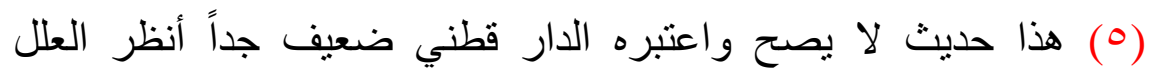

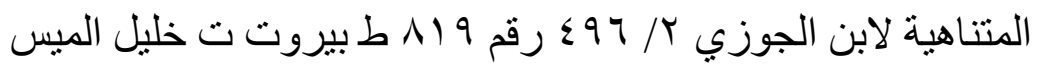

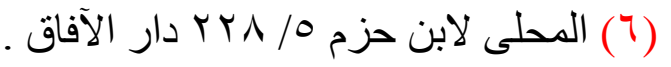


ما ورد عن ابن عباس من من أن رسول الله ينادي أن صدقة الفطر حق واجب على كل مسلم صغير أو كبير ذكر أو

أنثى حر أو مملوك حاضر أو باد صاع من شعير أو تمر ] [(')

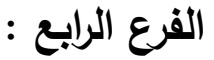

وجوب الكفارة على المرأة التي واقعها زوجها في نهار رمضان لقد أمر النبي وسكت

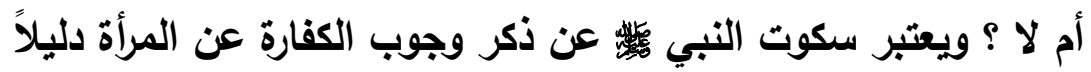
على عدم الوجوب ؟ فأقول ويالله التوفيق: حكم وجوب الكفارة على المرأة المطاوعة في نهار رمضان فهل تجب الكفارة عليها كما وجبت على الزوج أم إن الكفارة تجب لمبان على الزوج فقط ؟ ويعد سكوت النبي - صل الله عليه وسلم - عن بيان حكم امرأة الأعرابي يعد هذا تقريراً لعدم وجوب الكفارة عليها؟ - ما؟ اختلف الفقهاء : فذهب أبو حنيفة وأصحابه ومالكاً وأصحابه أوجبوا عليها الكفارة

وقال الثافعي وداود في لا كفارة عليها (ץ)

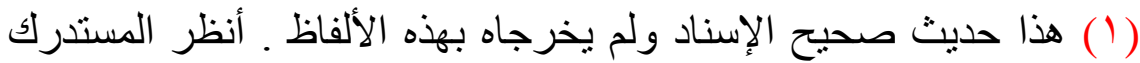

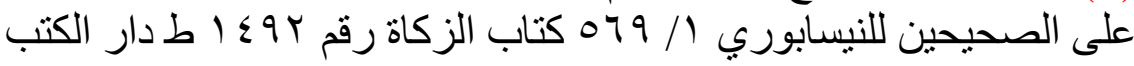

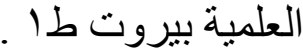

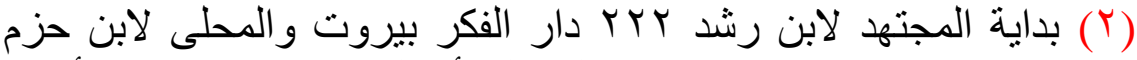

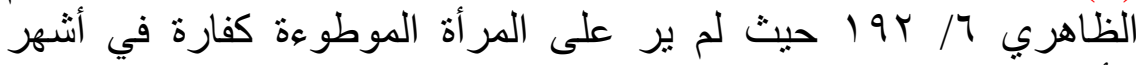

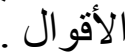




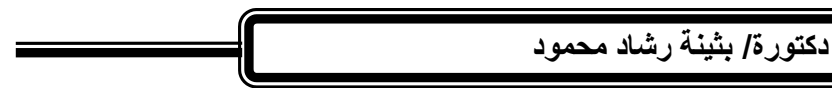

ولأحمد روايتان (') : (لأن

الأولى : إنها تجب لأن المرأة إحدى المتواطئين فيلزمها الكفارة كالرجل .

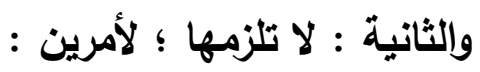

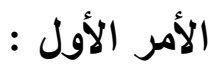

لأن النبي الأس لم يأمر امرأة المواقع بكفارة .

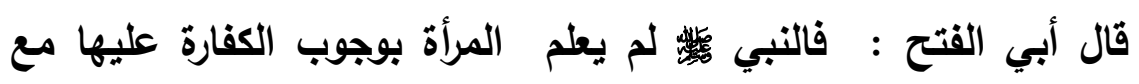

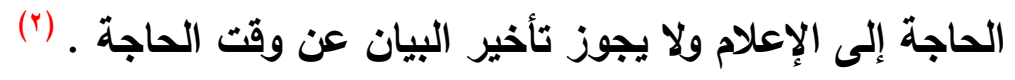

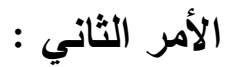

لأنه حق مال يتعلق بالوطء من بين جنسه فاختص بالرجل كالمهر (")

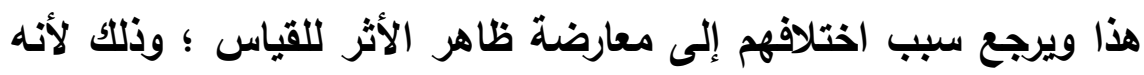

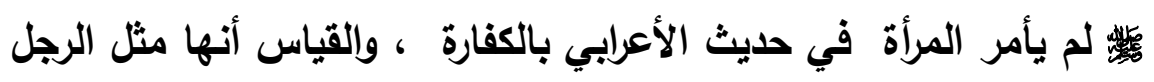

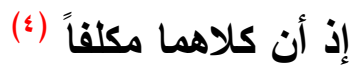
فإن كانت ناسية أو مكرهة فلا كفارة عليها رواية واحدة لأنها تعذر بالعذر

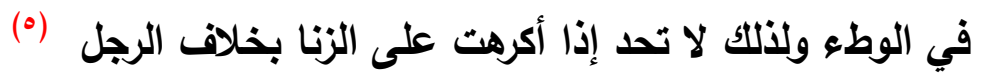
الفرع الخامس : الطلاق ثلاثاً بعد اللعان

(1) المبدع لابن مفلح الحنبلي أبو اسحاق ب/ ب س ط المكتب الإسلامي حيث

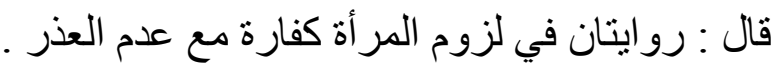

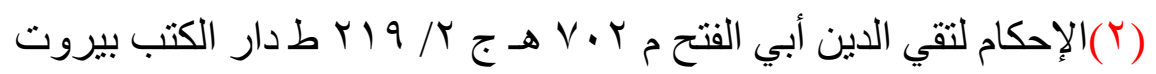

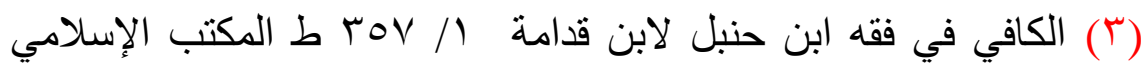

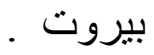

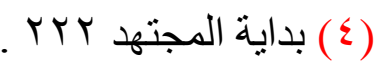

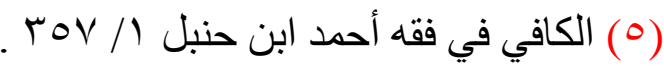




\section{السنة التقريرية كمصدر من مصادر التشريع}

فقد ورد في حديث اللعان أن الزوج وهو العجلاني طلقها ثلاثًاً بحضرته ولم ينكر عليه (') وهنا يرد مسألتان: الأولى : حكم الطلاق بعد اللعان والثانية : حكم الطلاق الثلاث بلفظ واحد. فأما الأولي وهي حكم الطلاق بعد اللعان وهل وقوع اللعان من الزوجين أو أحدهما يوجب الفرقة من غير حاجة إلى النطق بالطلاق أو قضاء القاضي أم أنه لا با من الطلاق اختلف العلماء في الفرقة باللعان فقال الحنفية لا تقع الفرقة بعد فراغهما من اللعان حتى يفرق الحاكم بينهما ، ويه قال الثوري وأحمد. وقال مالك والليث وزفر إذا فرغا من اللعان وقعت الفرقة وإن لم يفرق

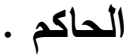

وقال الثوري والأوزاعي لا تقع الفرقة بلعان الزوج وحده . وقال عثمان البتي لا أرى ملاعنة الزوج امرأته ينقص شيئاً يعني من

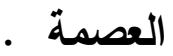

وقال الشافعي إذا أكمل الزوج الشهادة والإلتعان فقد زال فراش امرأته ولا تحل له أبداً التعنت أو لم تلتعن قال أبو جعفر قول البتي لم نجده عن أحد

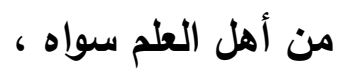
ولعل السبب في هذا الخلاف هو ما ورد من قصة العجلاني من أنه طلقها

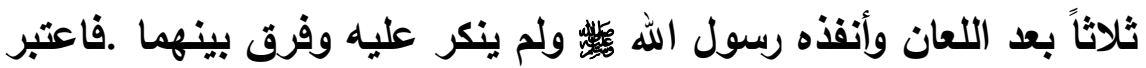

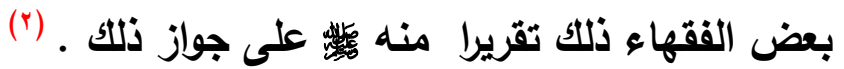

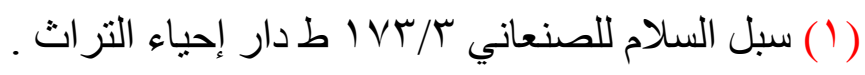

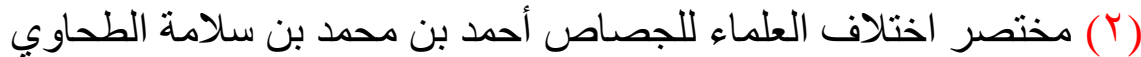

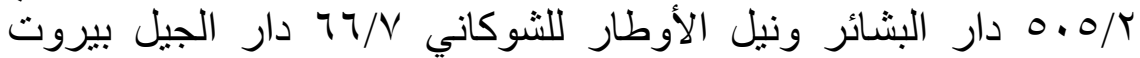

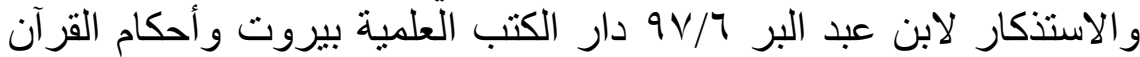

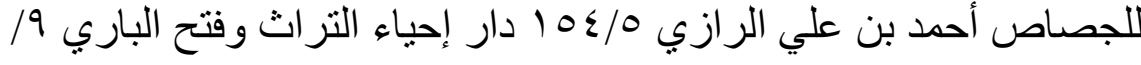




\section{دكتورة/ بثينة رشاد محمود}

قال النووي : إنما طلقها لأنه ظن أن اللعان لا يحرمها عليه فأراد تحريمها بالطلاق فقال هي طالق ثلاثاً فقال له النبي [ لا سبيل لك عليها ] أي لا ملك لك عليها فلا يقع طلاقك فئ

وهذا دليل على أن الفرقة تحصل بنفس اللعان (1) وقال الصنعاني : إن طلاق الملاعن ليس طلاقاً في محله ؛ لأنها بانت

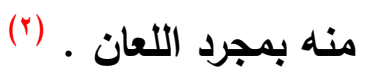

أما المسألة الثاتية : وهى الطلاق ثُلاثاً بلفظ واحد سني أم بلدعي

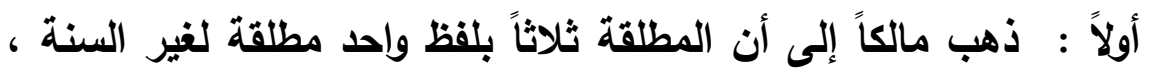
وذهب الثافعي إنه مطلق للسنة ، ويرجع سبب الخلاف إلى معارضة إقراره النبي الطلقة الثالثة فما ورد في القرآن من أن \}الطلاق مرتان

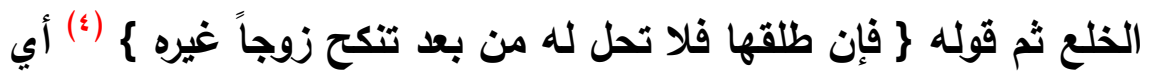
الطلقة الثالثة دلل على أن الطلقة الأولى والثانية كل منهما يعقبها رجعة ثم إن طلقها الثالثة فلا تحل له من بعد حتى تنكح زوجاً غيره ، وإذا كان هذا هو الأصل في الطلاق فإذا أوقع الزوج الطلاق ثُلاثاً مرة وإدة فهنا مخالف لما جاء في القرآن . وقال الشافعي لو كان بلدعة لما أقره الرسول

(1) شرح النووي على صحيح مسلم • 1 / r r I كتاب اللعان ور اجع التمهيد

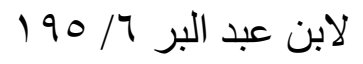

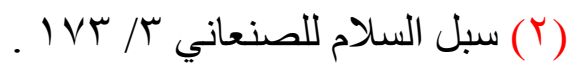

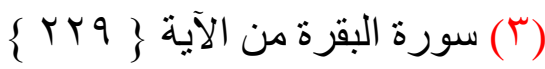

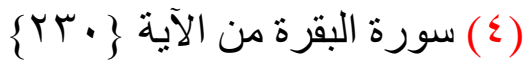




\section{السنة التقريرية كصدر من مصادر التثريع}

وقال النووي واستدل بطلاق العجلاني أصحابنا على أن جمع الطلقات

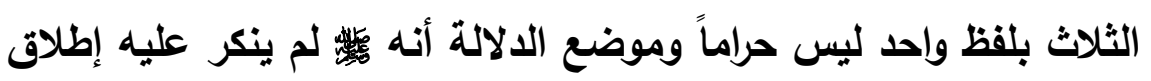

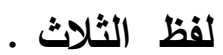

$$
\text { وقد يعترض على هذا : }
$$

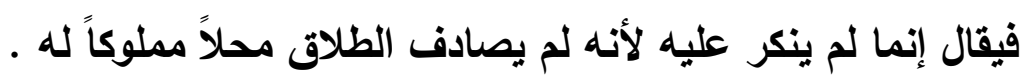

$$
\text { ويجاب عن هذا الاعتراض بأنه : لأنها }
$$

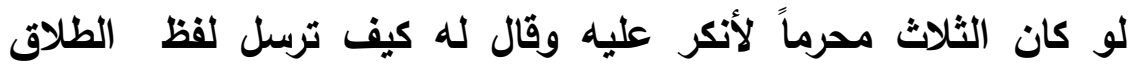

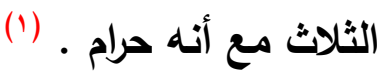
وأما مالك فقد اعتبر أن المطلق بلفظ الثلاث رافع للرخصة التي جعلها الله

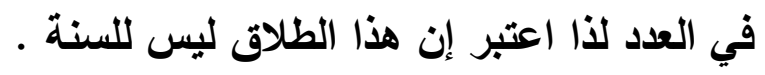
واعتذر أصحابه عن الحديث بأن المتلاعنين عنده قد وقعت الفرقة بينهما

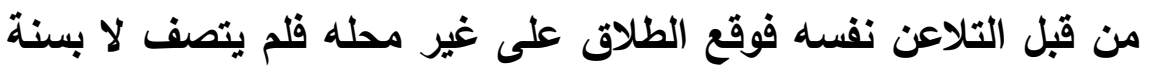
ولا ببدعة . من فئل

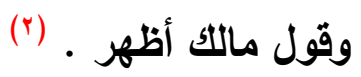
ثانياً : الطلاق ثلاثاً بلفظ واحد هل يقع طلقة واحدة أم يقع ثُلاثاً

فذهب الإمامية إلى أنه لا يقع به شيء لأنه بدعة وكل عمل ليس عليه

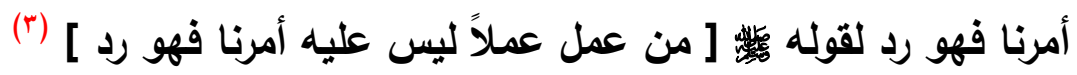
(1) شرح النووي على صحيح مسلم · / / r ا كتاب اللعان ط دار إحباء

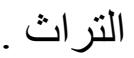

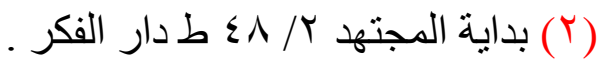

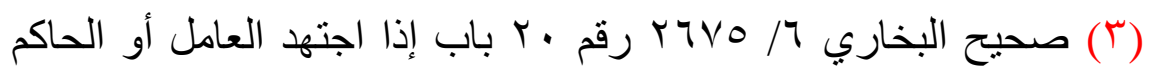

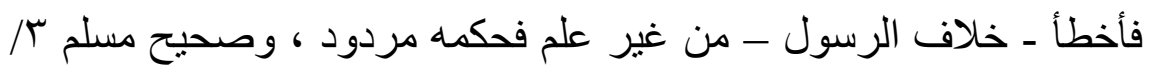

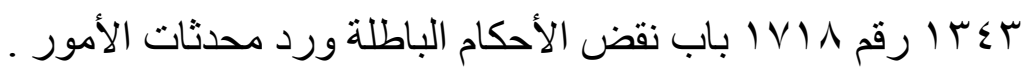




\section{دكتورة/ بثينة رشاد محمود}

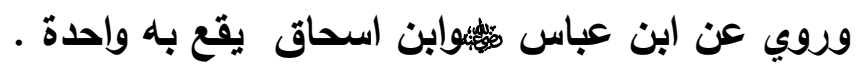

وقال طاوس وعكرمة : خالف السنة فيرد إلى السنة (1)

وذهب جمهور الصحابة وإلتابعين ومن بعدهم من أئمة المسلمين إلى أنه يقع ثلاث ومن الأدلة على ذلك ما ورد في سنن أبي داود عن مجاهد قال ( كنت عند ابن عباس فجاءه رجل فقال إنه طلق امرأته ثلاثاً قال فسكت حتى ظنتت أنه رادها ، ثم قال أيطلق أحدكم فيركب الحموقة ثم يقول يا ابن عباس يا ابن عباس ، فإن الله عز وجل قال \} ومن يتق الله يجعل له

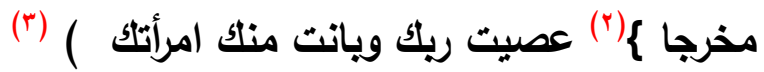
وأما ما ورد من أن عمر هناه. أمضى الطلاق الثلاث على من قالها ، فلا يمكن مع عدم مخالفة الصحابة له مع علمه بأنها كانت تقع واحدة ، إلا

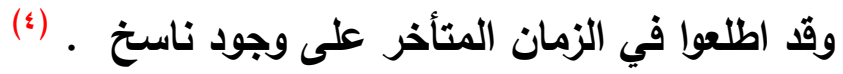

(1) شرح فتح القدير لكمال الدين السيو اسي ب/ ع ـ ـ دار الفكر .

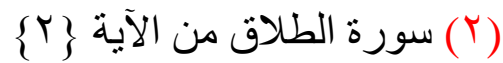

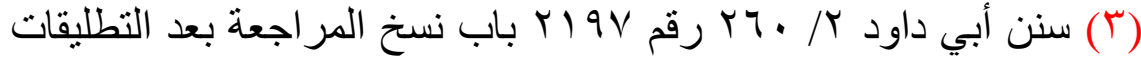

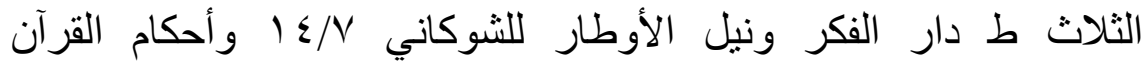

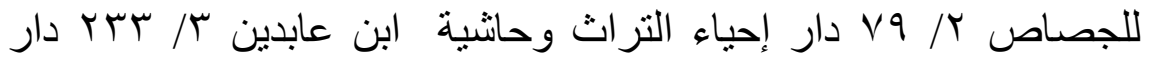

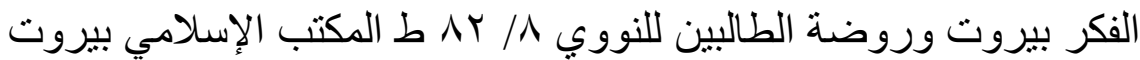

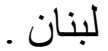
( ) شرح فتح القدير س/ • • شع دار الفكر . 


\section{السنة التقريرية كمصدر من مصادر التثريع}

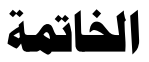

نخلص مما سبق إلى ما يلي

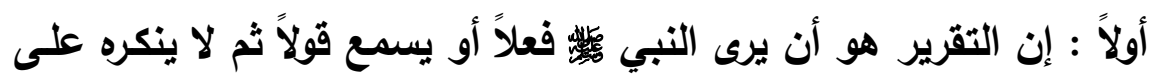

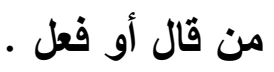

ثانياً : اختلف في أنسه هل يختص التهل التقريـر بمن قرر لـه أم يعم سـائر المكلقين - البال

ثالثاً : واختلف كذلك في أنه هل يحمل التقرير على الإباحة أم الوجوب أم الندب أم لا يقضى بثيء ويتوقف حتى يرد بيان .

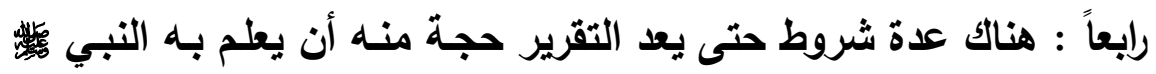

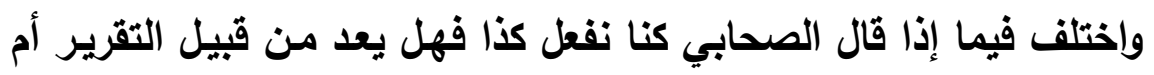

ومنها أن يكون قادراً على الإنكار ومنها كون المقر منقاداً للشرع إلى

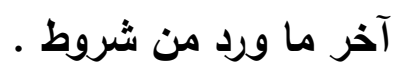

خامساً : للتقرير عدة صور يتحقق من خلالها.

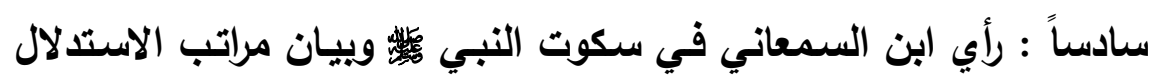

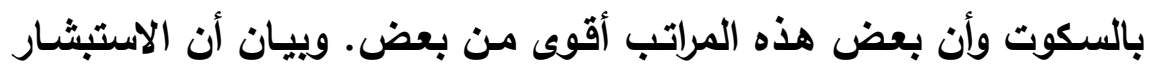

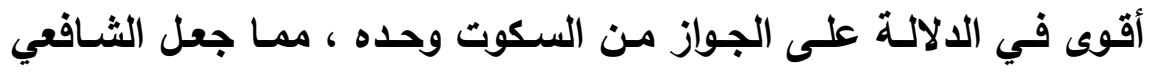
يتمسك به في إثبات القيافة .

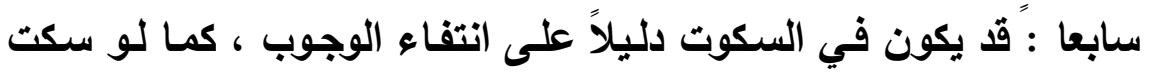

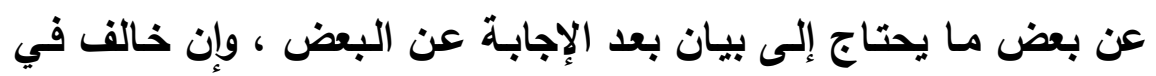
ذلك الحنفية . 


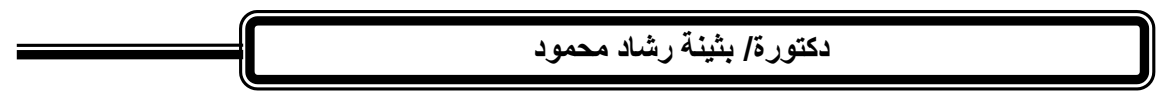

ثامنـاً : إن التقرير قد يكون مخصصـاً وإن لم يكن في المجلس اعتبره الحنفية ناسخاً .

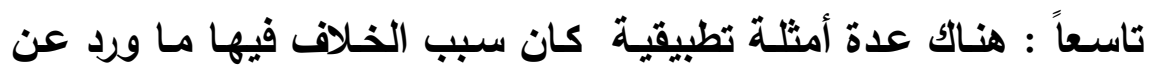
النبي 
السنة التقريرية كمصدر من مصادر التشريع

\title{
فهرس الموضوعات
}

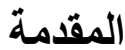 \\ خطة البحث \\ معنى تقرير النبي \\ محل الاتفاق \\ ومحل الاختلاف \\ شروط حجية التقرير \\ صور التقرير \\ أحكام سكوته \\ مراتب الاستـلال بالسكوت \\ حكم ما استحسنه
}

حكم السكوت عن بعض ما يحتاج إلى بيان بعد الإجابة عن البعض حكم التخصيص بالتقرير ما يتفرع على تخصيص العام بالتقرير ثمرة الخلاف حكم العزل حكم صلاة ركعتين بعد غروب الشمس حكم إخراج زكاة الخيل حكم وجوب الكفارة على المرأة المطاوعة في نهار رمضان الطلاق ثلاثاً بعد اللعان الطلاق ثلاثاً بلفظ واحد سني أم بدعي الطلاق ثلاثاً بلفظ واحد هل يقع ثلاثاً ؟ 

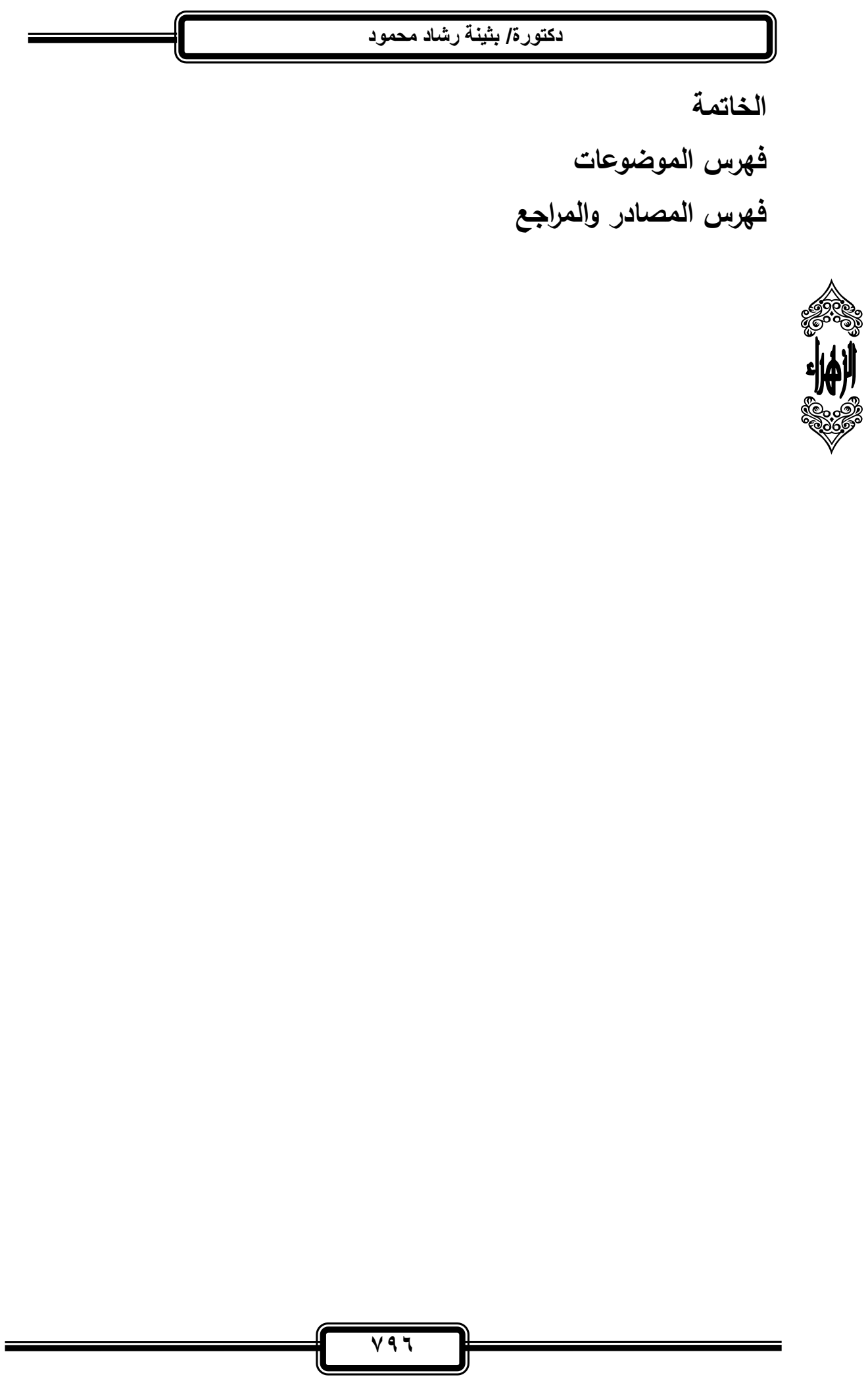


\section{السنة التقريرية كمصدر من مصادر التثريع}

\section{فهرس المراجع}

1- الإبهاج لابن السبكي دار الكتب العلمية بيروت

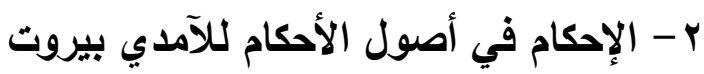

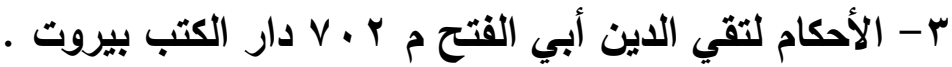

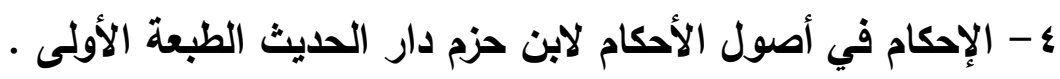

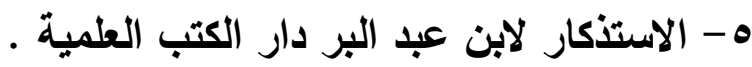

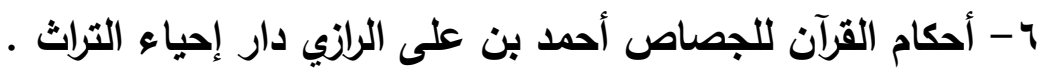

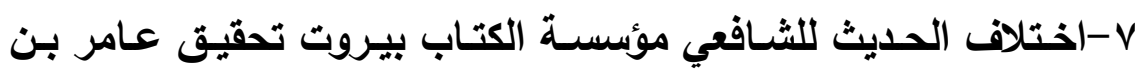

حيدر ط المار

1- إرثاد الفحول إلى تحقيق الحق من علم الأصول لمحمد على محمد

$$
\text { الثوكاني دار السلام }
$$

9 - إعلام الموقعين عن رب العالمين لابن القيم طبعة دار الجيل بيروت .

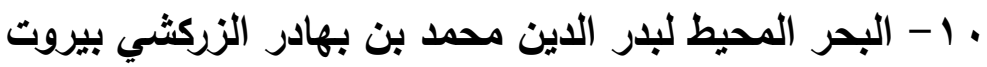

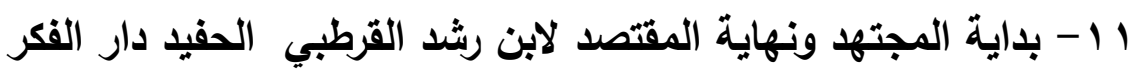

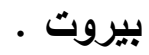

r ا I - البرهـان لإمـام الحرمين أبي المعالي بن عبد الملك الجويني دار

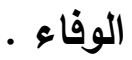

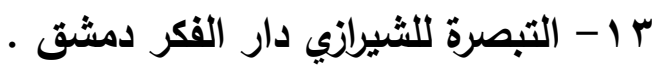

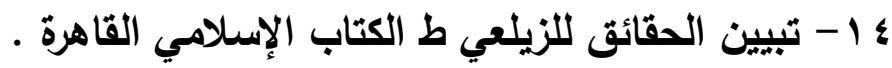

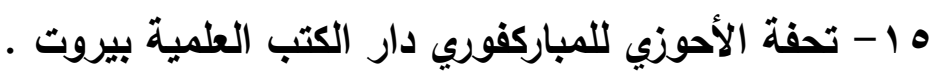
17 - 19 IV

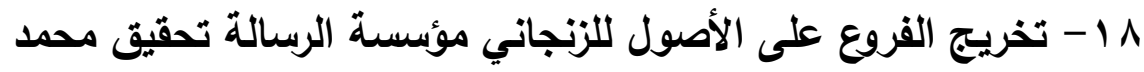

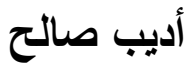


9 ا - تذكرة المحتاج إلى أحاديث المنهاج لابن الملقن تحقيق حمدي عبد

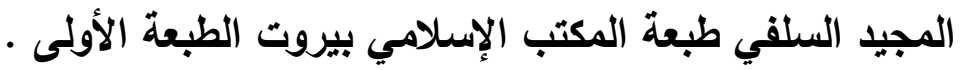
• r - التعريفات للجرجاني دار الريان

ا Y - التقريز والتحبير لابن أمير حاج الحلبي دار الفكر بيروت التبان

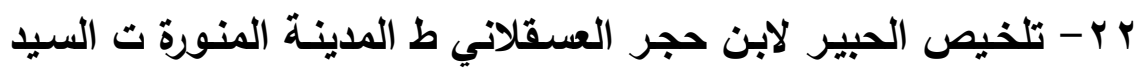
عبد الله هاشم اليماني r - التمهيد لابن عبد البر وزارة عموم الأوقاف تحقيق مصطفى العلوي ومحمد البكري

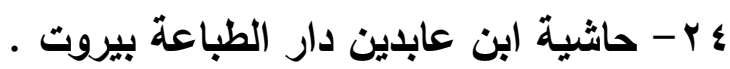

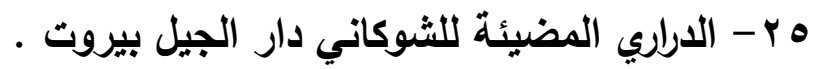

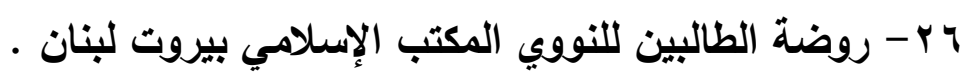

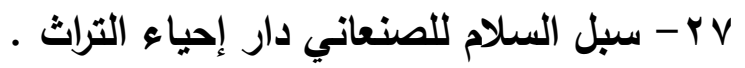

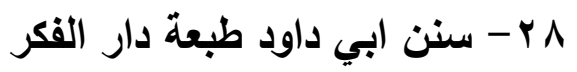

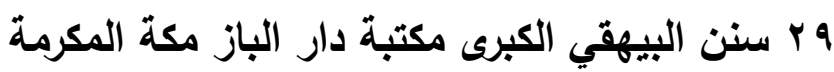

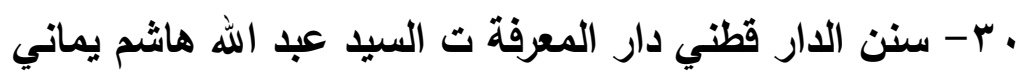

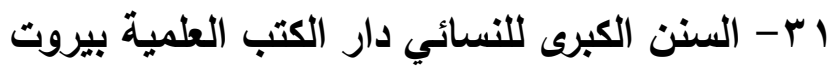
r r - سنن ابن ماجة طبعة دار الفكر .

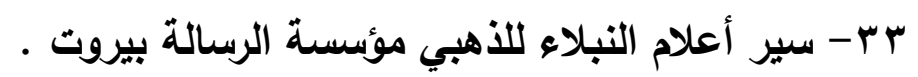

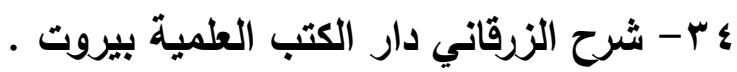

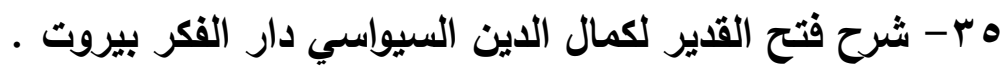
ب - شرح النووي على صحيح مسلم دار إحياء التراث N

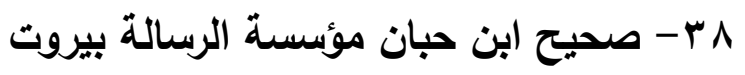

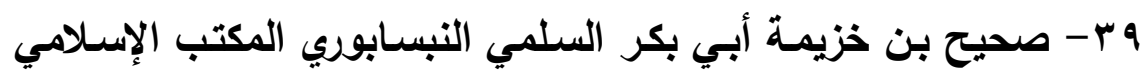

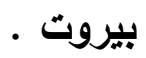




\section{السنة التقريرية كمدر من مصادر التثريع}

• ـ - صحيح مسلم دار إحياء التراث .

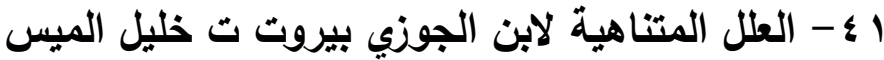

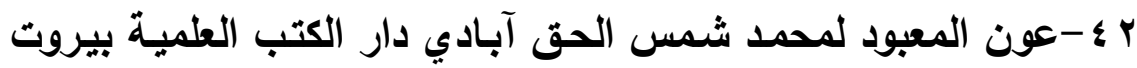

ابنان ط أعرة

ب ؟ - الغرة المنيفة لأبي حفص الغزنوي الحنفي طبعة بيروت

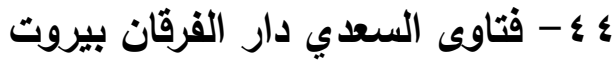

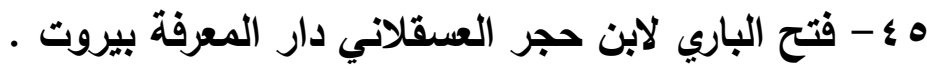

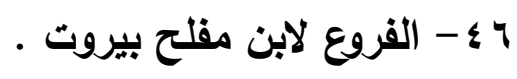

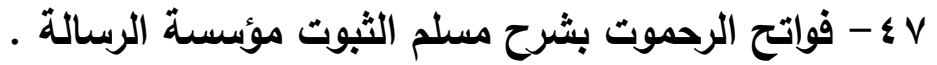

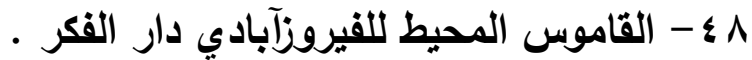

9 § - قواطع الأدلة لأبي المظفر ابن السمعاني دار الكتب العلمية بيروت.

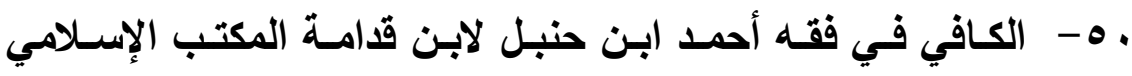

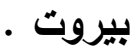

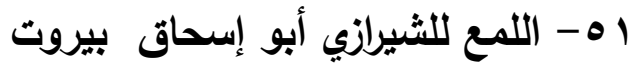

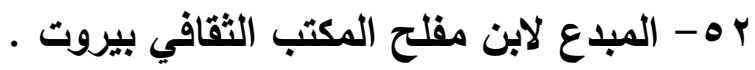
به - المبسوط للسرخسي دار المعرفة

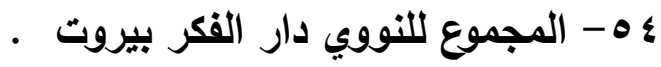
هـ - المحصول للفخر الزرازي من النفائس بيروت.

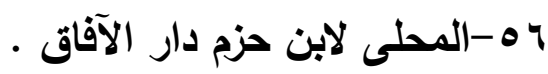

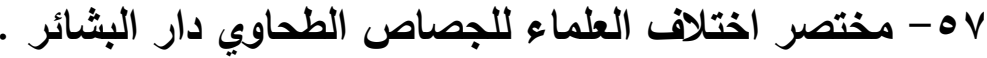

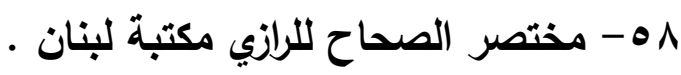

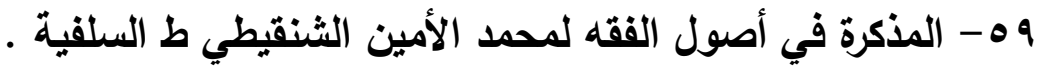
ـ ؟- المستدرك على الصحيحين للحاكم النيسابوري دار الكتب العلميـة

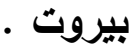

1آ- المستصفى للغزالي دار الكتب بيروت ت محمد عبد السلام . 


\section{دكتورة/ بثينة رشاد محمود}

r

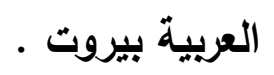

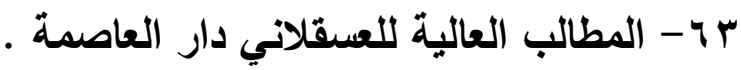

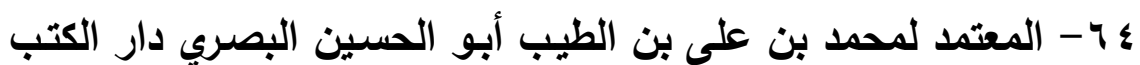
العلمية بيروت ت خليل الميس.

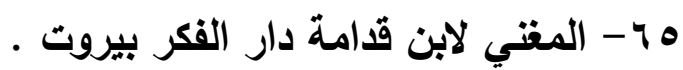

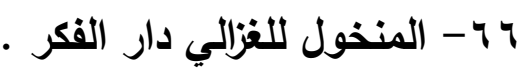
Vا - نزهة الخاطر العاطر لعبد القادر الدمشقي على روضة الناظر لابن

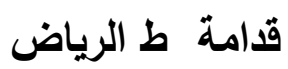
1 - - نصب الراية للزيلعي دار الحديث . 9 ૧ - نفائس الأصول في شرح المحصول للقرافي شهاب الدين الصنهاجي

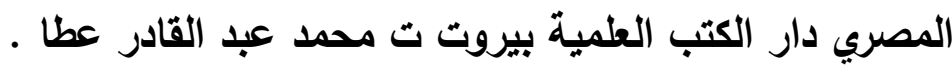

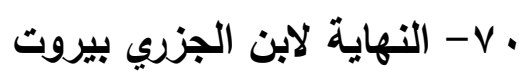

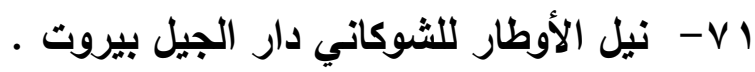
تم بحمد الله في الرابع عثر من

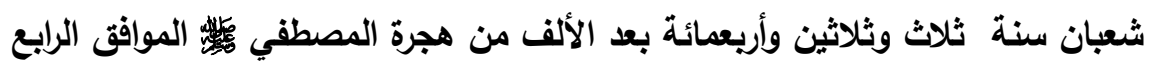

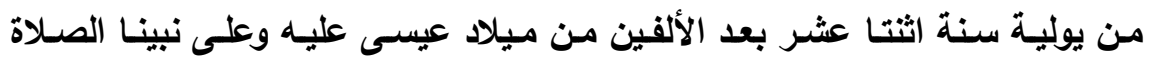

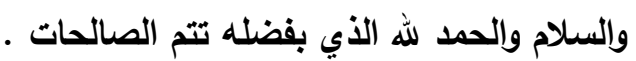

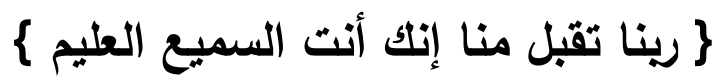

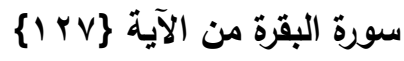

دكتورة / بثينة رشاد محمود الابة ربور 